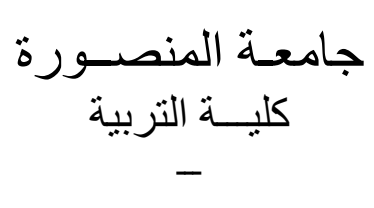

\title{
واقع همهارسة إدارة المواهب المؤسسية لدى قائدات المدارس الثانوية بمنطقة جازان
}

\author{
إعداد \\ الباحثة/ عهود بنت يحي علي بحاري \\ إثنر افت \\ أ.د / أحمد عبد القادر سعد الدين

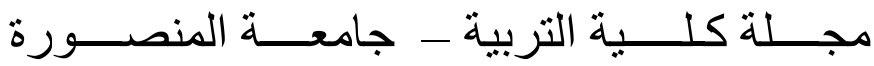

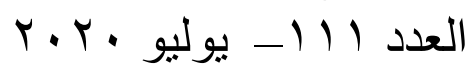




\section{و اقع ممارسة إدارة المو اهب المؤسسية لدى قائدات المدارس

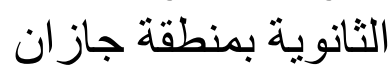

\section{عهود بنت يحي علي بحاري}

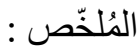

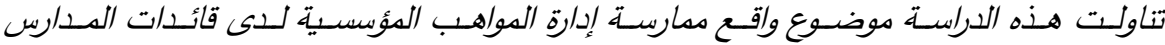

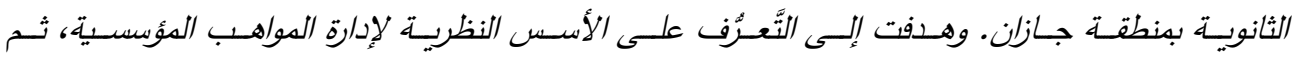

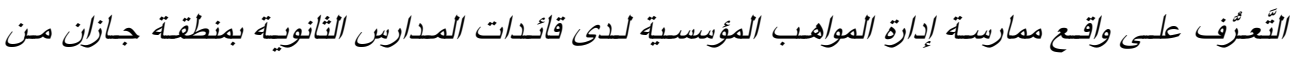

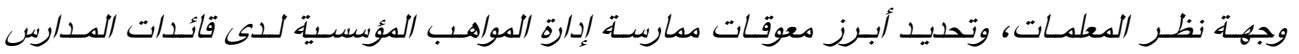

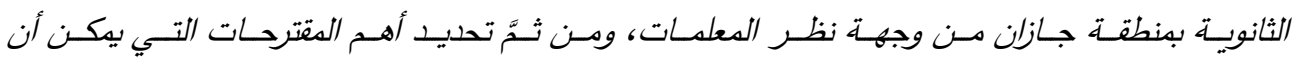

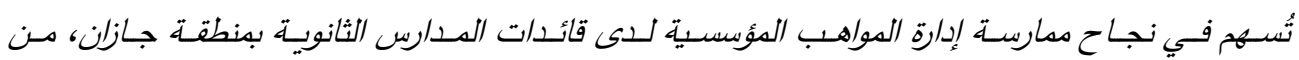

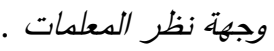

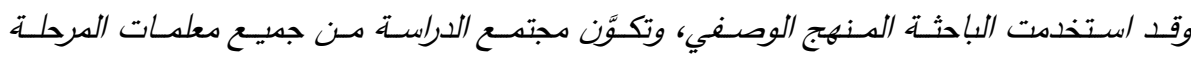

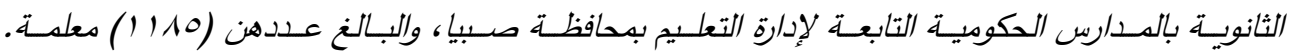

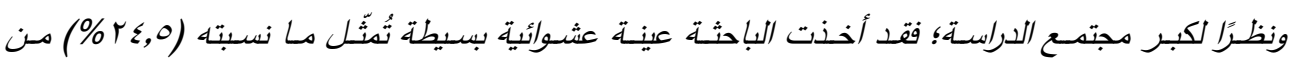

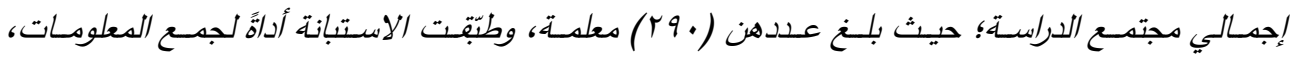
وتمَّت معالجة بيانات الدراسة باستخدام برنامج (SPSS)

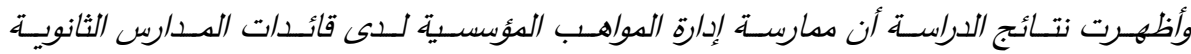

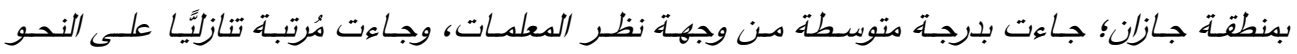

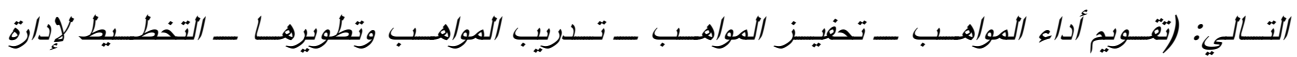

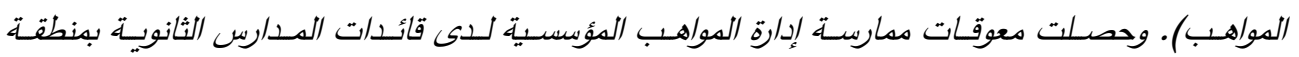

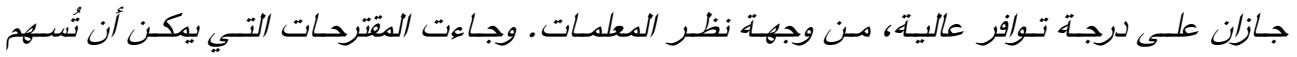

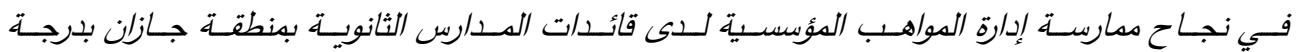

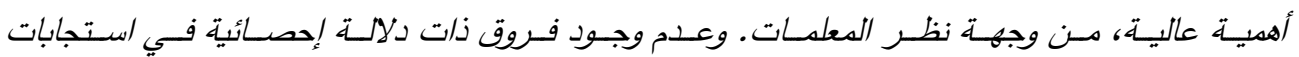

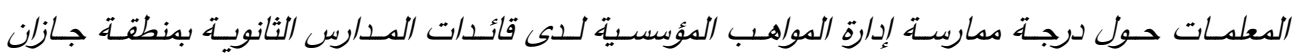
بجميع أبعادها، باختلاف متغيري: (المؤهل العلمي، وعدد سنوات الدئ الخبرة).

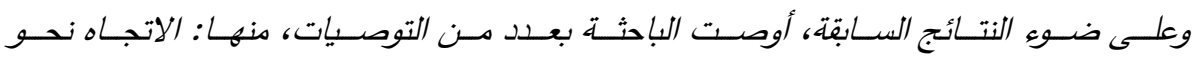

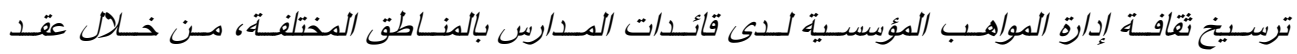

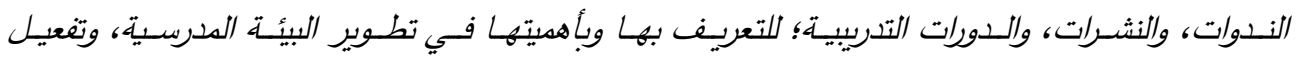

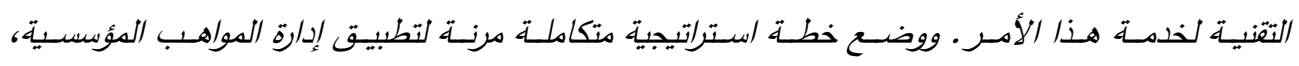




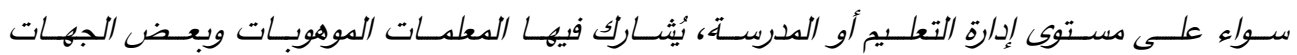

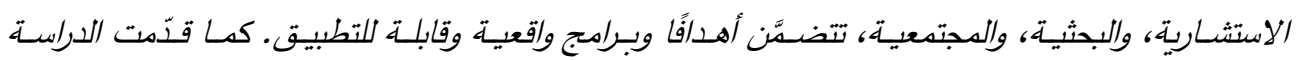

$$
\text { مُقترحات لدراسات مستقبلية. }
$$

\section{Abstract}

This study aims at recognizing the reality of institutional talent management among female secondary school leaders in Jazan through studying the theoretical bases of talent management, as well as conducting a field study to know the reality of institutional talent management from the points of view of school teachers. The study also aims at recognizing the statistically significant differences among the mean scores of the sample regarding the study variables (type of qualification and years of experience), in addition to the understanding of the obstacles that hinder the practice of talent management among female secondary school leaders in Jazan. The study uses the descriptive method through a questionnaire on a sample of (290) female secondary school teachers in Sabia Directorate of Education, which represents (24.5\%) of a total number of (1185) teachers. Sample responses have been analyzed using SPSS.

Study findings show that the level of practicing institutional talent management is intermediate among female secondary school leaders, and such practices can be arranged descendingly as talent performance evaluation, talent motivating, talent training and improvement, and planning for talent management. There are no statistically significant differences among the mean scores of the sample regarding the variables (type of qualification and years of experience), while the obstacles facing the application of talent management are found to be high.

The study presents some recommendations such as the organization of meetings and training courses to raise the awareness of school leaders concerning the importance of talent management in improving the whole school environment, and setting up a whole strategic plan for the application of institutional talent management in schools and educational directorates.

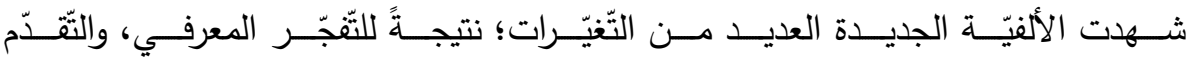

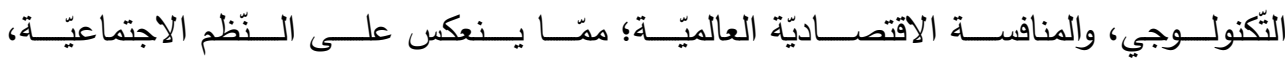

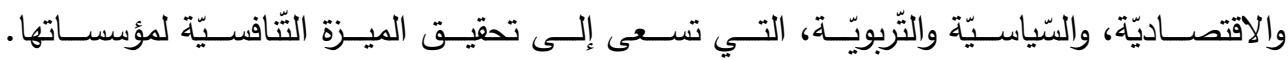

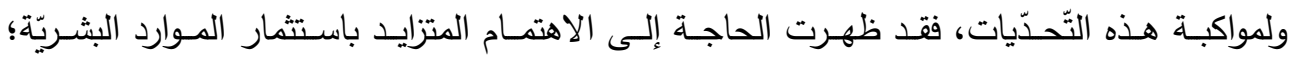




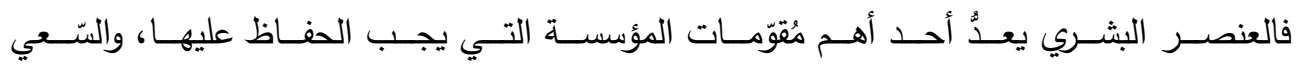
لتطويرها نحو تحقيق الأهداف المنشودة.

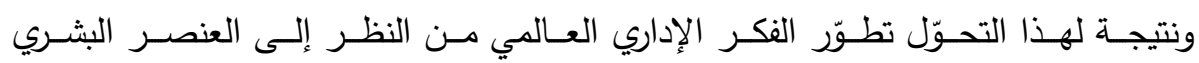

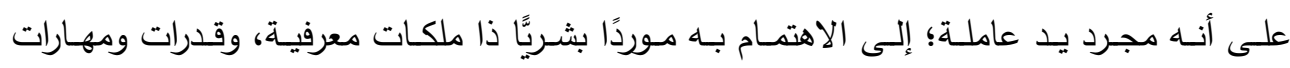

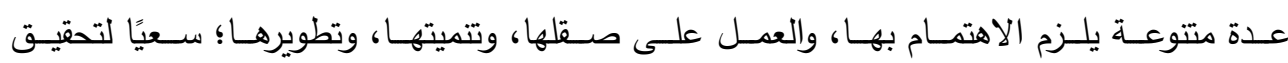

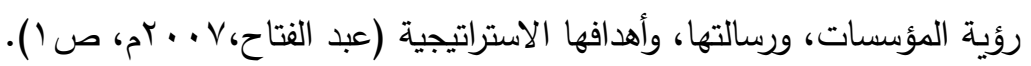

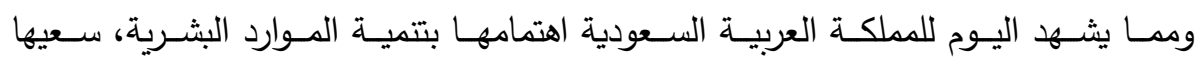

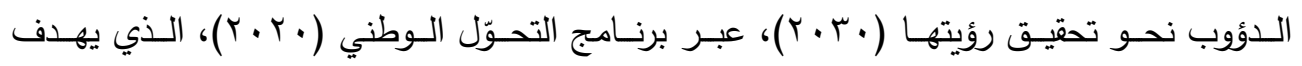

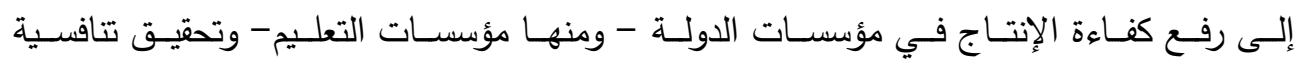

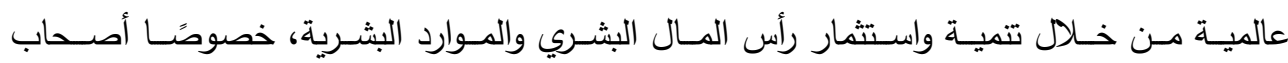

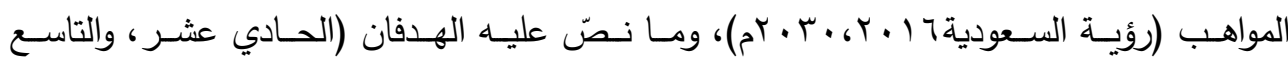

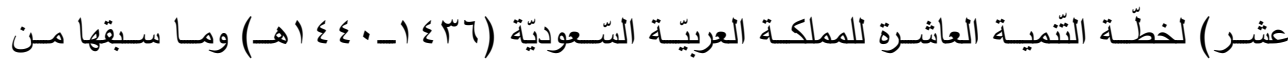

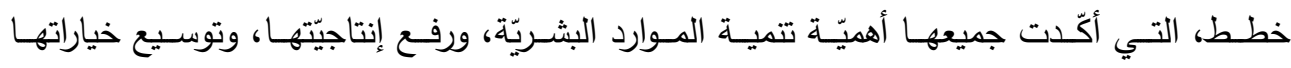

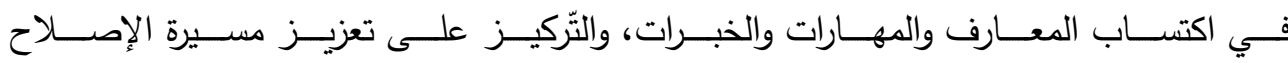

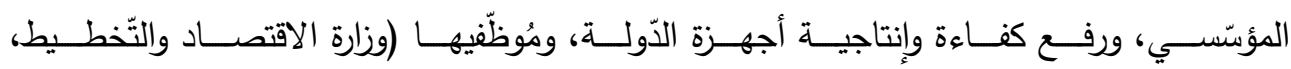

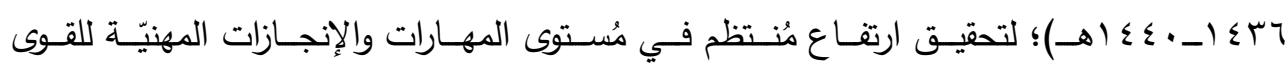
العاملة السّعوديّة.

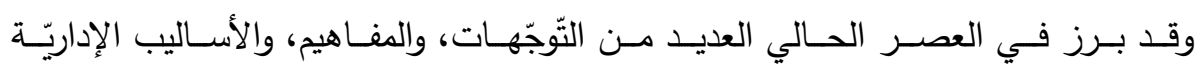

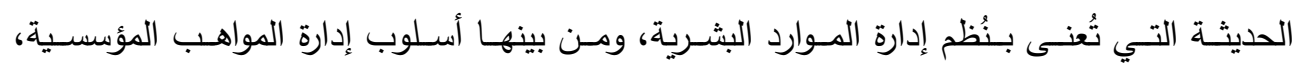

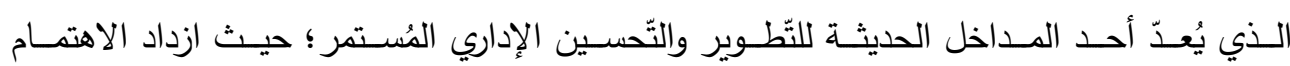

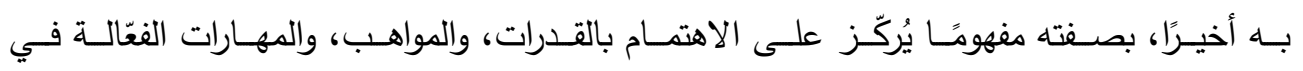

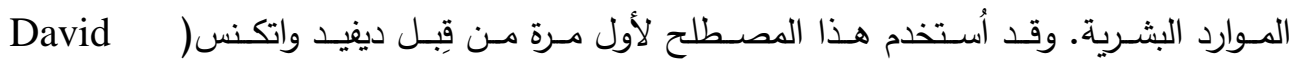

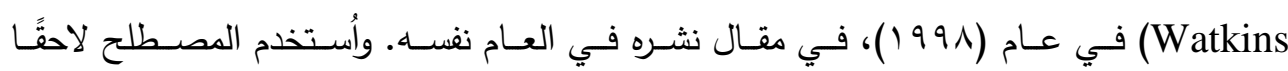

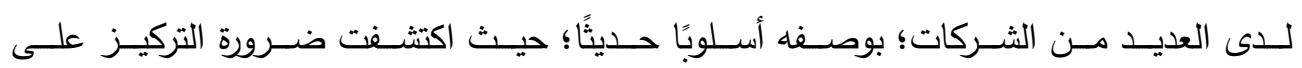

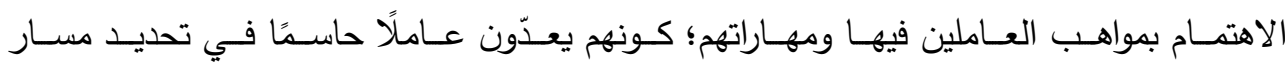

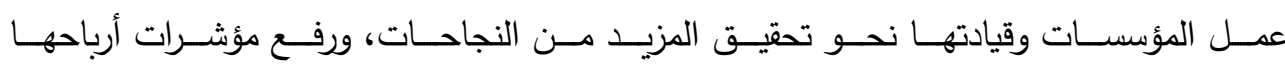

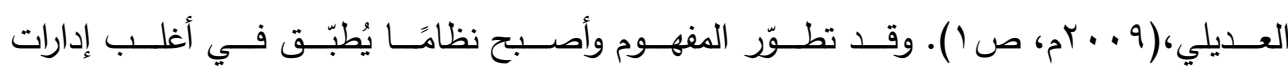




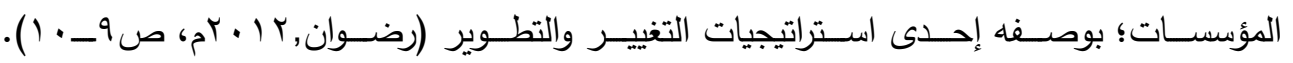

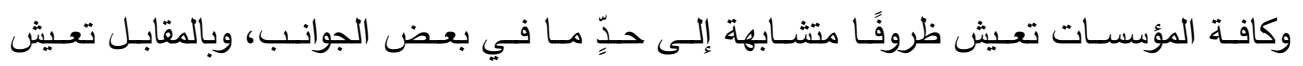

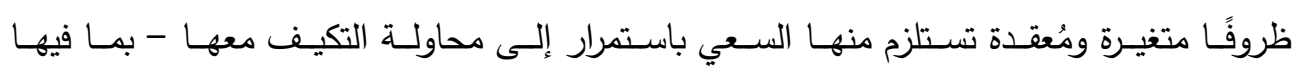
المؤسسات التعليمية- مما يجعل حاجتها إلى تطبيق إدارة المواهب المؤسسية حاجة مُلحة.

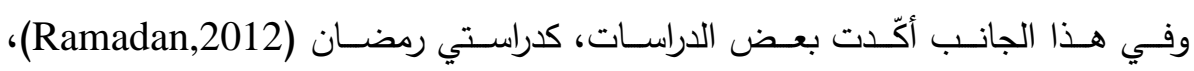

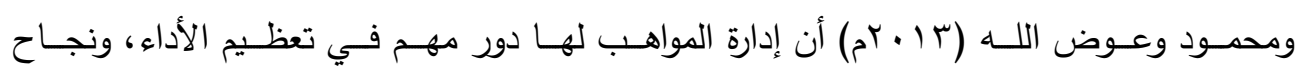

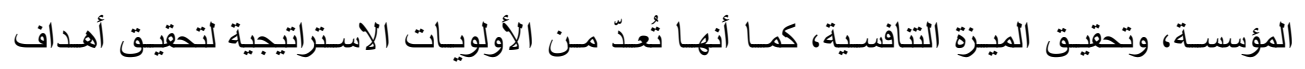

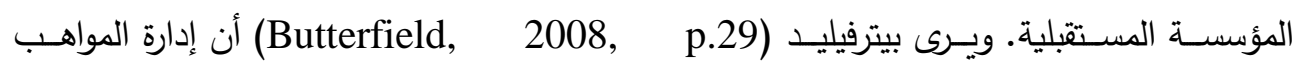

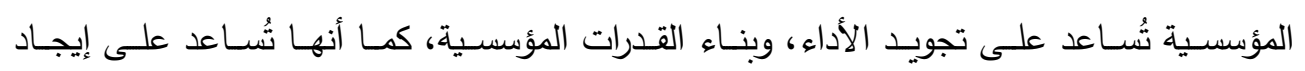

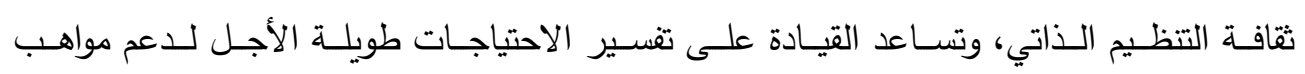
العاملين، والتي من شأنها تحقيق مستقبل التخطيط المؤسسي.

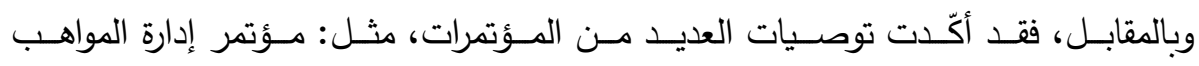

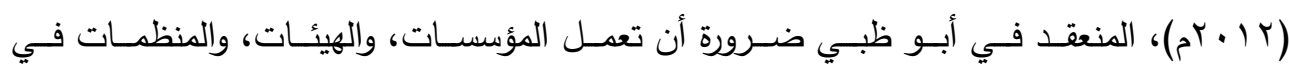

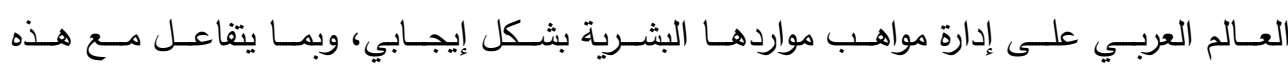

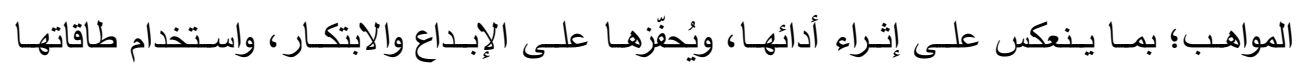
لتحقيق الميزة التتافسية.

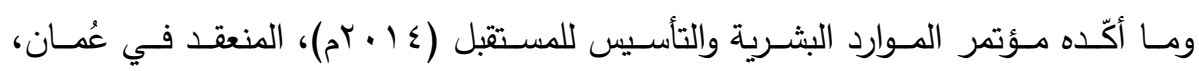

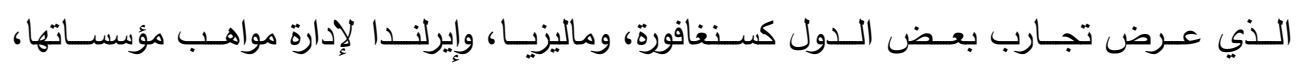

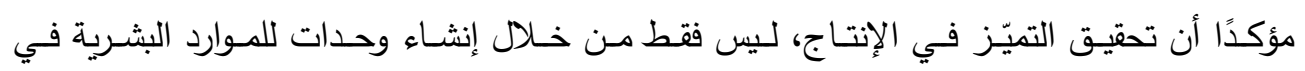

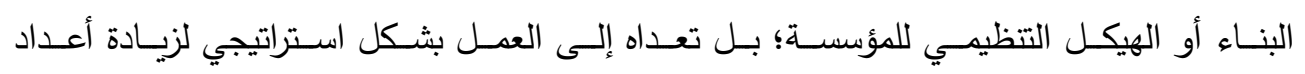

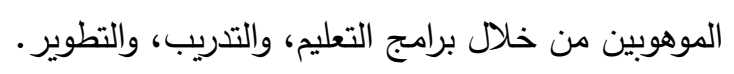

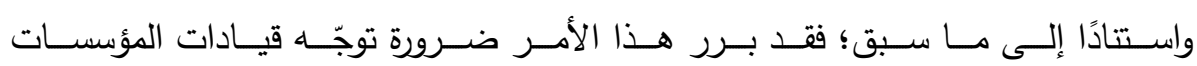

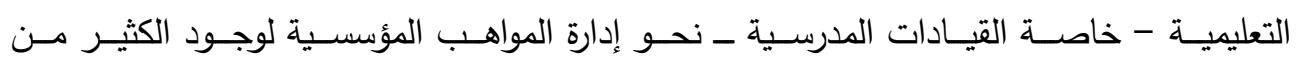

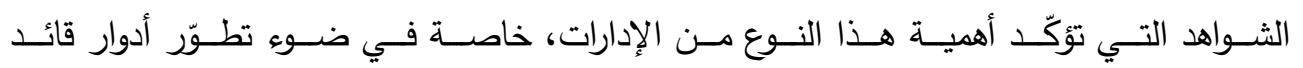

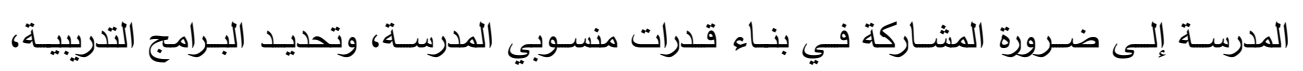

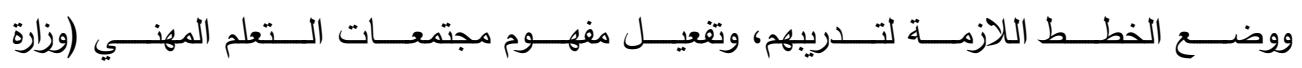

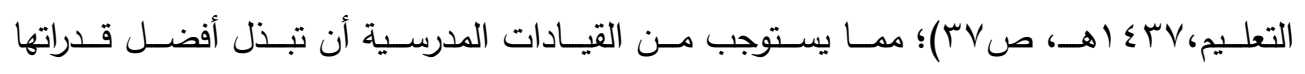


لإدارة مواهـب المعلمـات؛ مـن خـلال تبنـي ممارسـات إداريـة تُمكّن مـن اسـتثمارها علـى النحـو

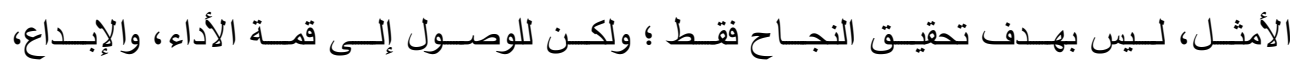
والإنجاز المُتميز؛ لمواكبة المتغيرات المتسارعة.

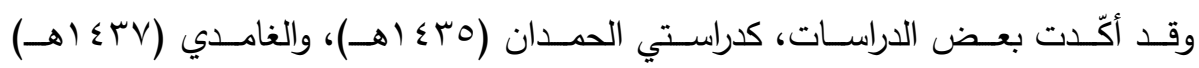

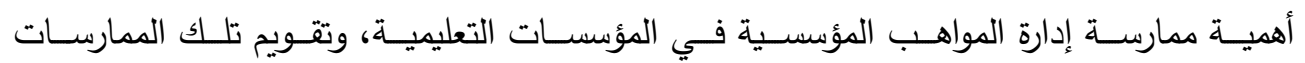

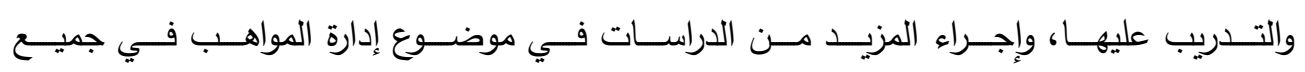

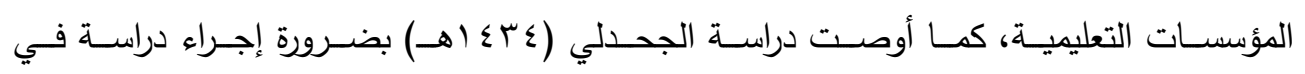
إدارة المواهب بالتعليم العام.

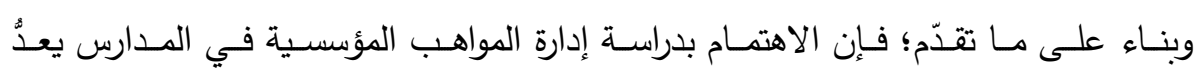

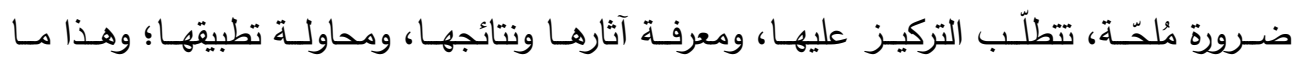
سعت إليه الدراسة الحالية. مشكلة الدر اسة:

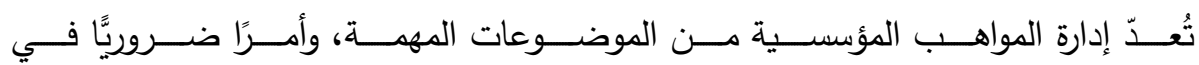

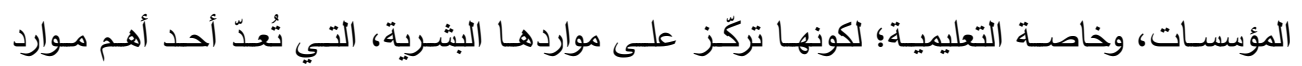

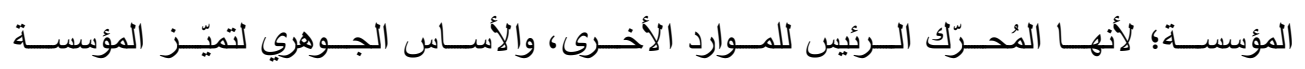

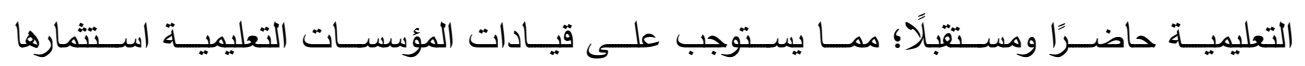
والاستفادة منها، من خلال إدارتها بشكل أفضل.

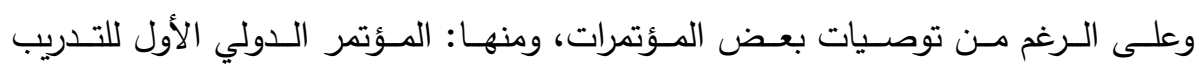

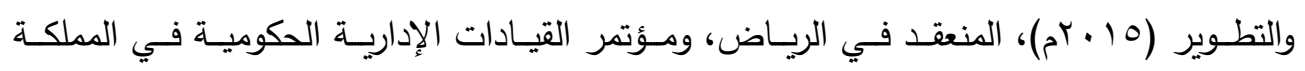

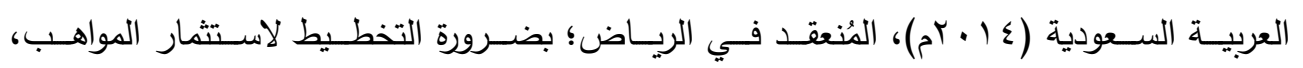

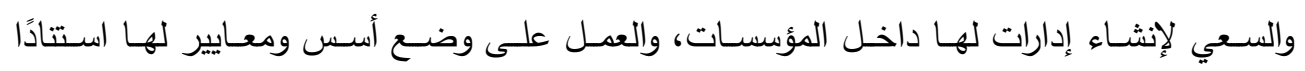

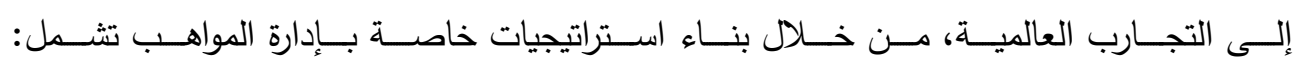

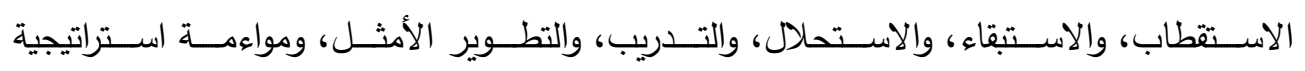

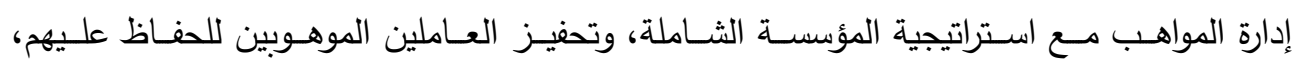

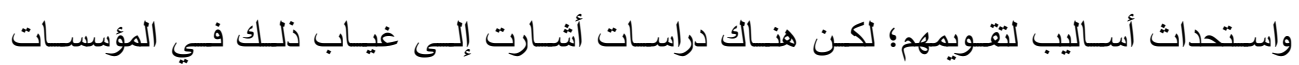

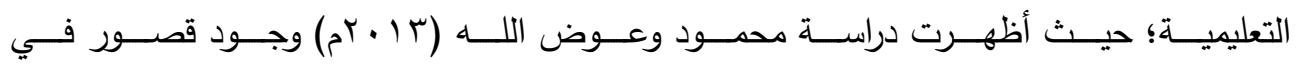

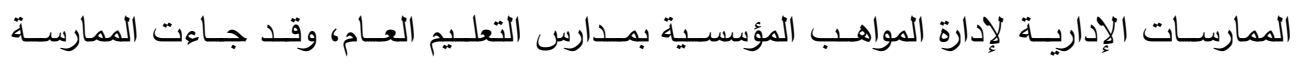




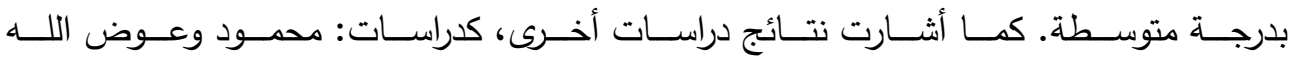

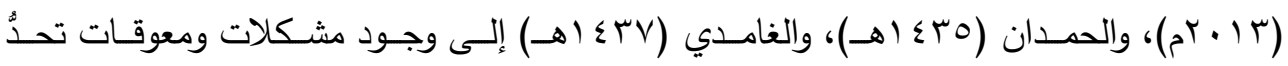

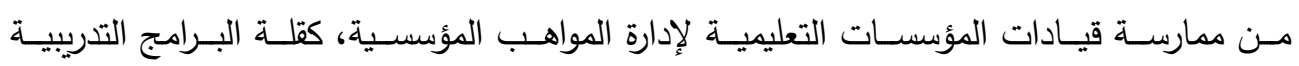

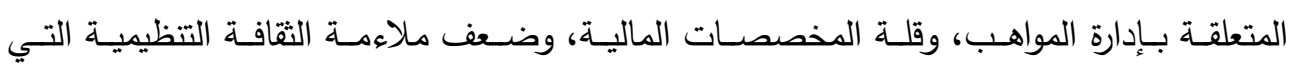

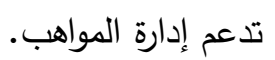

وبحسب علـم الباحثـة، وبحكم طبيعـة عملهـا معلمـة، واطلاعهـا على الميـدان التربـوي؛

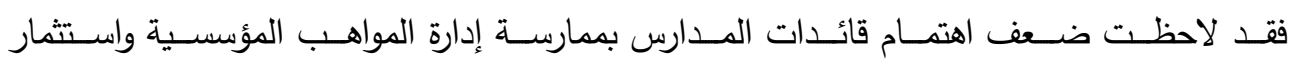

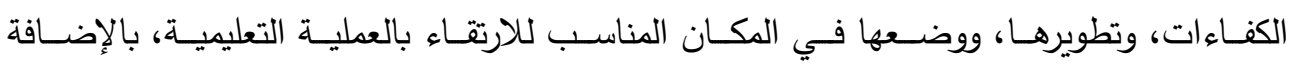

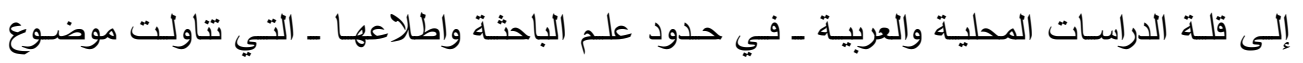

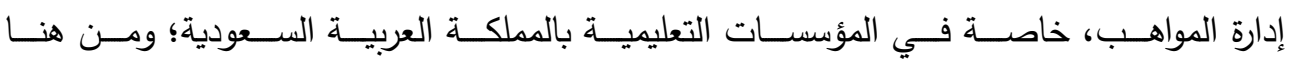

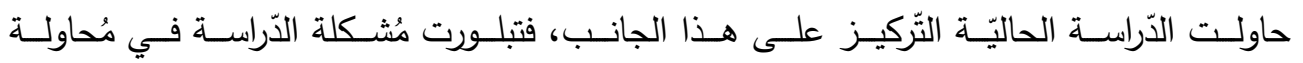

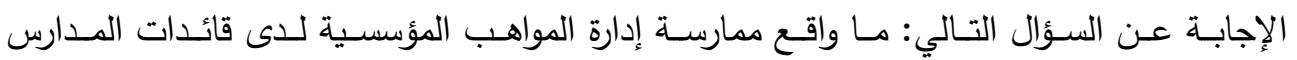

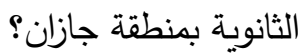

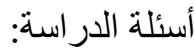
حاولت هذه الدراسة الإجابة عن الأسئلة التالية: ا ا. ما الأسس النظرية لإدارة المواهب المؤسسية؟ الأبنه

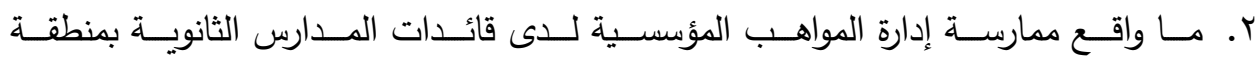
جازان، من وجهة نظر المعلمات؟

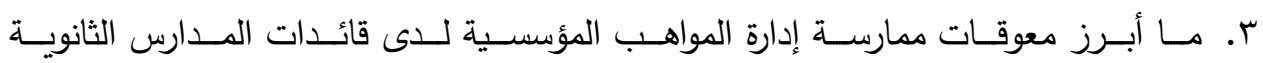
بمنطقة جازان، من وجهة نظر المعلمات؟

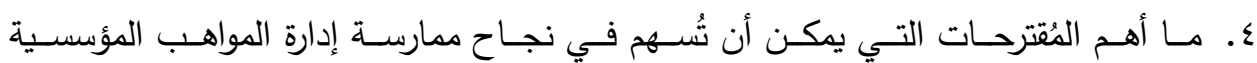
لاى قائدات المدارس الثانوية بمنطقة جازان، من وجهة نظر المعلمات؟

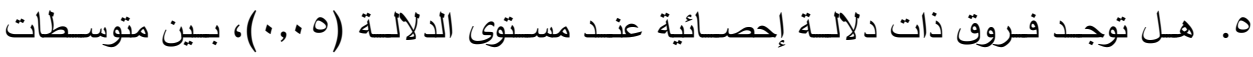

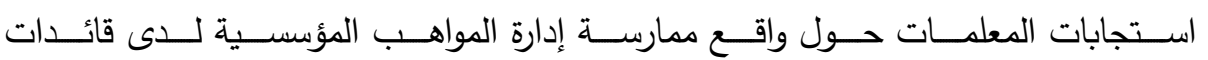
المــارس الثانويــة بمنطقـة جـازان؛ يمكـن أن تُعـزى إلـى أي مــن متغيـري: (المؤهـل

$$
\text { أهداف الدر اسئة: عدد سنوات الخبرة)؟ }
$$

سعت هذه الدراسة إلى تحقيق الأهداف التالية: 
ا ا. التَّرُفْ على الأسس النظرية لإدارة المواهب المؤسسية.

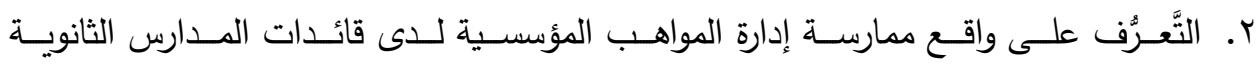
بمنطقة جازان، من وجهة نظر المعلمات.

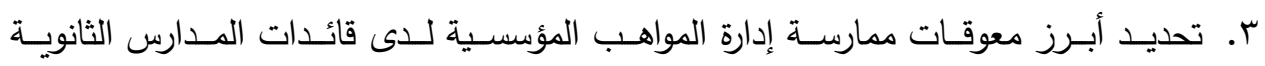
بمنطقة جازان، من وجهة نظر المعلمات.

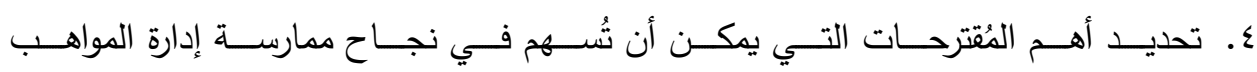
المؤسسية لدى قائدات المدارس الثانوية بمنطقة جازان، من وجهة نظر المعلمات. أهمية الدر اسة:

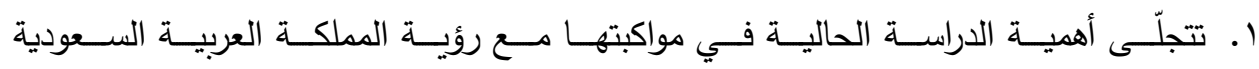

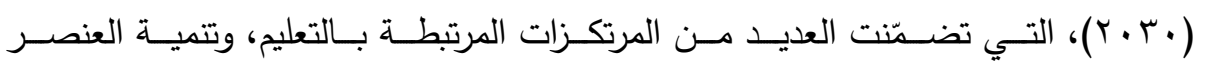

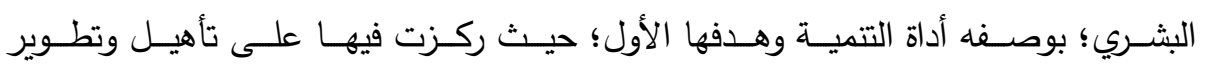
قدرات المعلمين والقيادات التربوية وتدريبهم.

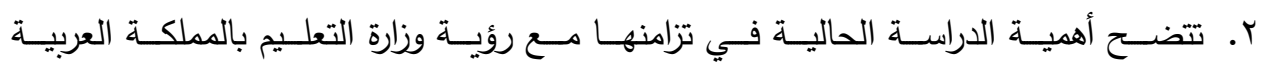

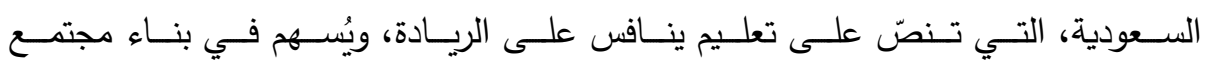

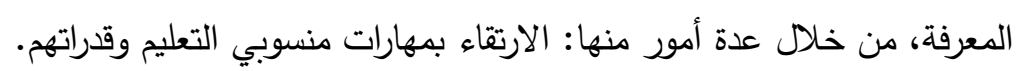

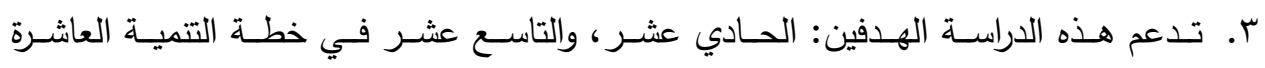

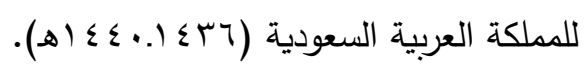

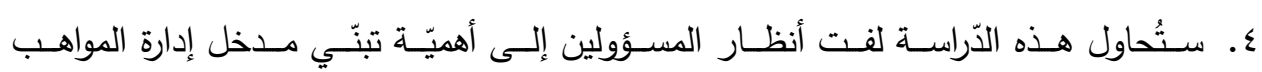

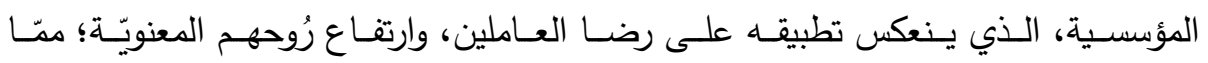
يُسهم لاحقًا في تحسين نوعية مخرجات الأداء، وزيادة كميّته.

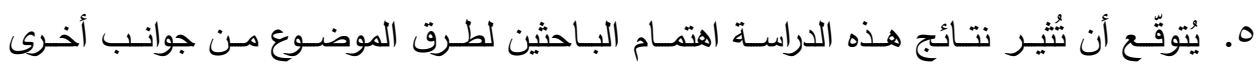
لم تشملها حدود الدراسة الحالية.

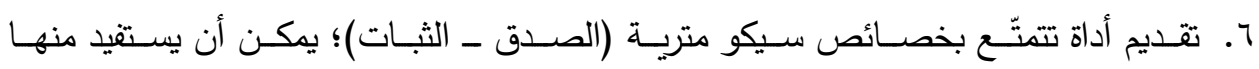

$$
\text { حدود الدر استة: }
$$

- الحـدود الموضـوعية: تحدّد موضـوع الدراسـة الحاليـة في بحثث واقـع ممارســة إدارة المواهب

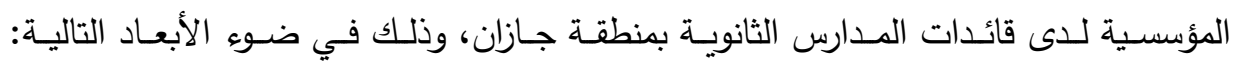

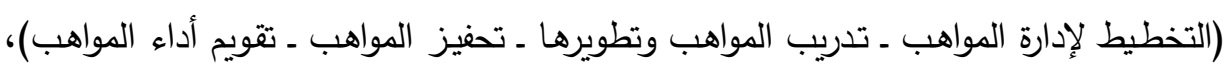


وتحديد أبرز معوقات ممارسة إدارة المواهب المؤسسية لدى قائدات المدارس الثانوية بمنطقة

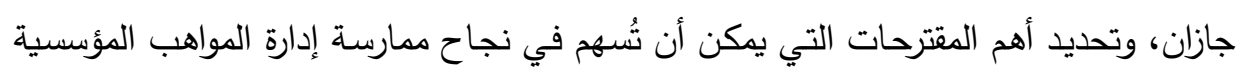

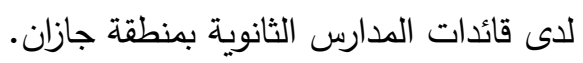

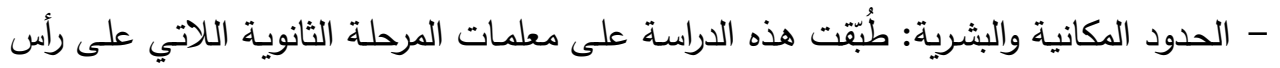

العمل في المدارس الثانوية الحكومية التابعة لإدارة التعليم بمحافظة صبيدا.

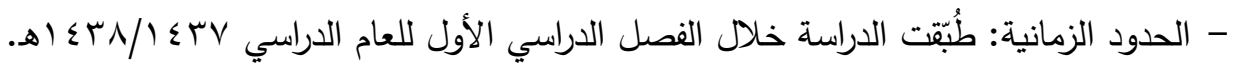
مصطلحات الدر اسة:

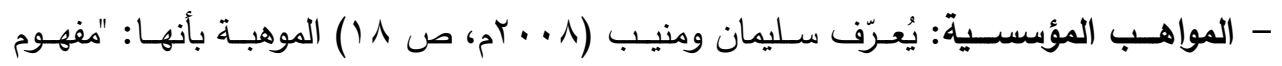

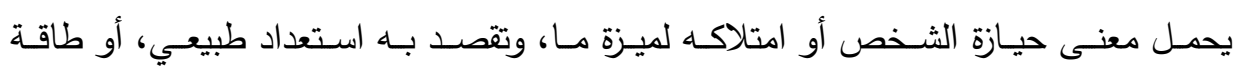

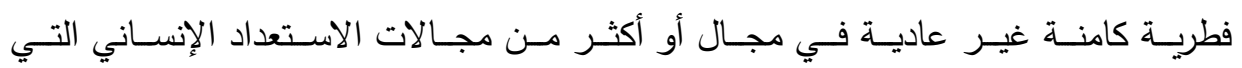

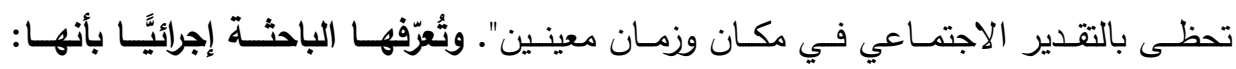

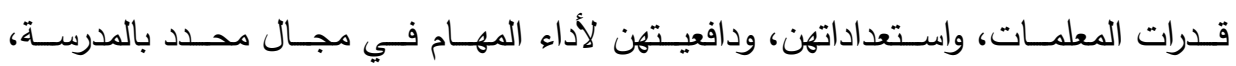
بطريقة مميزة مقارنة بأداء الأخريات.

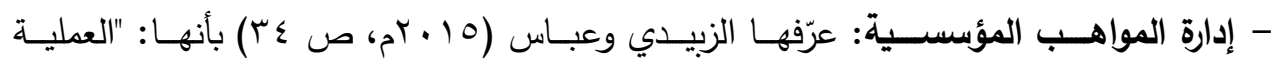

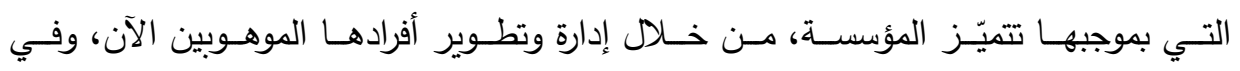

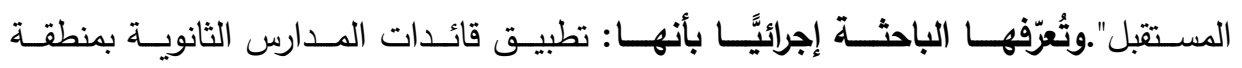

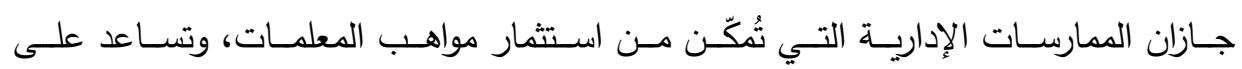
تحقيق أهداف المدرسة.

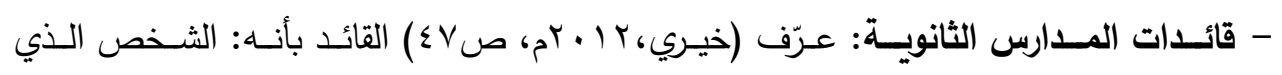

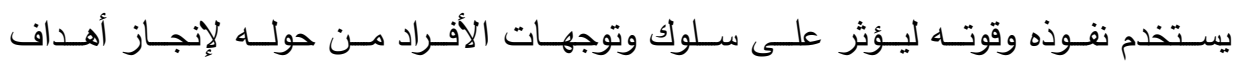

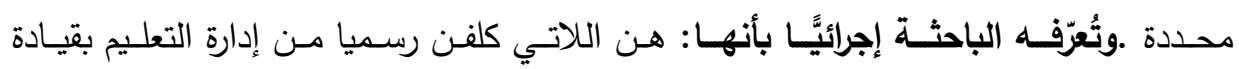

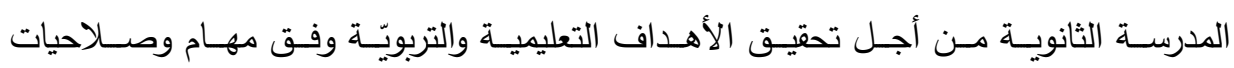
محددة.

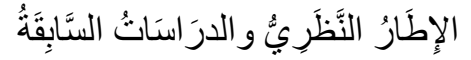
المبحث الأول: إدارة المواهب المؤسسية مفهوم الموهبة وإدارة المواهب المؤسسية:

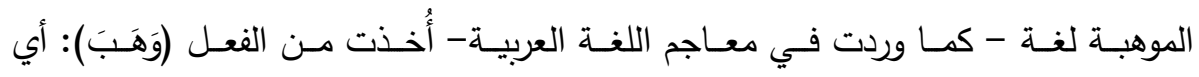

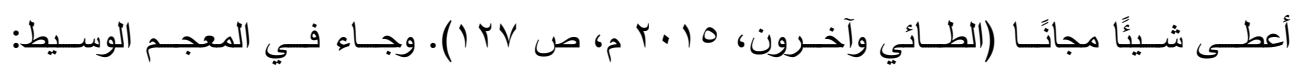




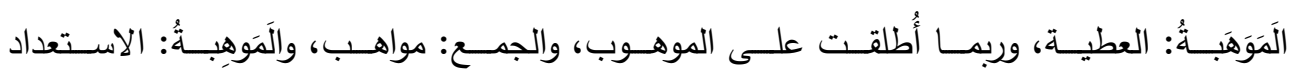

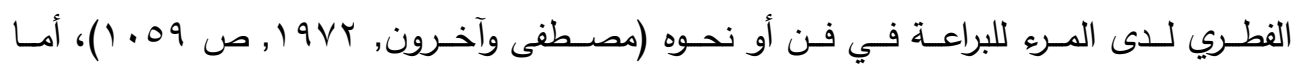

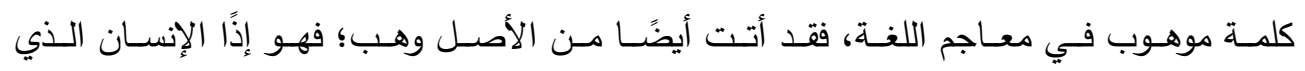

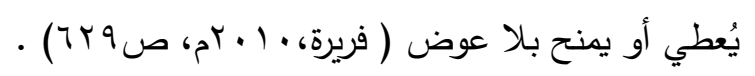

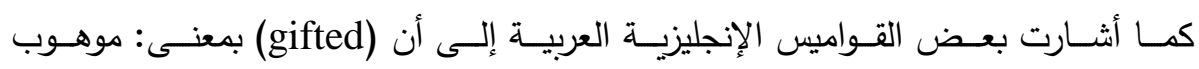

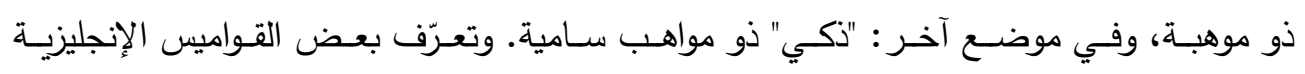

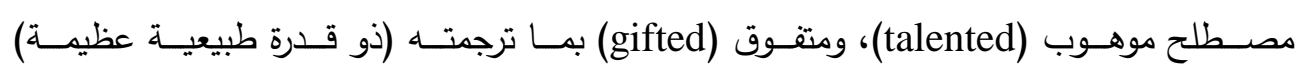

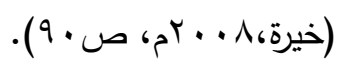

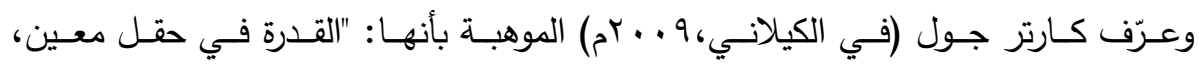

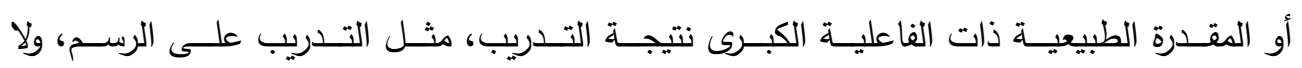

$$
\text { تشمل بالضرورة درجة كبيرة من الذكاء العام" (صؤ. }
$$

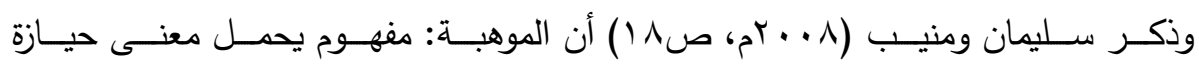

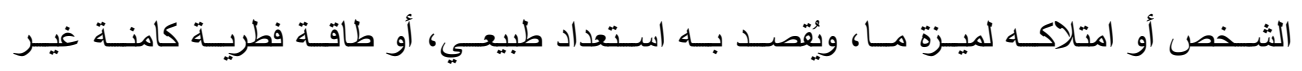

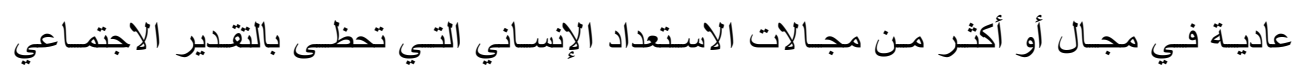

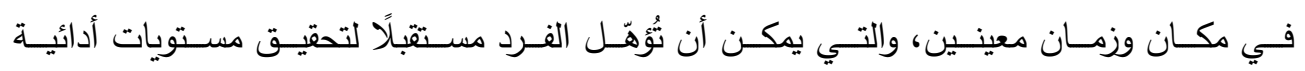

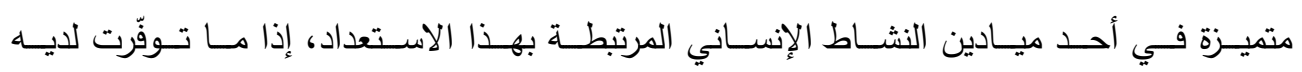
العوامل الثخصية والدافعية اللازمة، وتهيأت له الظروف البيئة المناسبة.

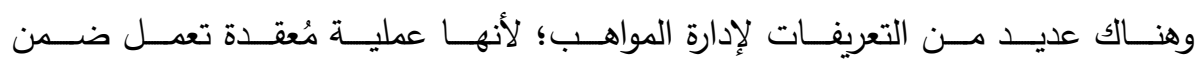

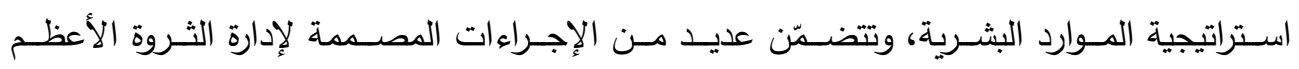

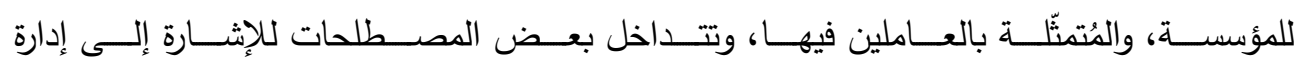

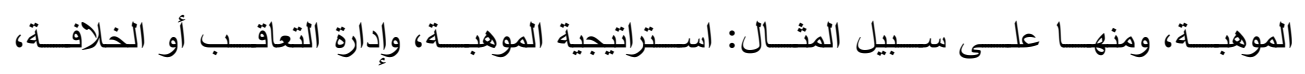

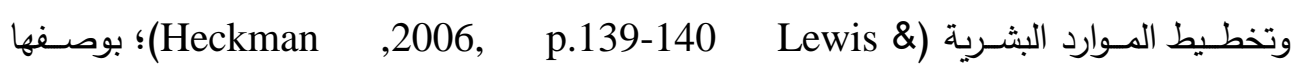

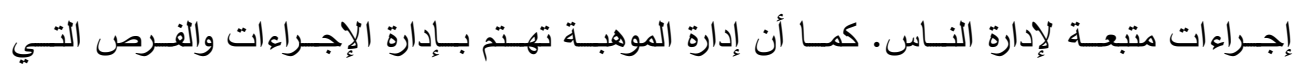

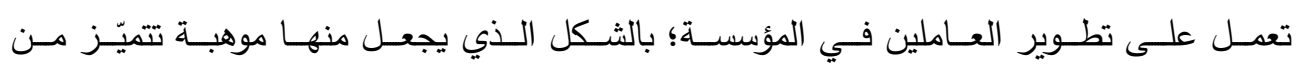

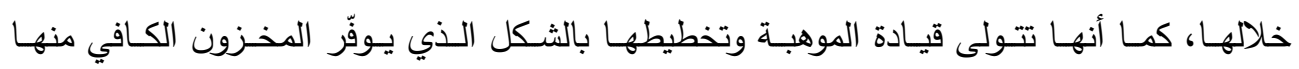

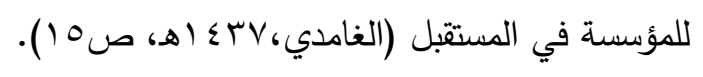


وفيمــا يـــي عـرض لــبعض التعريفــات المختلفـــة لبــاحثين وإداريــين لمفهــوم إدارة المواهب، كل حسب وجهة نظره:

عـرف كرستتسـن وروق (Christensen\&Rog,2008, p.744) إدارة المواهـبـ

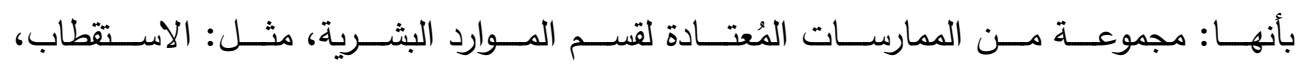

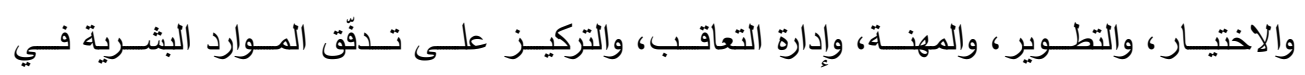

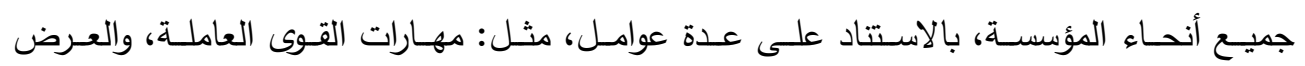
والطلب، والتركيز على المصادر، وتطوير موهبة العامل ومكافاتها.

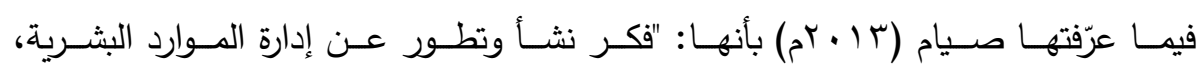

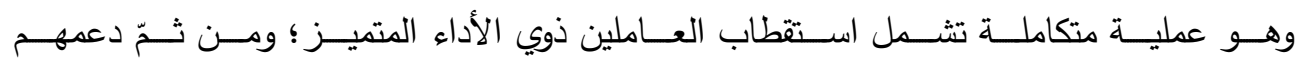

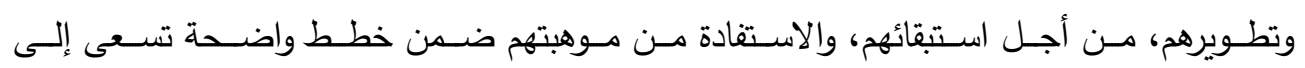
تحقيق أهداف المؤسسة" (صن • (ب). وعرّفهـا شـاندرا (Chandra,2009,

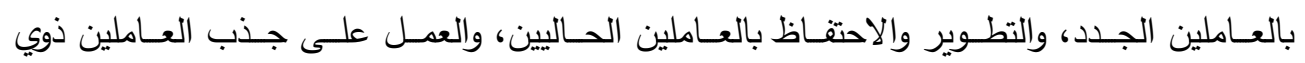
المهارات العالية للعمل في المؤسسة.

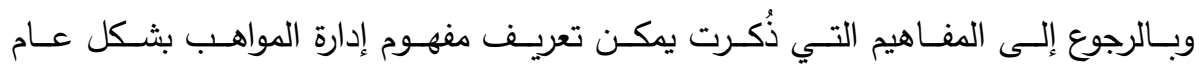

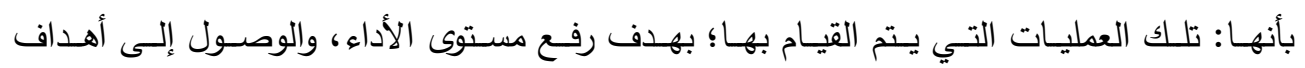

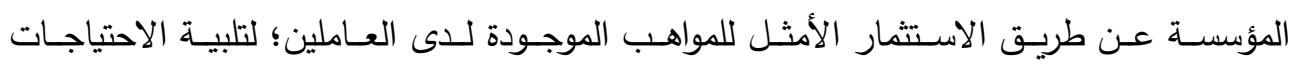

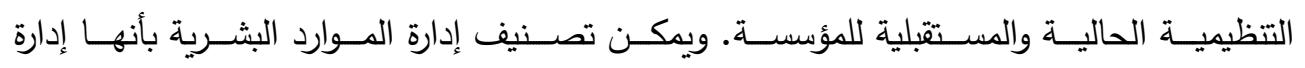

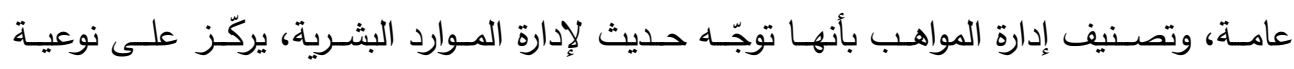
العاملين في المؤسسة من حيث مواهبهم، بثكل أكبر من توفيرهم كمًا. أهداف إدارة المواهب المؤسسية:

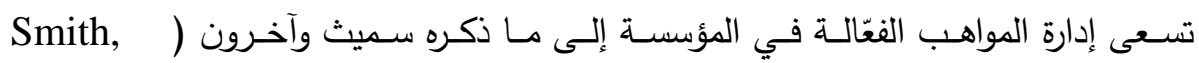
:(et al,2011, p.5 ا. ربط استراتيجية المؤسسة مع كمية ونوعية القيادة المطلوبة والعاملين لتتفيذ ذلك. r. تحديد المواهب التي تتطلع إليها المؤسسة لتحقيق مزايا تتافسية. r. وضع المواهب الجيدة ذات الأداء المتميز في مختلف الوظائف؛ لكسب مهارات متتوعة. ء. تطوير المهارات الجيدة للعاملين؛ للتكيّف مع أي تغيير طارئ. 
ه. تقويم أداء كافة العاملين؛ لنقل مستوى سير العمل إلى أفضل أداء مطلوب.

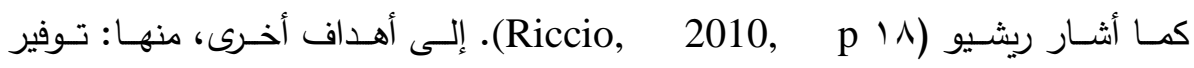

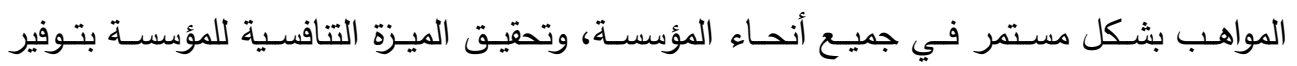

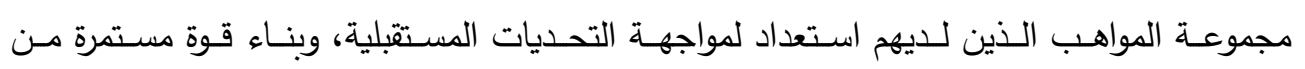
رأس المال البشري، وربط المواهب بالاتجاه المستقبلي للمؤسسة. أهمية إدارة المواهب المؤسسية:

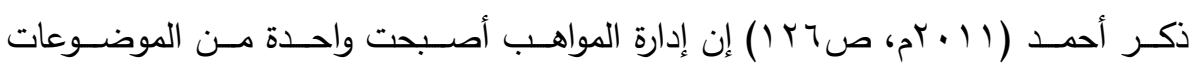

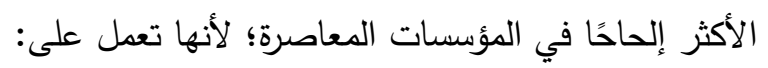
ا ـ بعل عملية التوظيف أكثر كفاءة وفعالية. r. تطوير أداء الأفراد، وتعزيز ثقافة التتمية المستدامة.

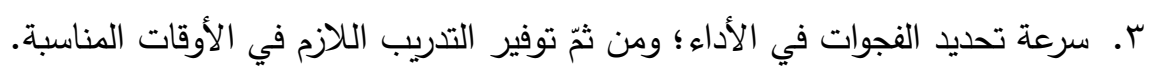
ـ. وضع آليات محددة للقياس والمحاسبة. ه. تحقيق نوع من التكامل بين العاملين في المؤسسة. 7. توفير التدريب المناسب للعاملين والمرتبط بالأعمال.

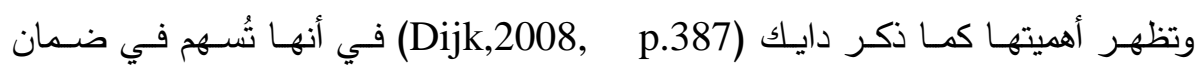

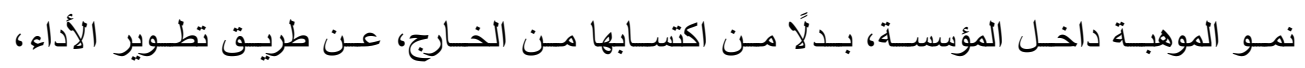

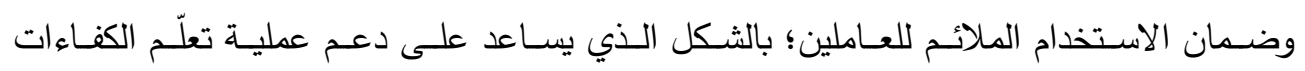
الموجهة ذاتيَّا داخل المؤسسة. خصائص المواهب المؤسسية:

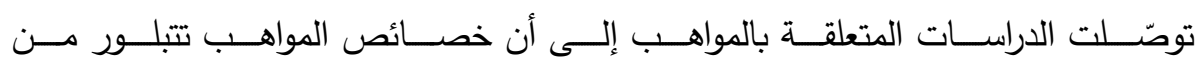

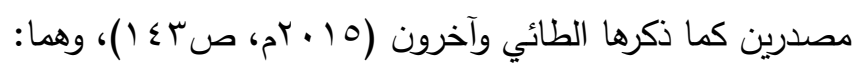

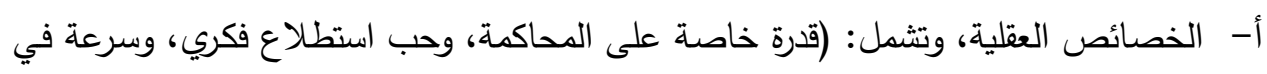
التعلم، والقدرة على التجريد، وعمليات فكرية معقدة، وخيال واضح، والرغبة فئة في التعلم، وقدرة على التركيز ، والتفكير التحليلي، والتفكير الإبداعي، وشعور قوي بالإبداع).

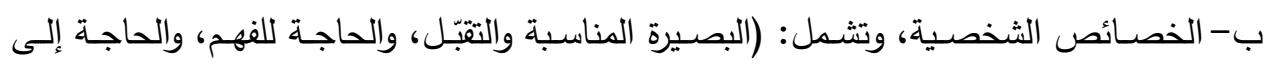
المثيرات العقلية، والحاجة إلى المنطق، وحس ممتاز بالهزل، والمثابرة، ووعي حاد بالذات). 


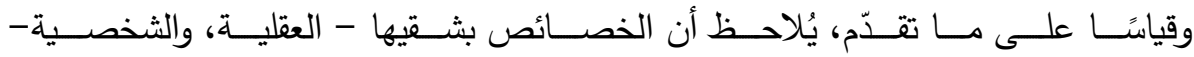

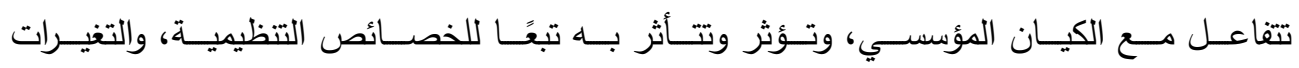

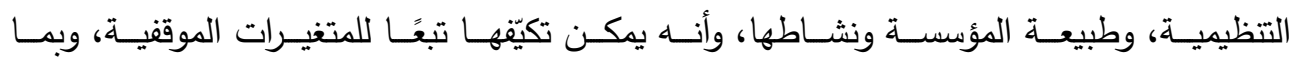
يخدم توجهات المؤسسة. تصنيف المواهب المؤسسية:

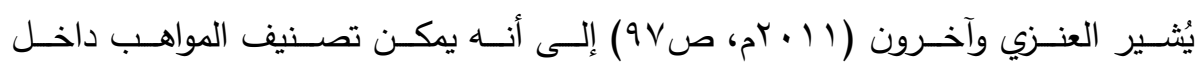
المؤسسة إلى أربعة أصناف، وذلك حسب مستوى المسؤولية لكل صنف منها: ا ـ مواهب قيادية (Leadership Talent). r. rey Talent) مواهب أساسية (Ke). r. بواهب جوهرية Core Talent). ع. مواهب داعمة (Support Talent).

مبررات الاهتمام بالمواهب المؤسسية:

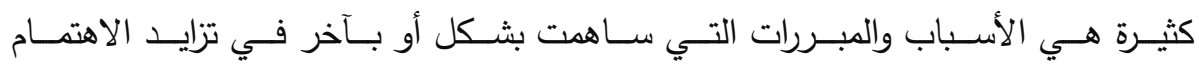

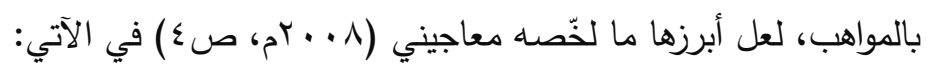

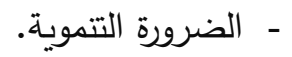

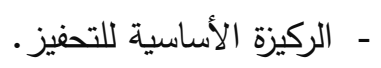

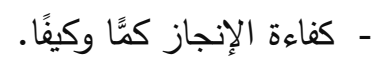

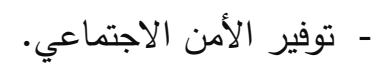

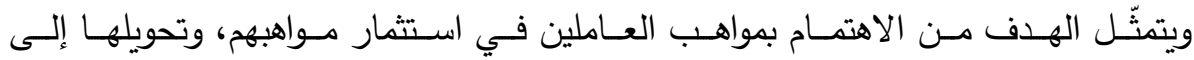

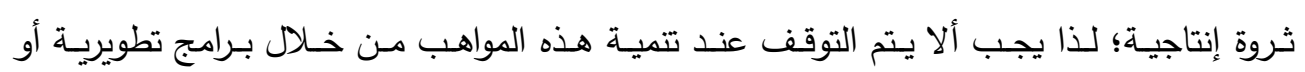

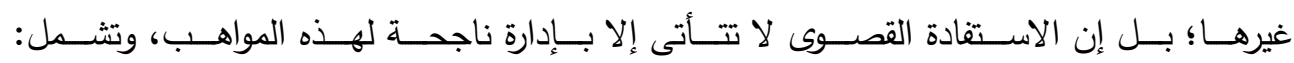

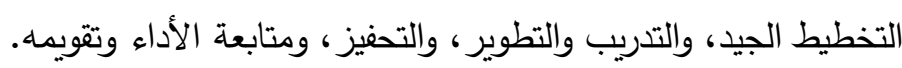
أبعاد إدارة المواهب المؤسسية:

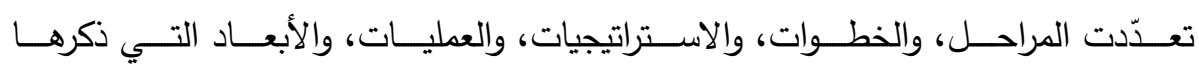

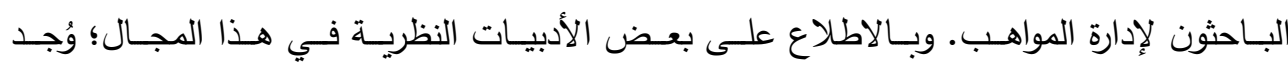

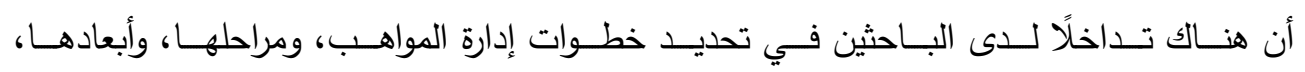

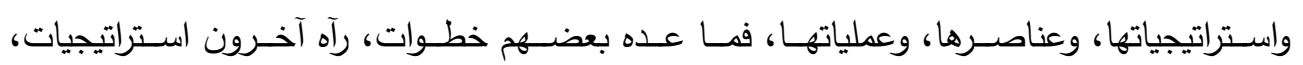


وعـدّه آخـرون عمليـات؛ بينمـا ذكرهـا غيـرهم بوصـفه أبعـادًا لإدارة المواهـب، واكتفـى آخـرون

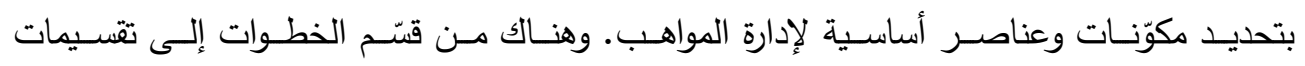

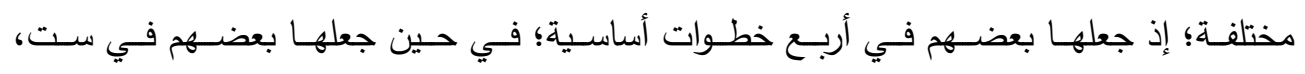
ووصلت عند آخرين إلى ثماني خطوات.

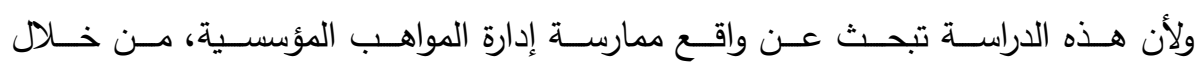

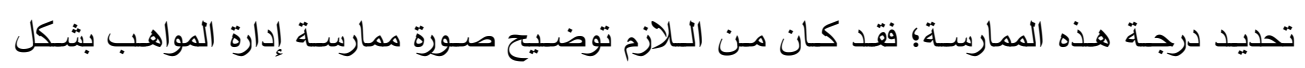

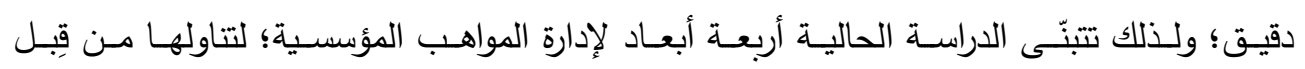

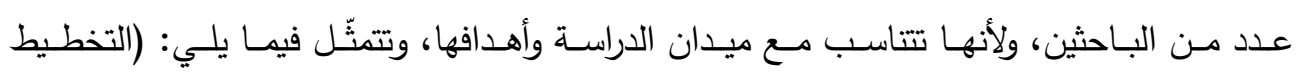

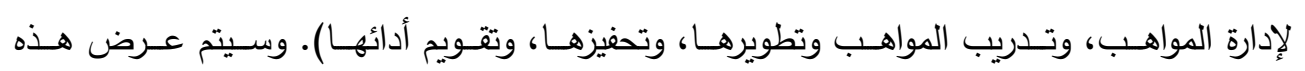
الإبعاد ومناقشتها بإيجاز ، كما يأتي: لإدارن أ- التخطيط لإدارة المواهب:

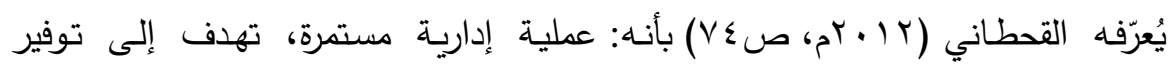

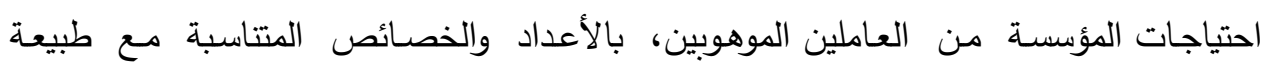
وحجم نشاط المؤسسة، وذلك خلال فترة زمنية مستقبلية، وكذلك دراسة جميع السياسات

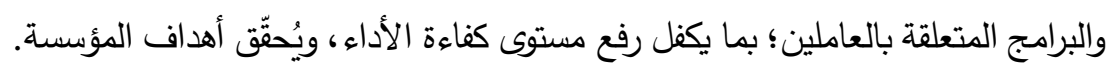

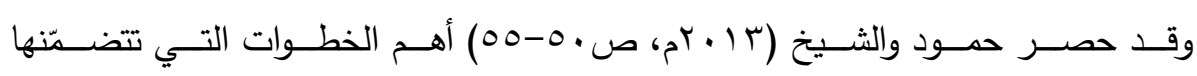
عملية التخطيط لإدارة المواهب في الآتي: ا. توفير قاعدة بيانات شاملة ودقيقة من حيث: عدد العاملين، والمؤهلات العلمية، والمهارات

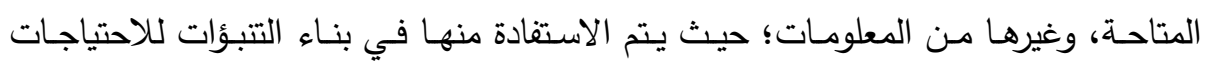

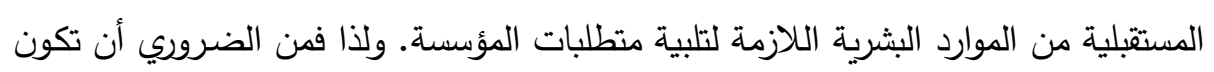

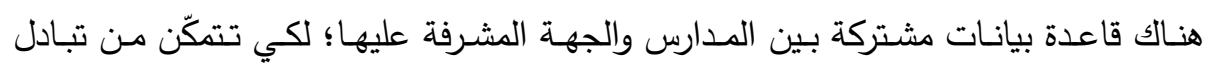
المعلومات، والمشاركة في اتخاذ القرارات بشأن العاملين الموهوبين. r. تحديد الأهداف التنظيمية؛ لأنها تُمثّل نقطة البداية للعملية التخطيطية.

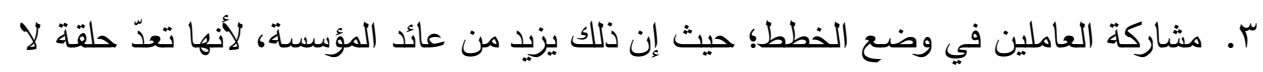

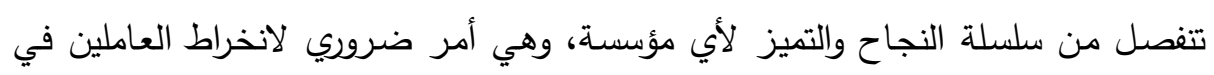

$$
\text { كسؤولياتهم، وحبّهم لعملهم. }
$$

ـ. الاعتماد على تحليل كل الوظائف، وحصر مكوناتها؛ لتحديد متطلباتها. 


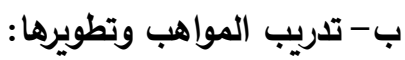

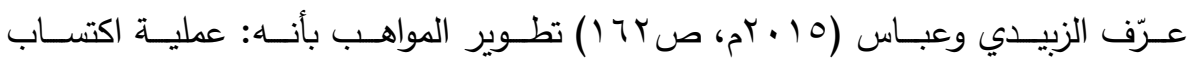

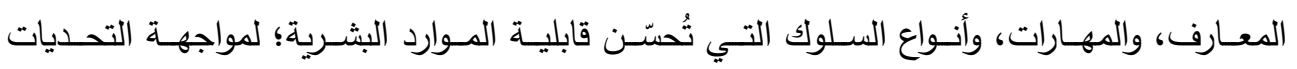

$$
\text { التي تواجه المؤسسات الحالية والمستقبلية. }
$$

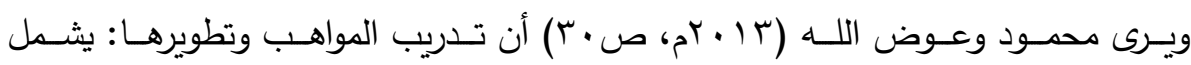

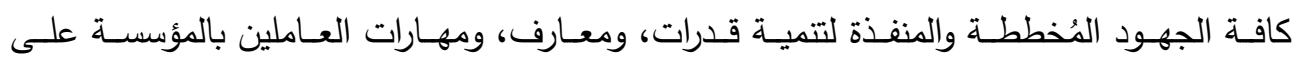

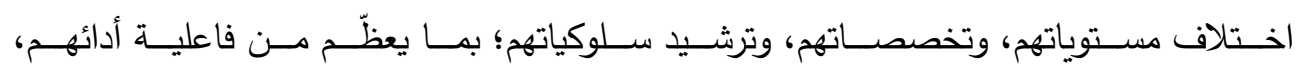

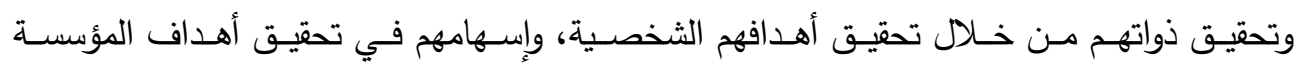

الحالية والمستقبلية.

خطوات تصميم أنشطة تدريب المواهب الفعّالة وتطويرها:

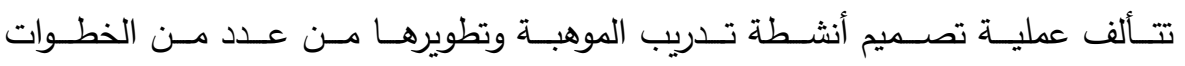

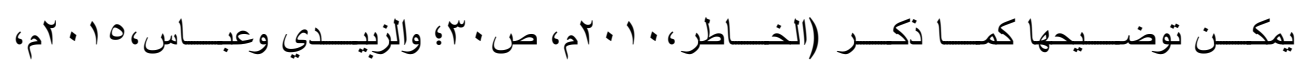

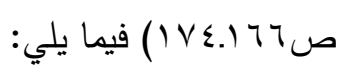

- الخطوة الأولى: تحديد الاحتياجات التدريبية والتطويرية للمواهب، ويستلزم ذلك القيام بعدد من

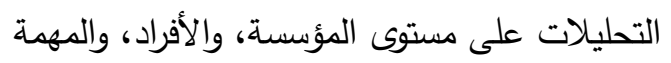

- الخطوة الثانية: ضمان جاهزية الموارد البشرية الموهوبة واستعدادها للتدربب والتطوير .

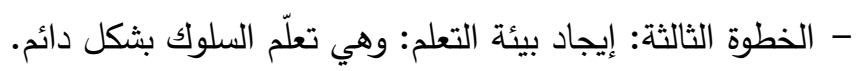

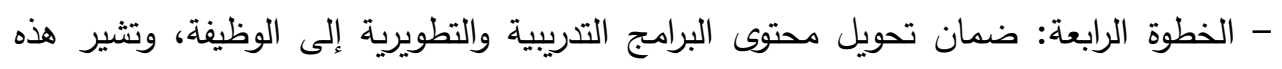
الخطوة إلى استخدام المعرفة، والمهارات، والسلوكيات التي تم تعلمها في التدريب على التهات الوظيفة.

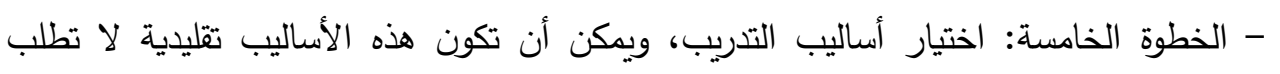
التكنولوجيا في تطبيقها، ويمكن أن تكون حديثة تعتمد على التكنولوجيا في تطبيقها، كما يمكن لقيادات المؤسسات أن تعتمد على المصادر الداخلية في تتفيذ البرامج التدريبية، ويمكن أن أن

$$
\text { تعتمد على المصادر الخارجية. }
$$

ج- تحفيز المواهب:

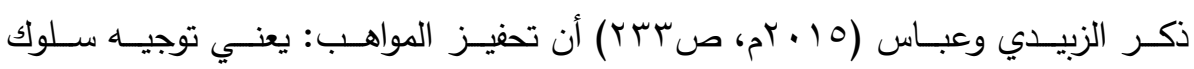

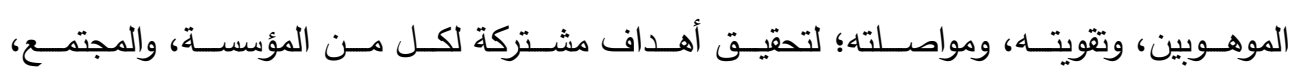




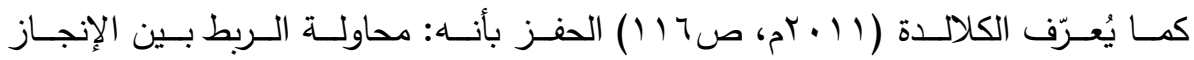

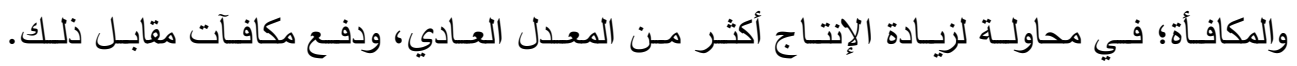

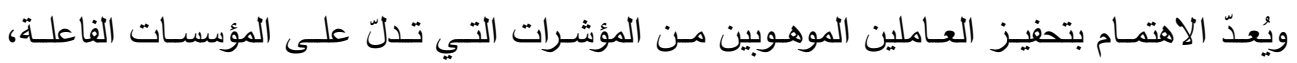

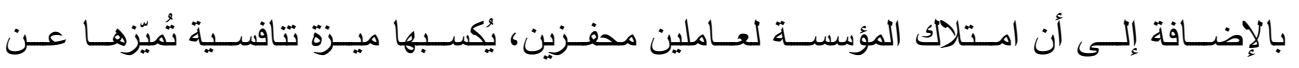

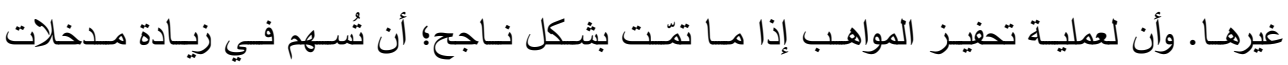

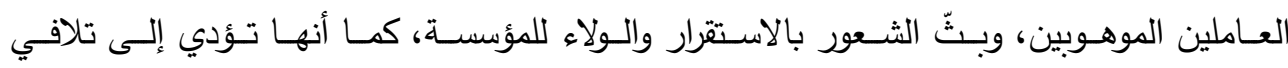

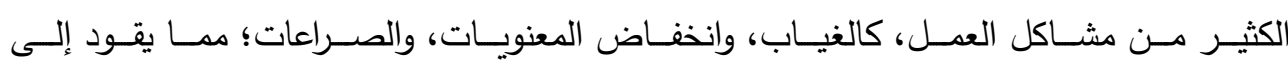
إيجاد استقرار أعلى في الموارد البشرية الموهوبة التي تمتلكها المؤسسة. أنواع الحوافز:

يمكـن تقسـيم الحـوافز على أسـاس أسـلوب دفعهـا - والتـي تعتــــها قيـادة المؤسسـات

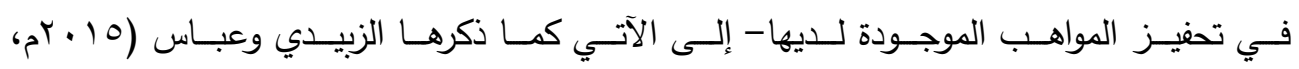

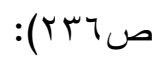
ا. الحوافز الفردية: تقوم خطط التحفيز الفردي على مكافأة الأداء الفردي.

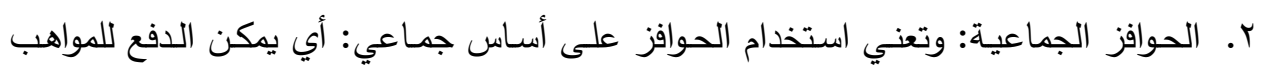
استنادًا إلى أدائهم المختلط، وتقضّل الحوافز الجماعية عندما تكون واجبات المواهب مترابطة، ومعتمدة، وتتطلّب التعاون.

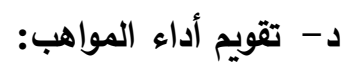

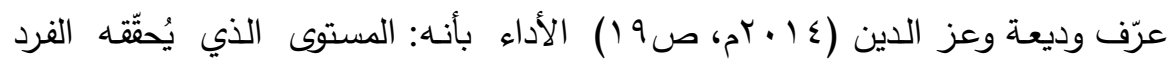
العامل عند قيامه بعمله من حيث كمية وجودة العمل المُعَّم من طرفه. ويُعرّف أيضًا بأنها:

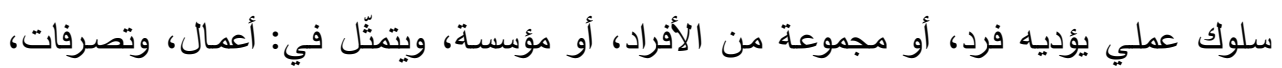
وحركات مقصودة من أجل عمل؛ لتحقيق هدف أو أهداف محددة.

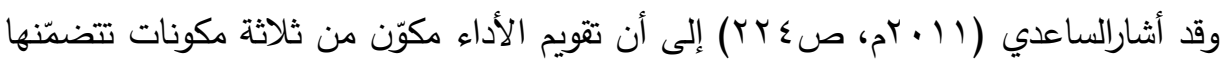

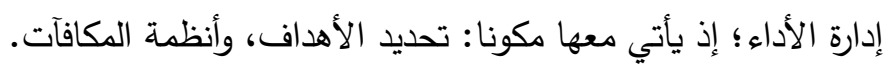

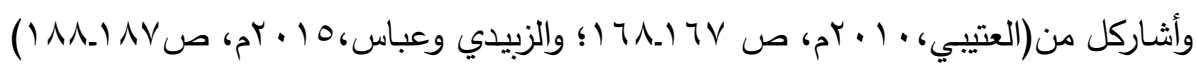
إلى أهمية تقويم أداء المواهب، وذلك على النحو الآتي: ا . يساعد على توجيه القيادة إلى مراكز المسؤولية التي تكون بحاجة إلى إثراف. 
r. يقوم على ترشيد الطاقـة البشـرية بالمؤسسـة في المستقبل؛ إذ يتم إبراز العناصـر الناجحـة وتتميتها، وإبراز العناصر غير المنتجة التي يتطلّب الاستغناء عنها. r. مساعدة القيادات على اتخاذ القرارات التي تحقّق الأهداف.

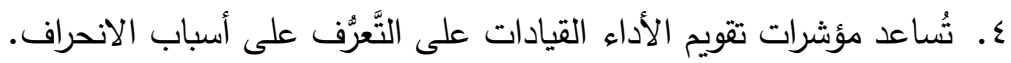

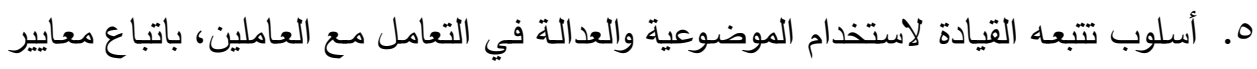
واقعية وقياسية محددة. T. يُشْكل فرصة للموارد البشرية لتدارك أخطائهم، والعمل على تجنّبها، وتتمية مهاراتهم، وتحقيق

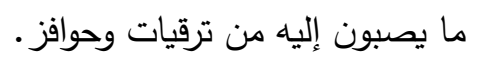

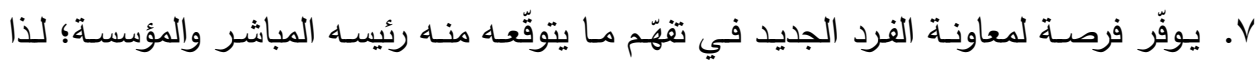
فالتقويم يقيس فاعلية المؤسسة في استخدام مواهبها البشرية. معوقات إدارة المواهب المؤسسية:

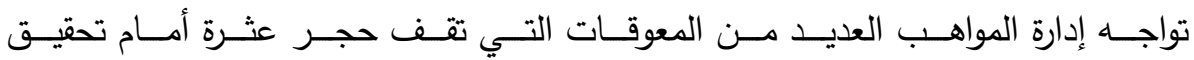
أهدافها، ومن أبرز هذه المعوقات كما ذكر ويليام (William,2006, p.7): - عدم وجود الممارسات القيادية التي تسعى للتغيير •

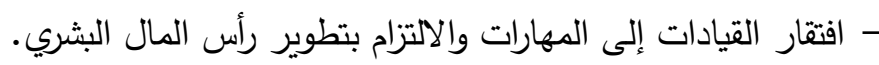
- وجود مقاومة من بعضهم لعمليات التقييم التي تركّز على المواهب. - عدم وجود التوافق بين استراتيجية المؤسسة واستراتيجية إدارة المواهب. - عدم وجود خطة لمعالجة حالات نقص الأداء المزمنة.

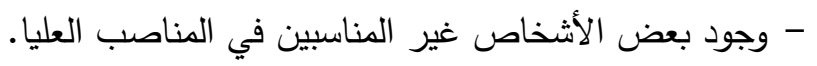
عوامل نجاح ممارسة إدارة المواهب المؤسسية:

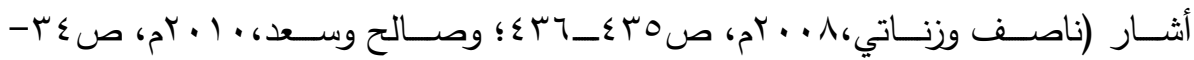

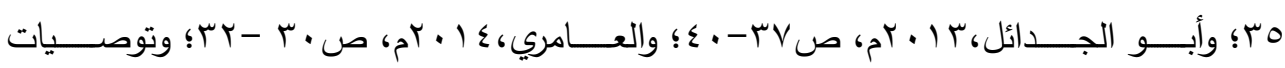

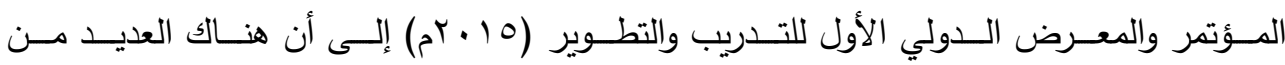
العوامل المتعلقة بنجاح ممارسة إدارة المواهب، ومنها:

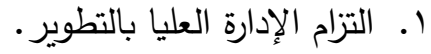
r. التعزيز التظيمي لجهود التطوير. 
r. اتخاذ القرار بشأن الموهبة بحيث يراعى أن يكون التوظيف بناء على مدى توافق المرشحة مع

$$
\begin{aligned}
& \text { المؤسسة. } \\
& \text { ع. ضبط معايير الأداء ومراقبتها. } \\
& \text { ه. الاستفادة من فكر المواهب بالمدارس. } \\
& \text { 7. اختيار الخَلَف بناء على القدرات القيادية. }
\end{aligned}
$$

V. المراجعة المستمرة للميزانية المخصصة؛ لتتمية المواهب، وتطويرها. ^. المحافظة على المواهب، والعمل على استبقائهم في المؤسسة.

$$
\text { دور القائد في إدارة المواهب المؤسسية: }
$$

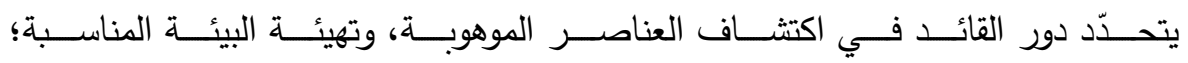

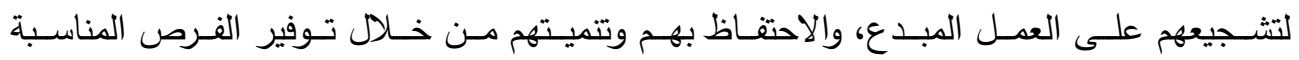

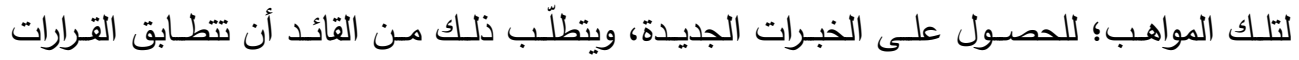

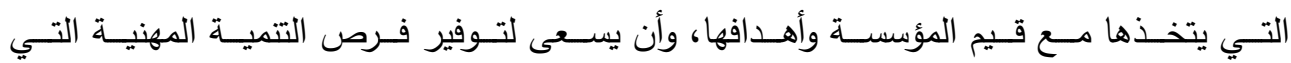

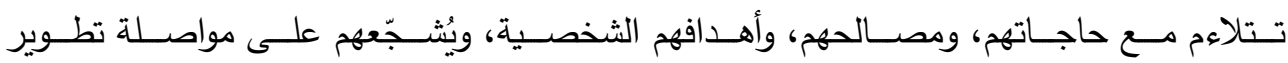

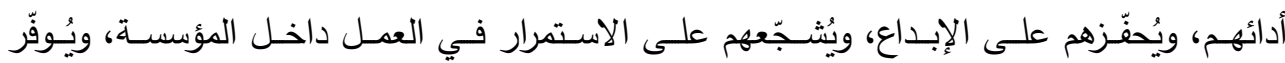

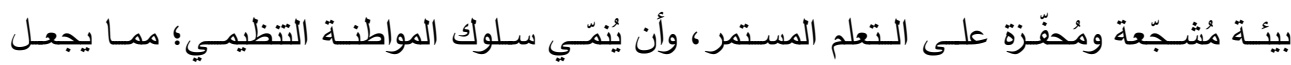

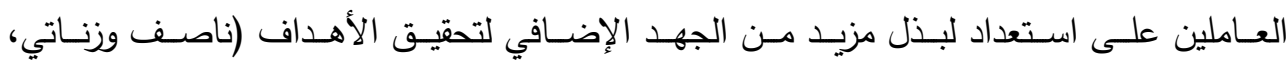

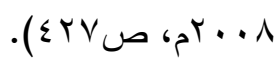
المبحث الثاني : القيادة المدرسية

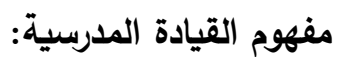

القيـادة لغـة: "يُقتـال: قـاد الدابـة قـودًا، وقيـادًا، وقيـادة: إذا مشـى أمامهـا آخـذاً بمقودهـا.

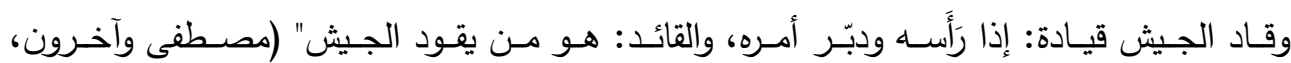
(V)

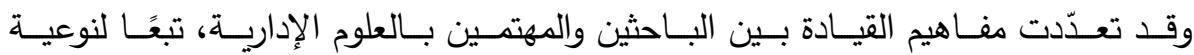

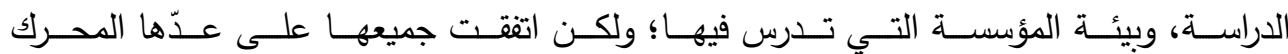
الأساسي للمؤسسة والعاملين فيها؛ من أجل تحقيق أهداف المؤسسة.

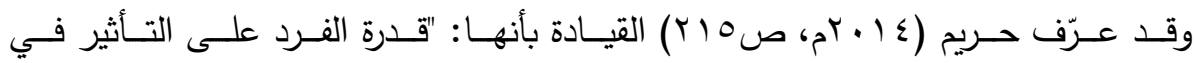

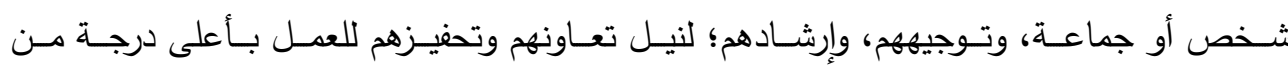




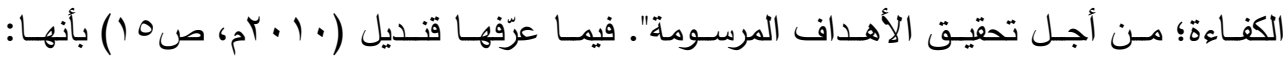

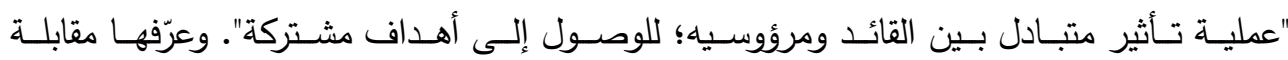

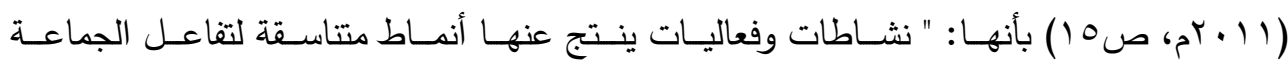
نحو حلّ المشكلات المتعددة".

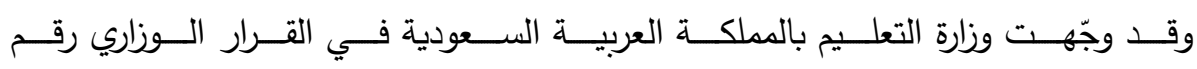

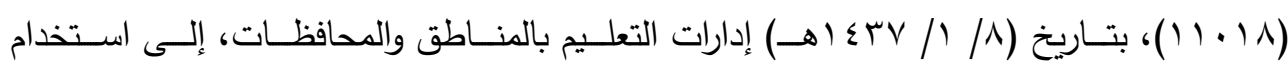

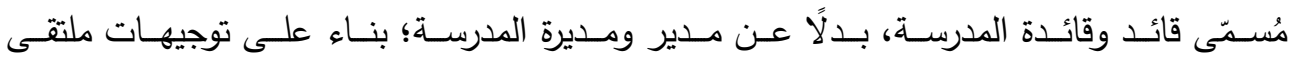

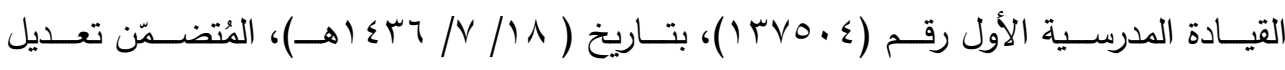

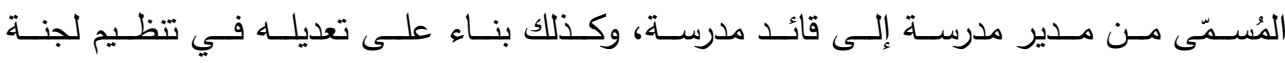

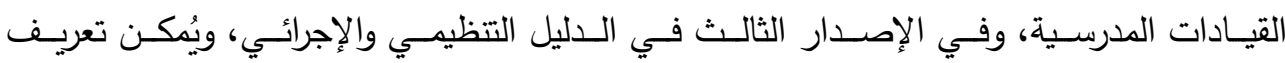

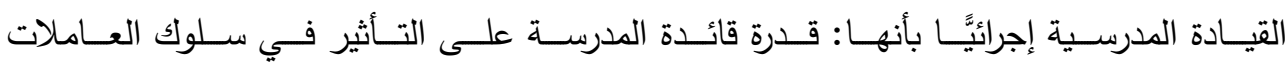

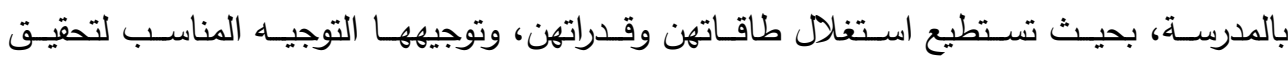
أهداف المدرسة.

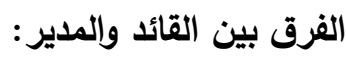

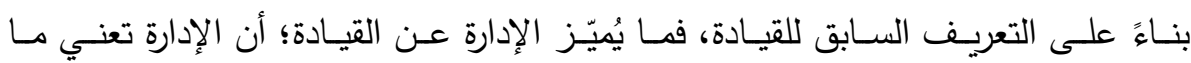

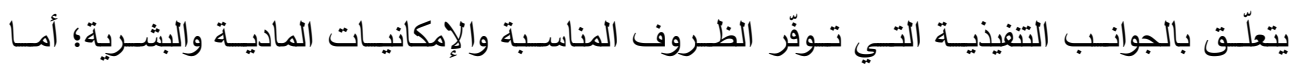

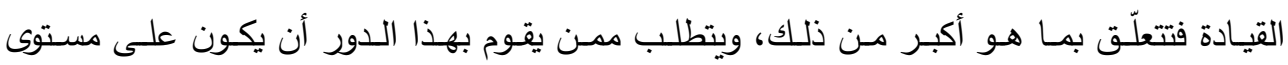

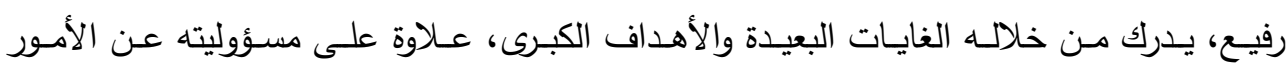

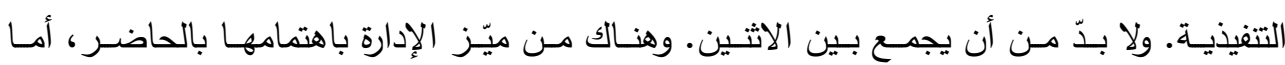

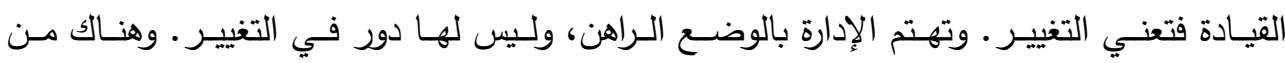

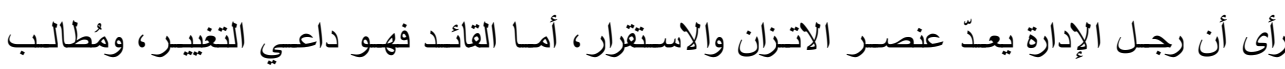

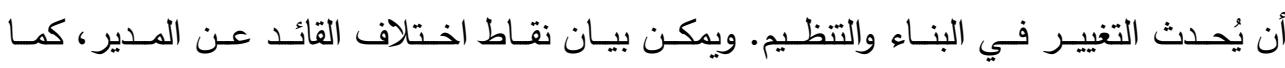

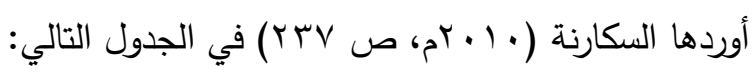

جدول رقم ( ) : الفرق بين الإدارة والقيادة

\begin{tabular}{|c|c|}
\hline 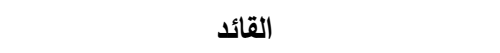 & 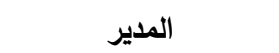 \\
\hline يركّز على المستقبل وتوجيهاته طويلة المدى. & يركّز على الحاضر . \\
\hline يُعبِّر عن الثثافة والقير السائدة. & يُطبِّق السياسات واللوائح. \\
\hline
\end{tabular}




\begin{tabular}{|c|c|}
\hline يُقيتم علاقات ودية مع الأفراد. & يظلّ محايدًا للوصول إلى قرار موضوعي. \\
\hline يستخدم قوة التأثير الثخصي، ويعمل من خلال حب الجماعة. & يستغلّ مكانته في المؤسسة لتحقيق أهدافها. \\
\hline
\end{tabular}

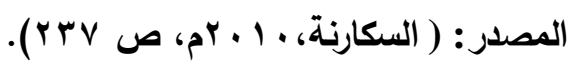

أهمية القيادة المدرسية: - n

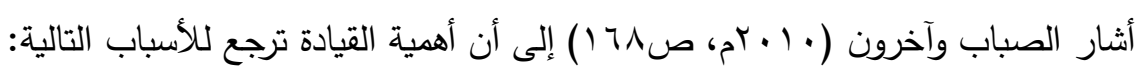
- - بدون القيادة لا يستطيع القائد تحويل الأهداف المطلوبة منها إلى نتائج.

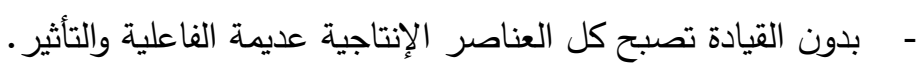

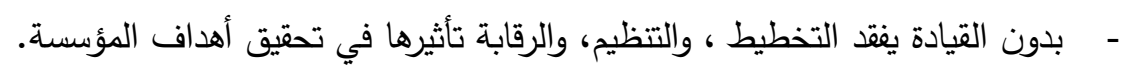

- - بدون القيادة يصعب على المؤسسة التعامل مع متغيرات البيئة الخارجية.

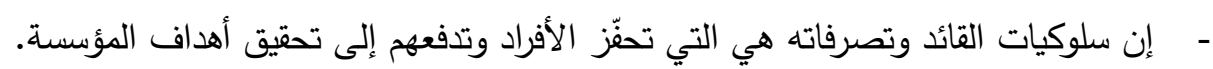

أنماط القيادة المدرسية:

هنـاك علاقـة وثيقـة بـين الــمط القيـادي وفعاليـة المدرســة ونجاحهـا فـي أداء رسـالتها؛

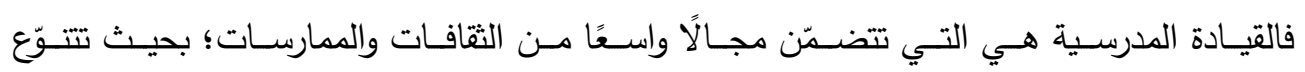

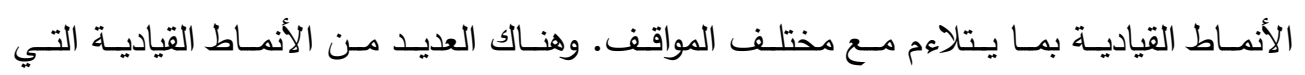

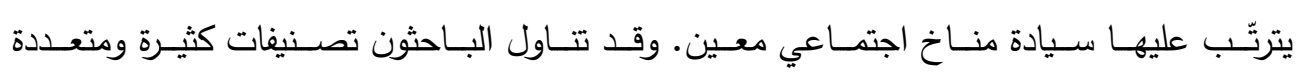

وقسموها لأنماط مختلفة، منها:

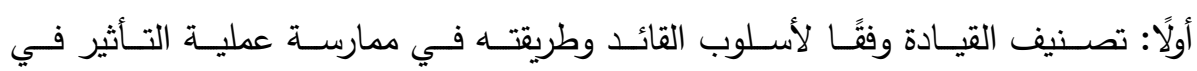

العاملين معه، وعلى أساس هذا المعيار صنّّت أساليب القيادة إلى:

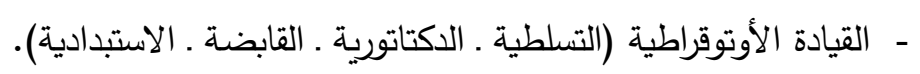

- القيادة الديمقراطية (الثراكة ـ التشاركية ـ الثورية).

- القيادة الترسلية: (التسيبية ـ المنطلقة ـ الفوضوية ـ الحرة).

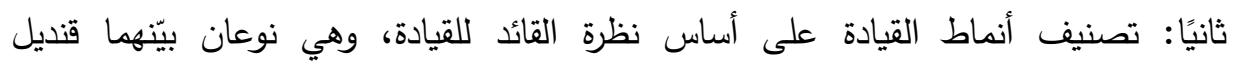

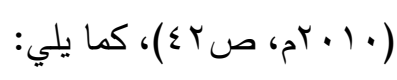

$$
\begin{aligned}
& \text { - قيادة رسمية. } \\
& \text { - قيادة غير رسمية. }
\end{aligned}
$$

ثالثًا: تصنيف أنماط القيادة على أساس الاتجاهات المعاصرة للقيادة: 
يتبنّى الفكر الإداري المعاصر مفهومًا جديدًا وأنماطًا حديثة للقيادة الإدارية تتوافق مع مجمل

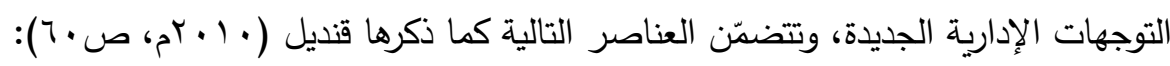
- - القيادة تتسيق لجهود الموارد البشرية. - - القيادة توجيه وإرشاد نحو الأهداف.

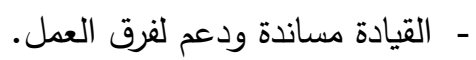

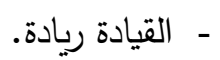

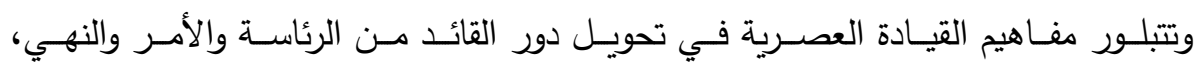

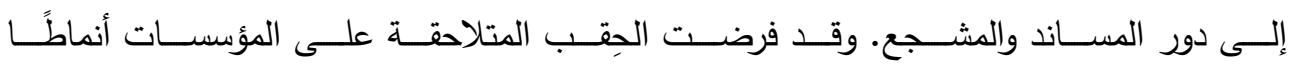

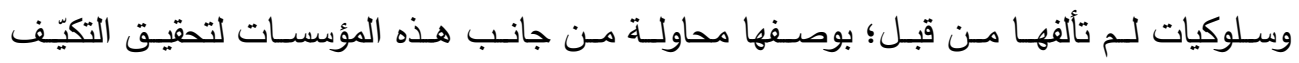
وبلوغ مستويات الأداء المنشودة، وكان منها:

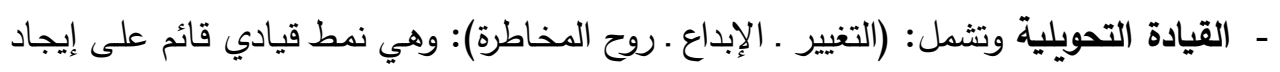

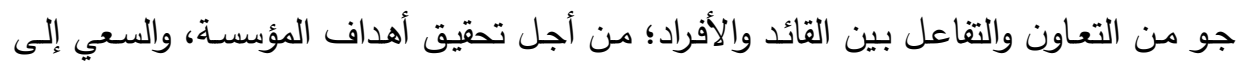

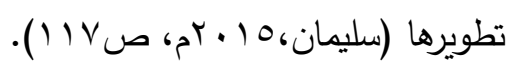

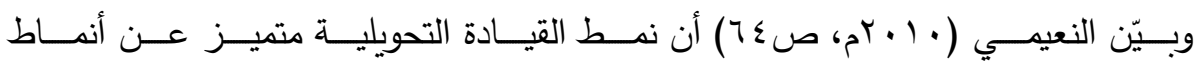

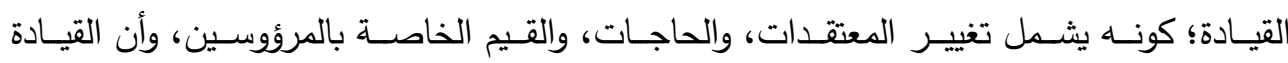
التحويلية تحثّ المرؤوسين على تخطي التوقّعات الأصلية.

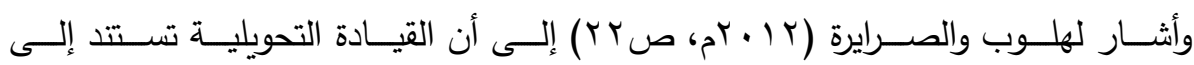

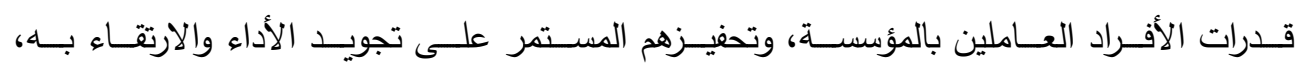

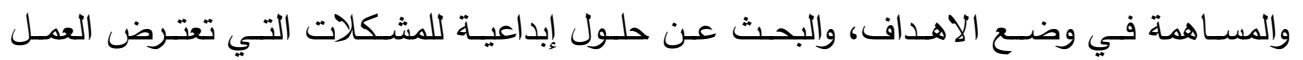

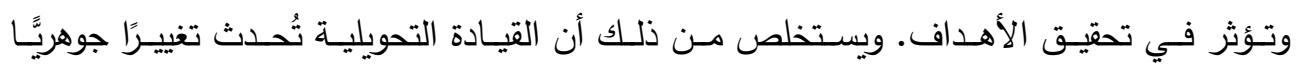
في التابعين؛ وبالتالي في المؤسسة.

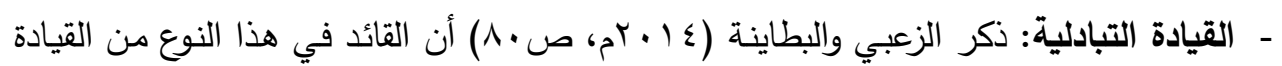

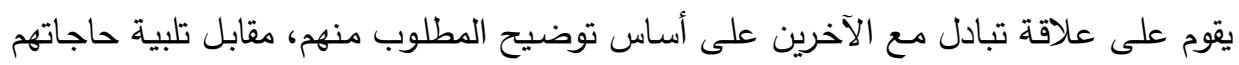

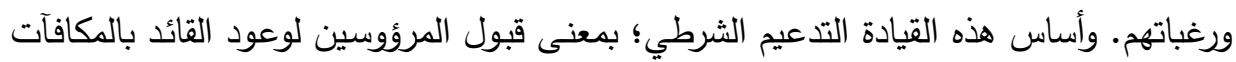

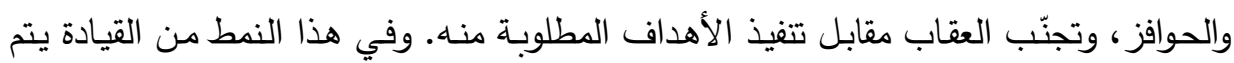
التركيز على الاهتمام بالإنتاج، ومراعاة حاجات الأفراد ورغباتهم.

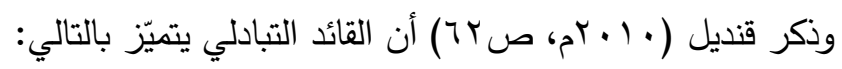


- - تحديد الأهداف وإجراءات تتفيذها للعاملين. - تصميم هيكل العمل، ويُكلف العاملين بالمهام. - تصايد - ـ التعاون مع المرؤوسين من خلال مبادلة جهودهم بالحوافز والمكافآت، وتجنّب العقاب. - يبحث عن الانحرافات، ويتخذ الإجراءات لتصحيحها.

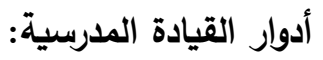

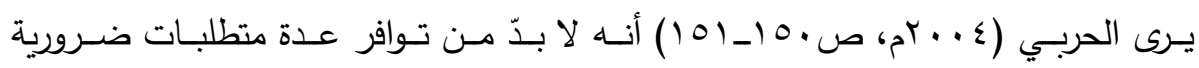

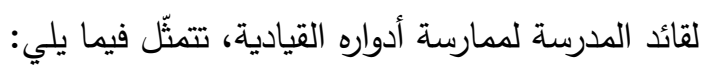
ا. قدر كبير من التعليم والخبرة في مجال العمل الإداري التربوي.

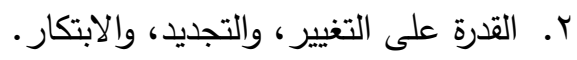

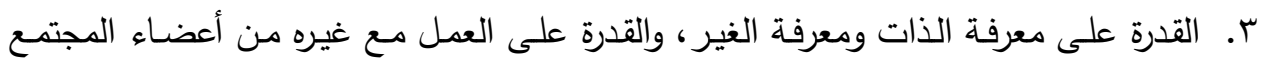
المدرسي، وتحفيز طاقاتهم على التعاون المثمر الذي يُحقّق أهداف التعليم.

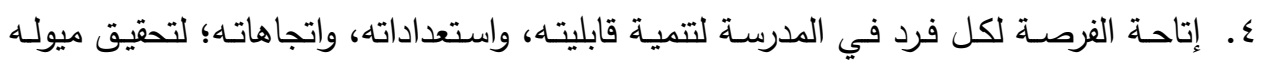
ضمن إطار من الحرية والميؤولية، والقدرة على اتخاذ القرارات الصحيحة البنّاءة. ه. تهيئة بيئة العمل؛ لتحقيق الثبات والاستقرار في العمل دون اضطراب أو انقطاع.

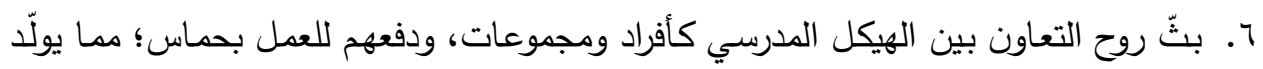

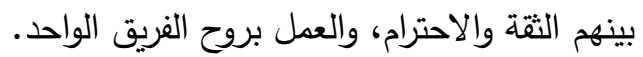
V. الإلمام بطرق تتمية المعلمين مهنيًّا، وتحسين المنهج المدرسي، وإثراؤه، وتتفيذه.

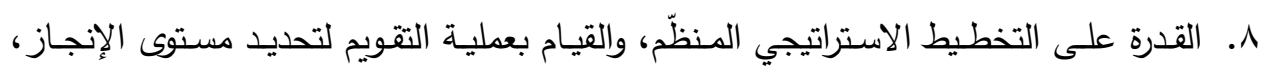
ومدى تحقيق أهداف الخطة المدرسية، والتجهيز للخطة القادمة. 9. استخدام الوسائل المتتوعة من التقويم، مع ضرورة اتصافها بالصدق، والثبات والموضوعية،

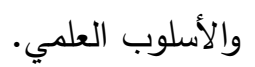

\section{المهارات الواجب توفّرها لاى قائد المدرسة:}

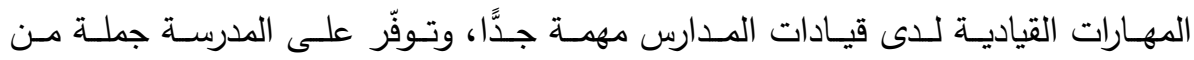

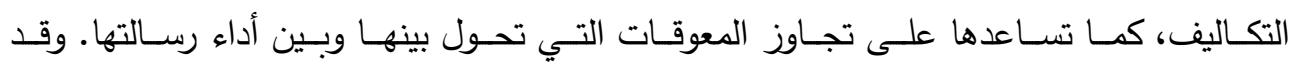

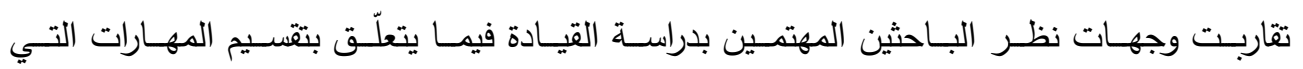

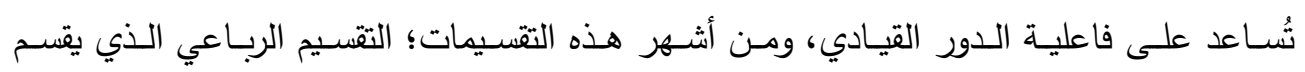
المهـارات القياديـة إلـى: مهـارات ذاتيـة، ومهـارات فنيـة، ومهـارات إنسـانية، ومهــارات إدراكيـة. 


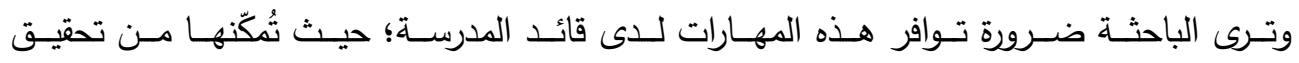

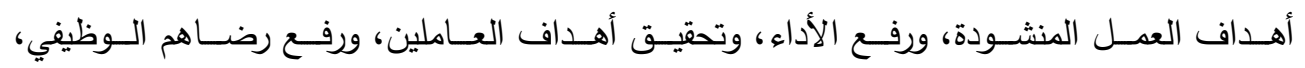

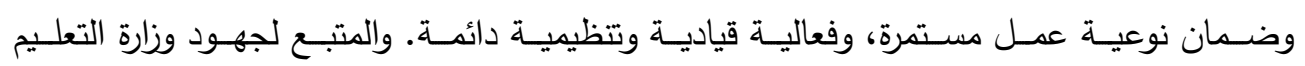

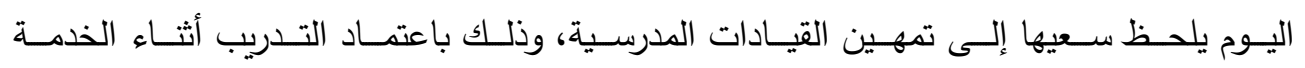
أسلوبًا لتأهليهم، وتجويد أدائهج، وإكسابهم المهارات القيادية.

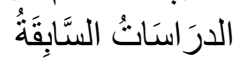

فيمـا يلـي بعـض الدراسـات السـابقة المُتعلقــة بموضـوع الدراســة الحاليـة "إدارة المواهـبـ

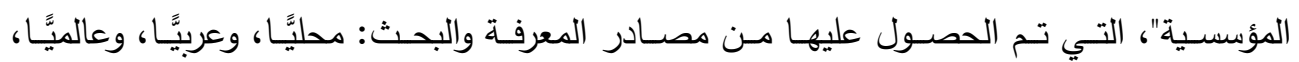
وقد تم إدراجها وفقًا للترتيب الزمني من الأقدم إلى الأحدث على النحو الند التالي:

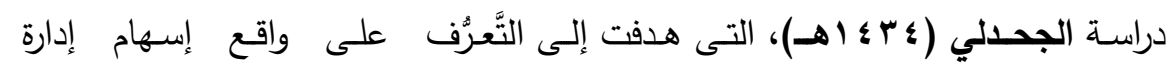

المواهب في تتمية الموارد البشرية الأكاديمية، والتّعرّف على المتطلبات اللازمة لتطبيق إدارة

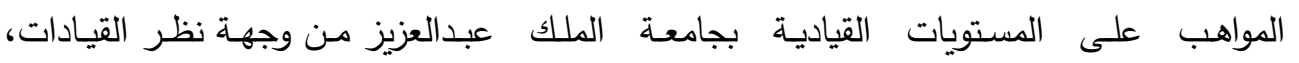

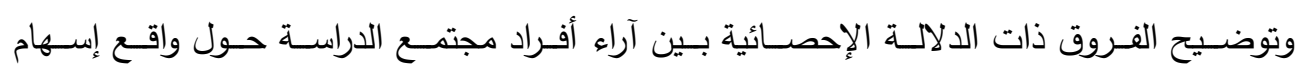

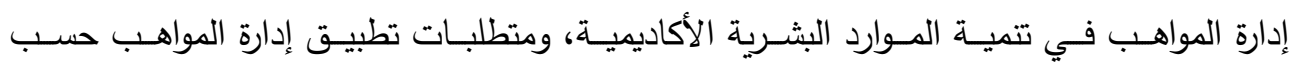

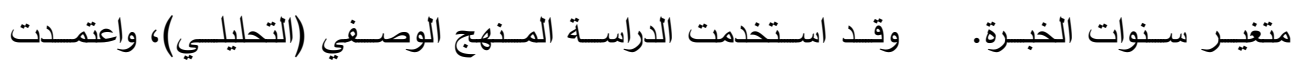

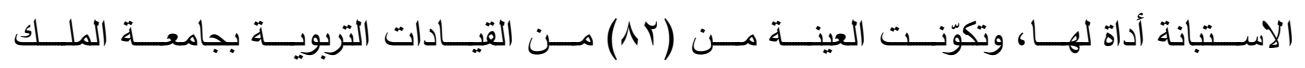

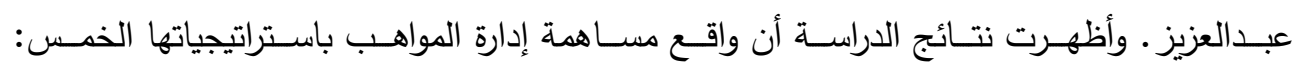

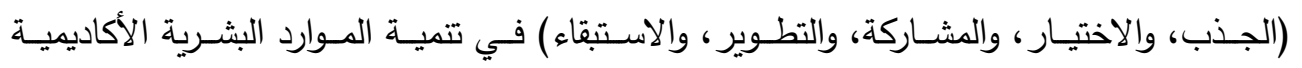

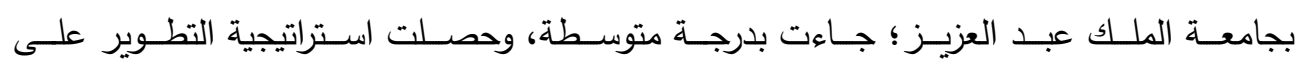

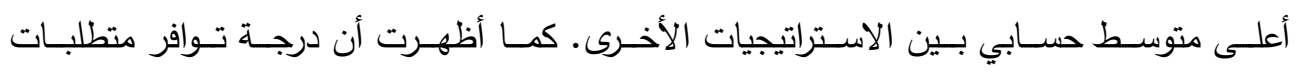

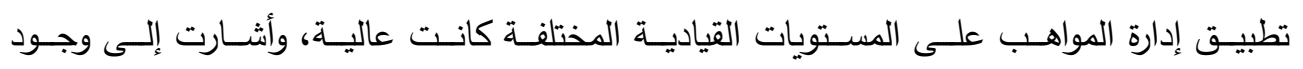

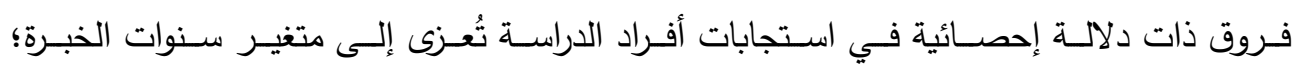

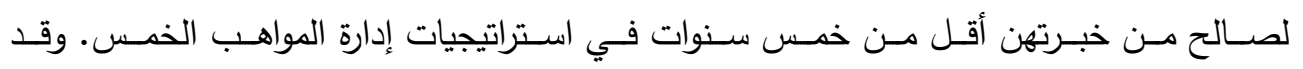

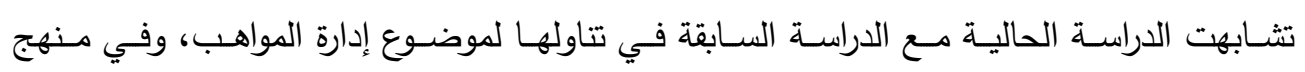

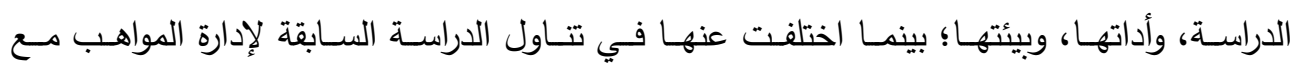
متغير تتمية الموارد البشرية، وفي هدف الدراسة ومجتمعها. بينها 


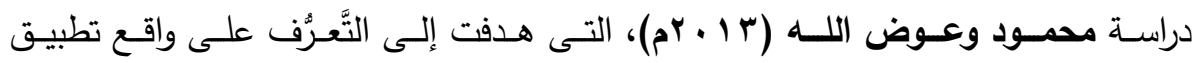

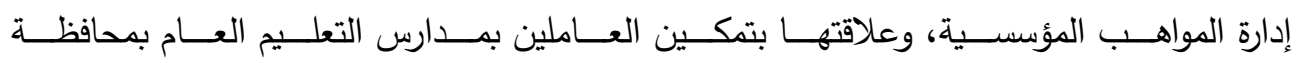

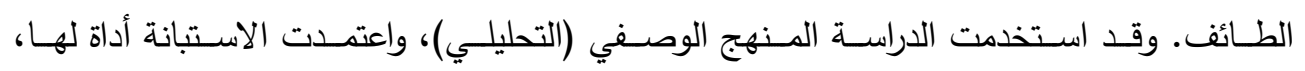

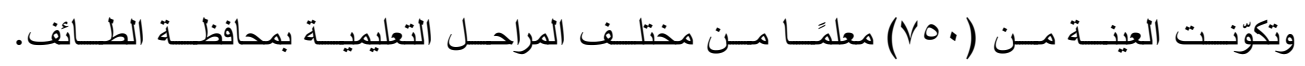

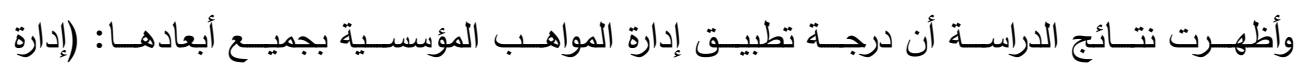

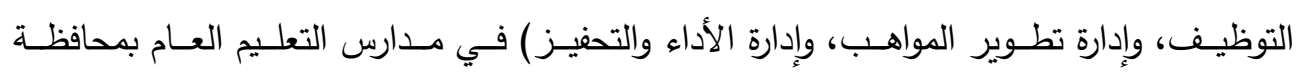

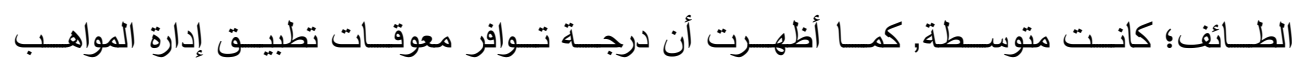

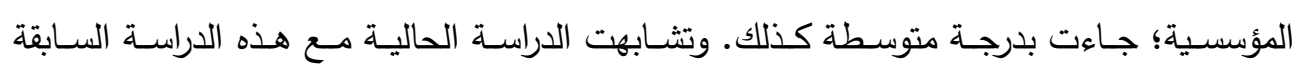

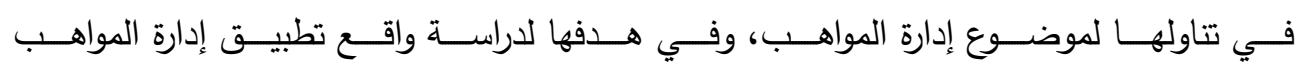

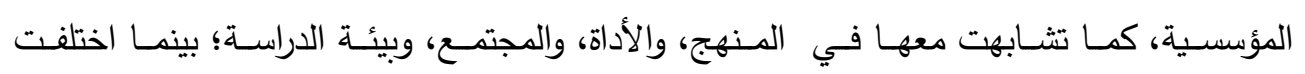
عنها في ربط الدراسة السابقة لإدارة المواهب مع متغير تمكين العاملين.

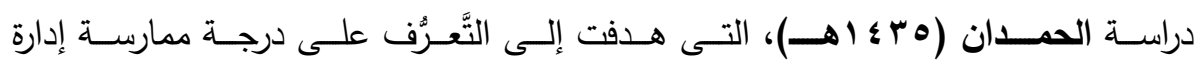

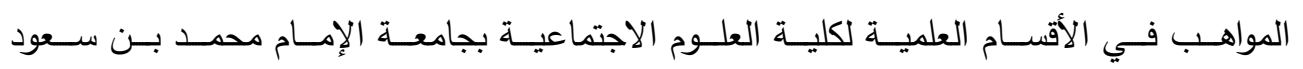

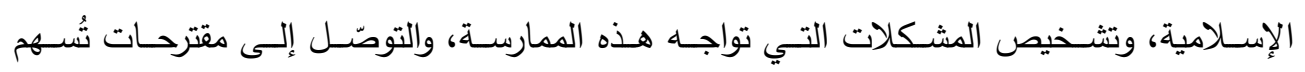

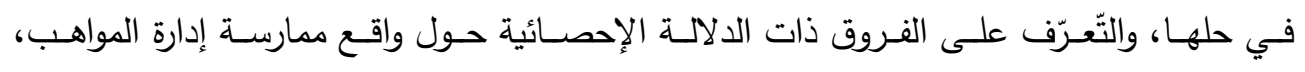

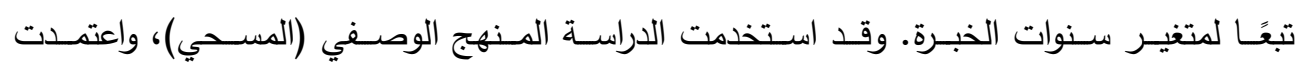

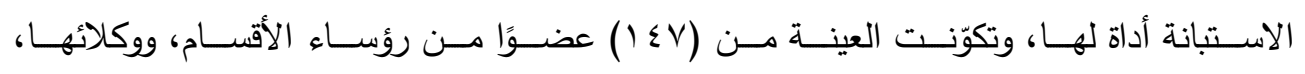

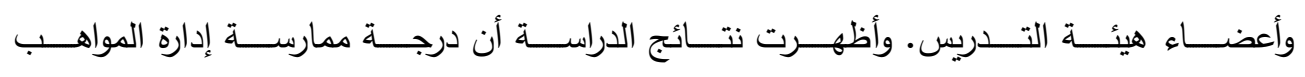

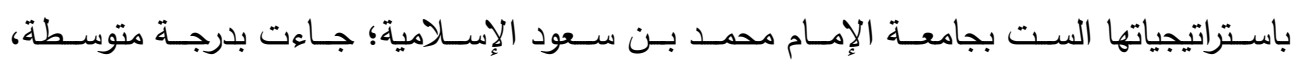
وأن الأقسام العلمية لكلية العلوم الاجتماعية بجامعة الإمام محمد بن سعود الإسـلامية تواجها

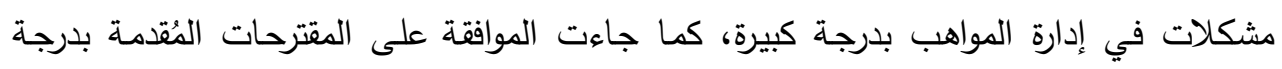

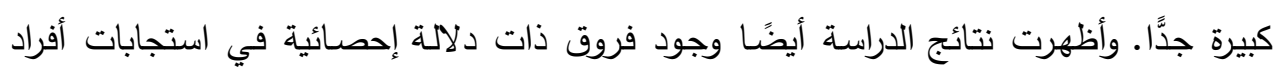

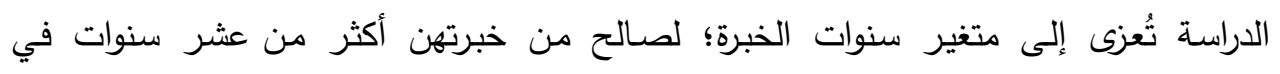

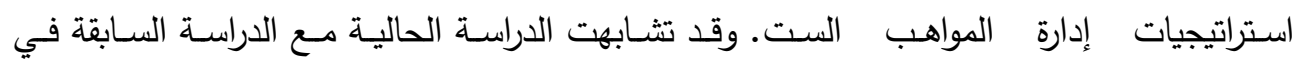

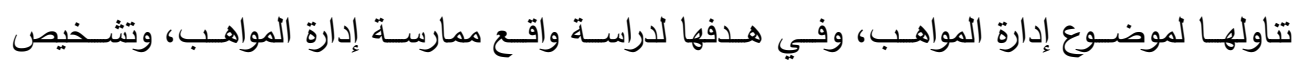

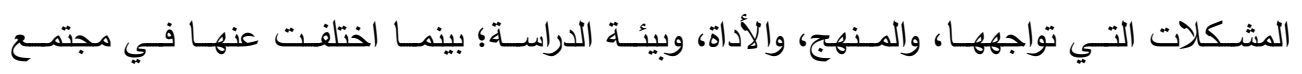
الدراسة. 


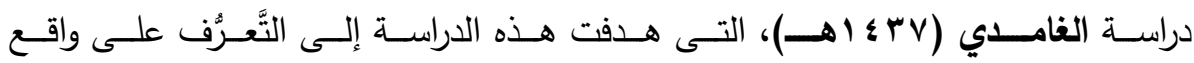

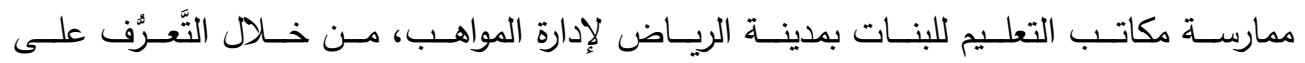

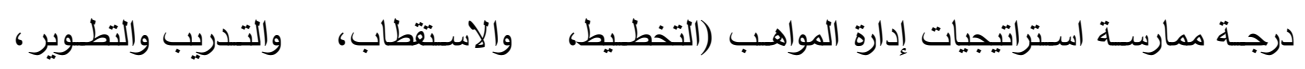

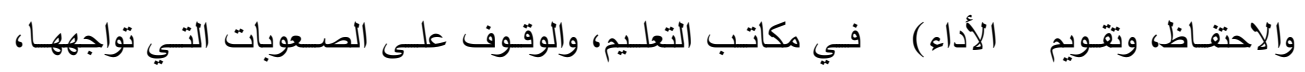

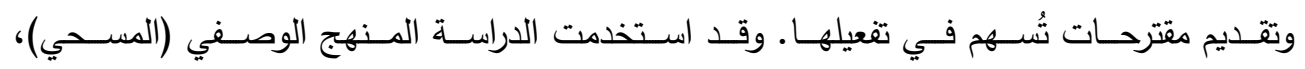

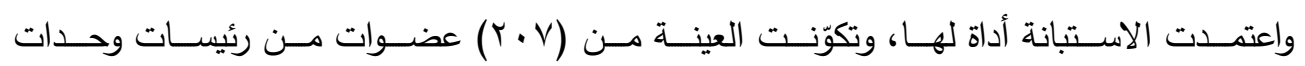

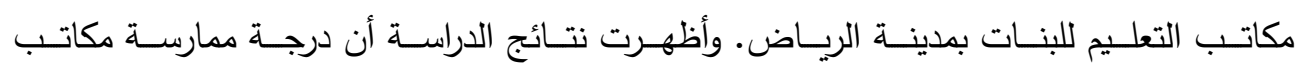

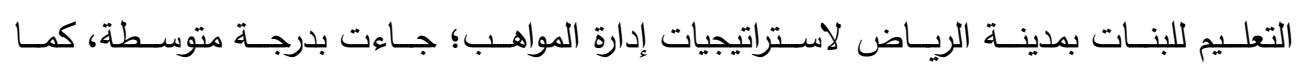

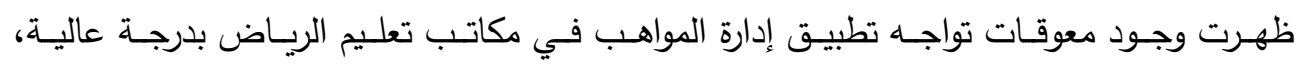

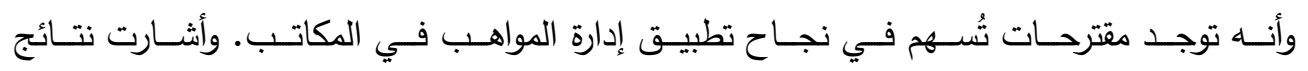

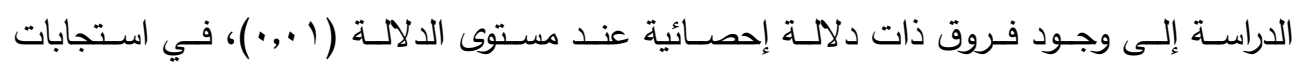

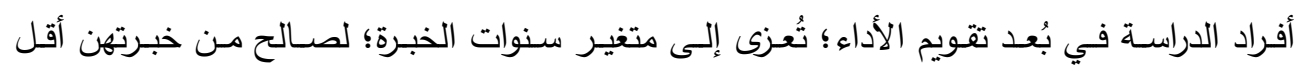

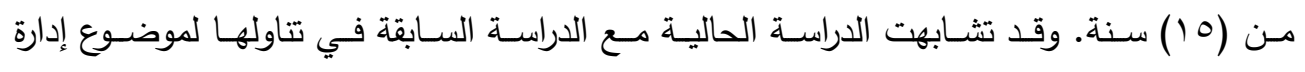

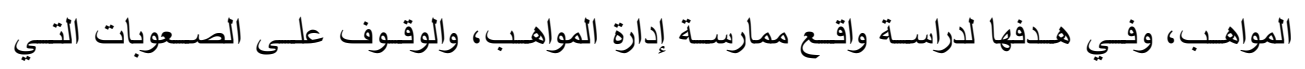

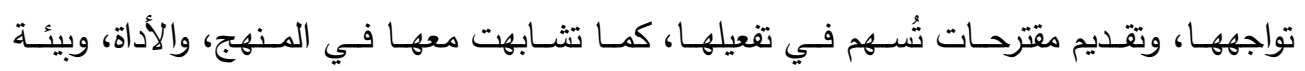
الدراسة؛ بينما اختلفت عنها في مجتمع الدراسة. دراسـة مقتــدي وتــاجي (Moghtadaie and Taji,2016)، التـى هـدفت هــهـ

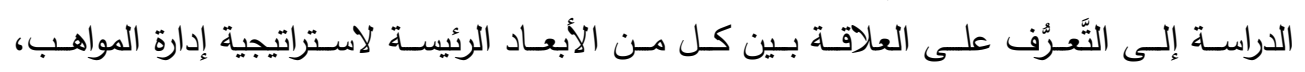

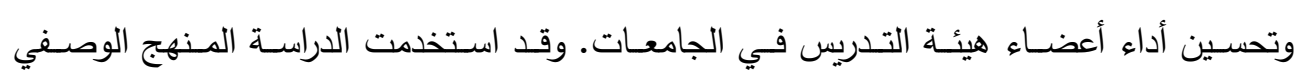

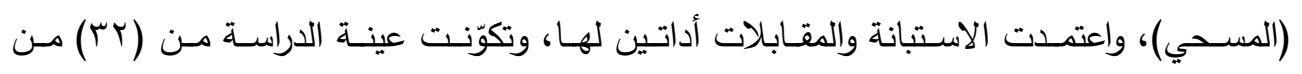

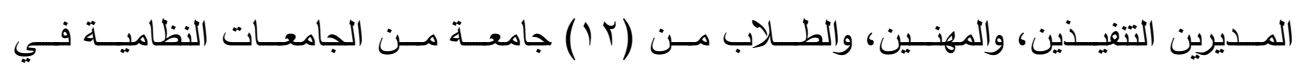

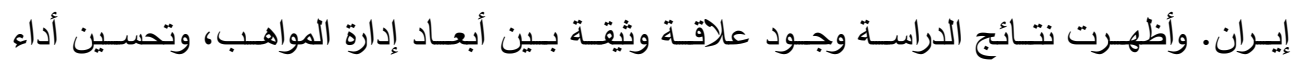

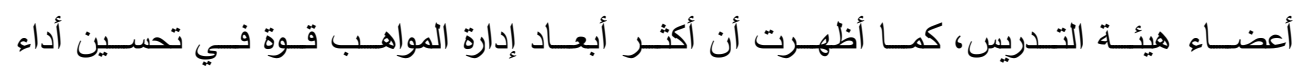

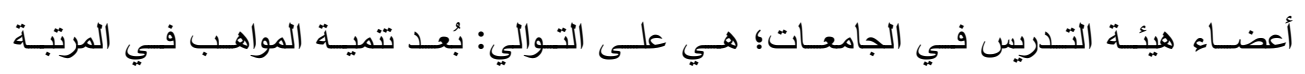

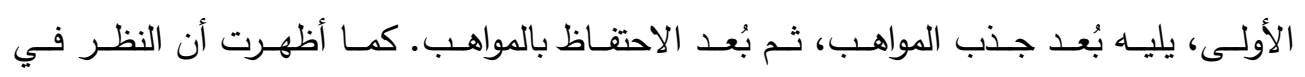

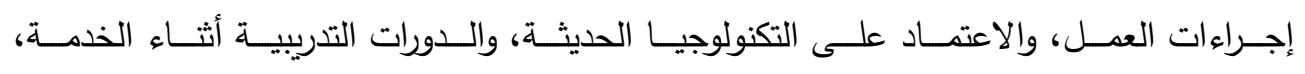

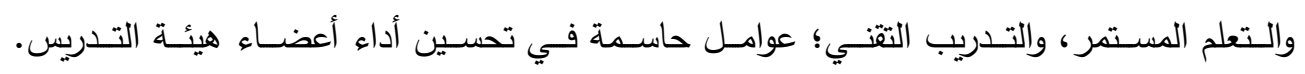


وقـد تثـابهت الدراسـة الحاليـة مـع الدراســة السـابقة في تتاولهـا لموضـوع إدارة المواهـب، ومـنهج

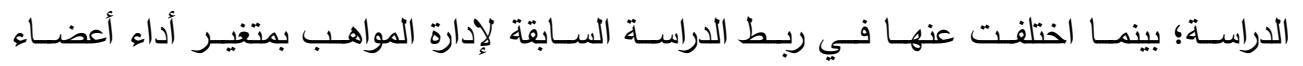
هيئة التدريس، وفي الهدف، والمجتمع، والأداة، وبيئة الدراسة.

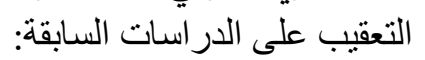

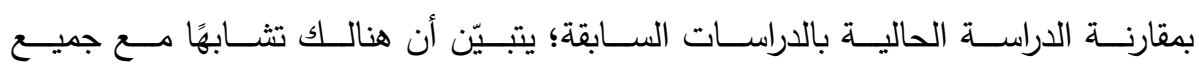

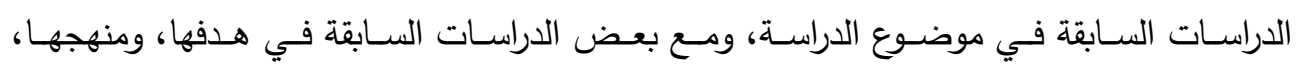

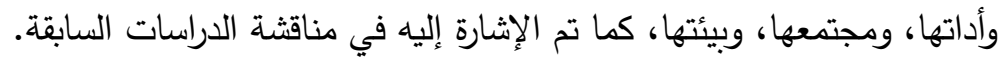

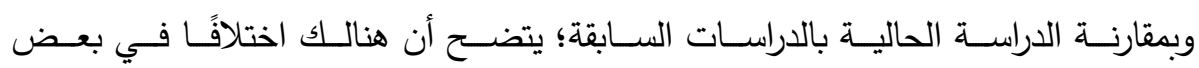

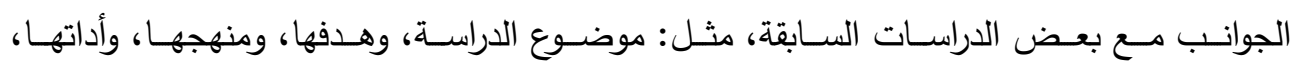
ومجتمعها، وبيئتها، كما تم الإثارة إليه في مناقثة الدراسات السابقة.

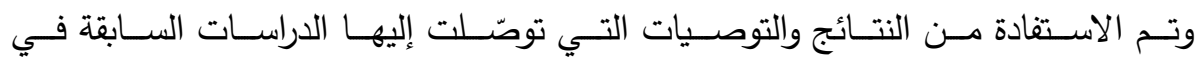

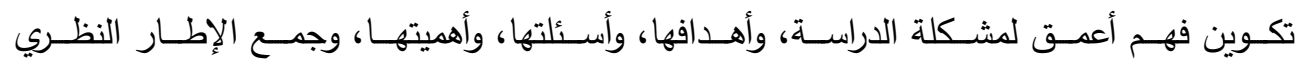

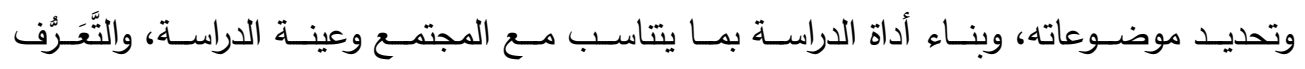

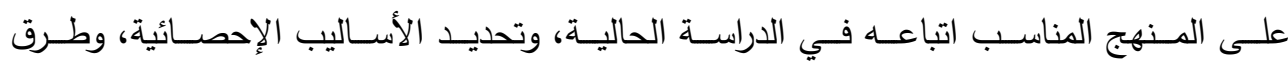

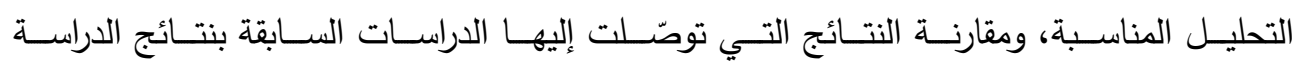
الحالية، ومساعدة الباحثة على تقديم التوصيات والمُقترحات.

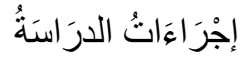

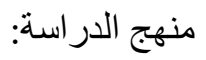

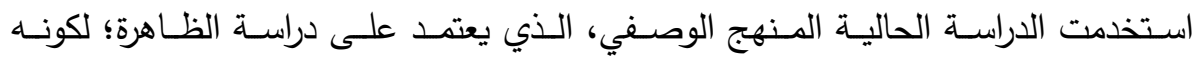

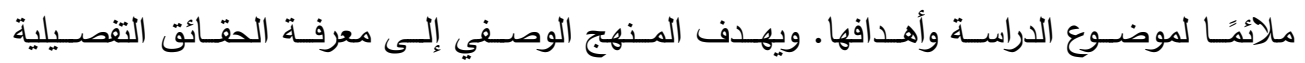

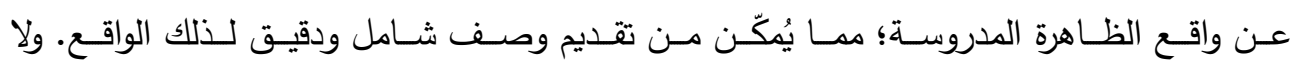

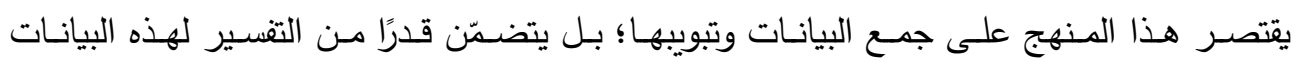

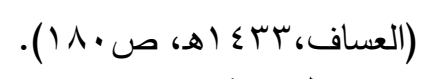

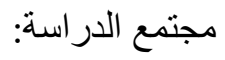

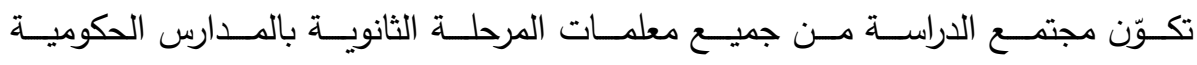

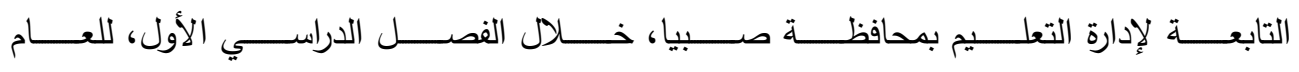

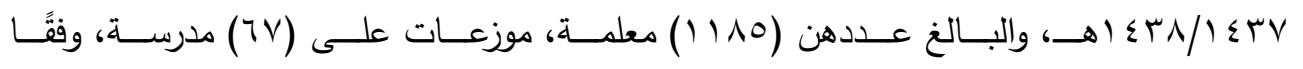


لأحسدث إحصــائية تــم الحصــول عليهـا مـن إدارة التعلـيم بمحافظــة صــبيا، للعـام الدراسـي . هـ $\leqslant \mu / / \leqslant r v$ عينة الدر اسة:

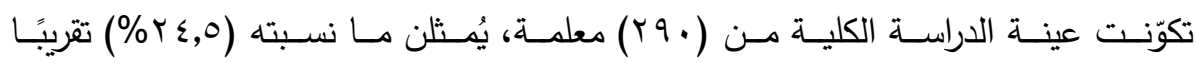
من حجم مجتمع الدراسة, أخترن بالطريقة العشوائية البسيطة.

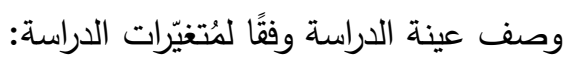

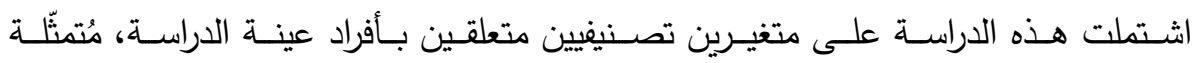

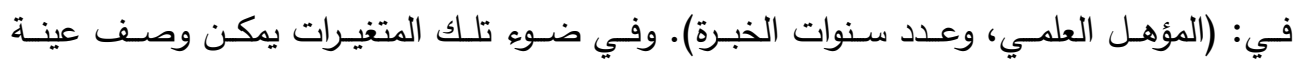

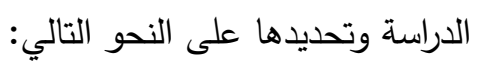

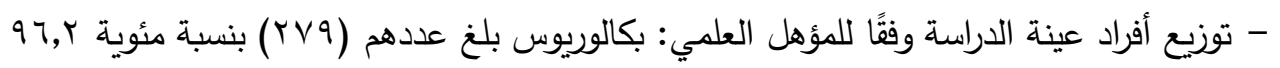

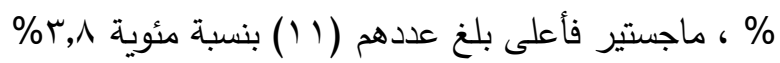

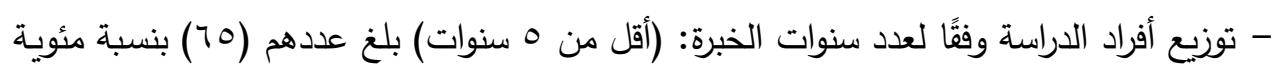

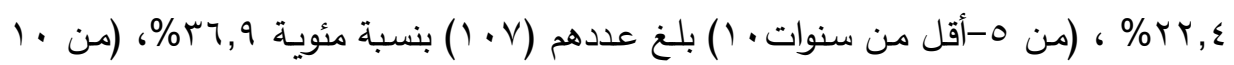

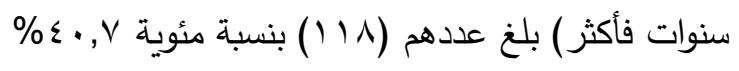

أداة الدر اسة:

أستخدمت الاستبانة بوصفها أداة لجمع البيانات المتعلقة بموضوع الدراسة؛ لأنها أكثر الأدوات البحثية استخدامًا في هذه البحوث، وهو ما يؤكّده عدد من الأدبيات التربوية، وتم بناء الأداة

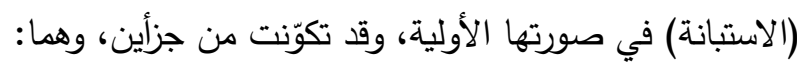
• الجزء الأول: يحوي البيانات الأولية التي اشتملت على متغيرات الدراسة، وهي: الدئ، (المؤهل

$$
\text { العلمي، وعدد سنوات الخبرة). }
$$

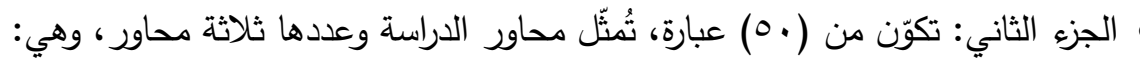
المحور الأول: درجة ممارسة إدارة المواهب المؤسسية لدى قائدات المدارس الثانوية بمنطقة جازان، لهان،

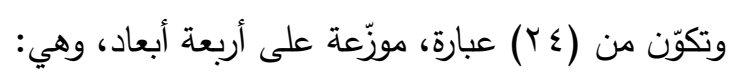

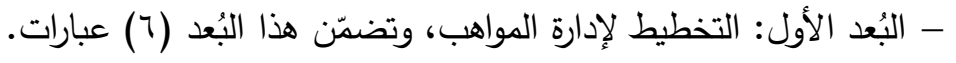
- البُعد الثاني: تدريب المواهب وتطويرها، وتضمّن هذا البُعد (آ) عبارات. - البُعد الثالث: تحفيز المواهب، وتضمّن هذا البُعد (؟) عبارات. - البُعد الرابع: تقويم أداء المواهب، وتضمّن هذا البُعد (T) عبارات. 
المحـور الثـاني: معوقـات ممارسـة إدارة المواهب المؤسسية لدى قائدات المـدارس الثانويـة بمنطقة جازان، وتضمّن هذا المحور (r I ( عبارة. المحور الثالث: المُقترحات التي يمكن أن تُسهم في نجاح ممارسة إدارة المواهب المؤسسية

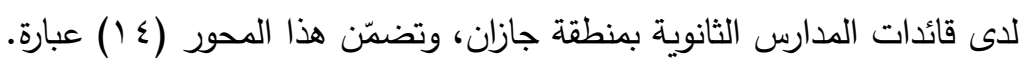
وقد أعتمد الثكل المغلق (Closed Questionnaire)، الذي يحدّد الاستجابات المحتملة لكل سؤال.

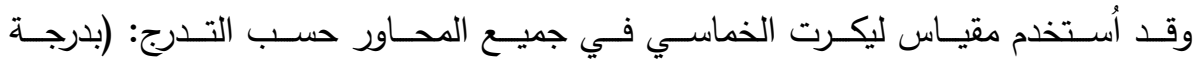

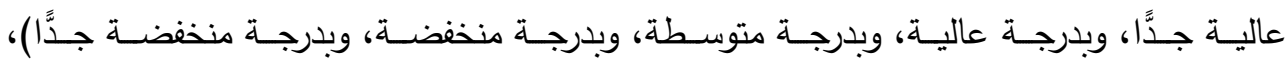

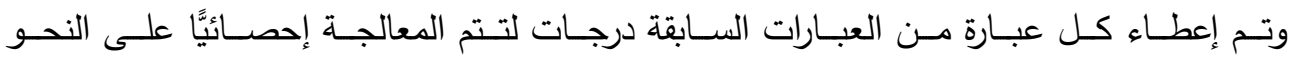

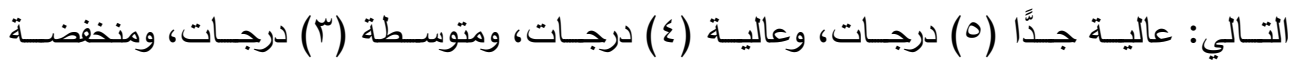

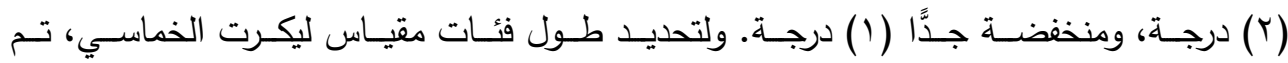

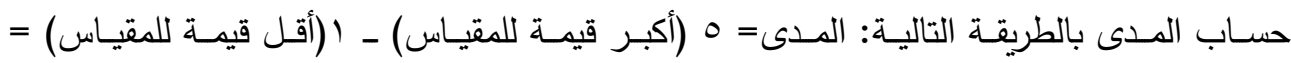

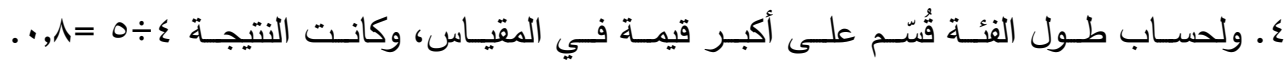

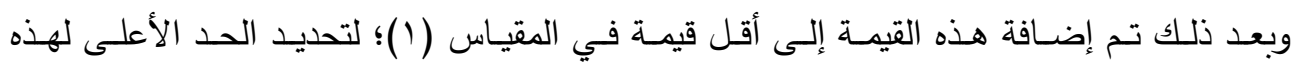
الفئة، • ^, • +1= •^, 1، وبالطريقة نفسها تم تحديد الحدود العليا للفئات المتبقية:

$$
\begin{aligned}
& \text { - من ا إلى • • } 1 \text { (منخفضة جدَّا) }
\end{aligned}
$$

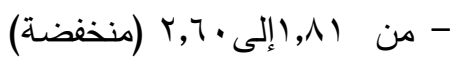

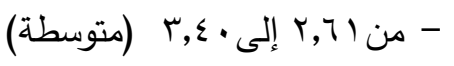

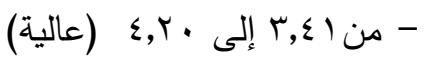

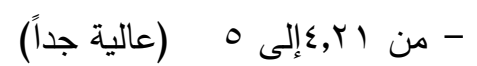

صدق الأداة: تم التحقق من صدق أداة الدراسة من خلال ما يلي:

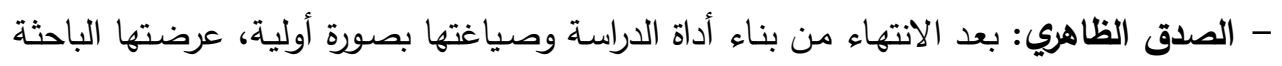

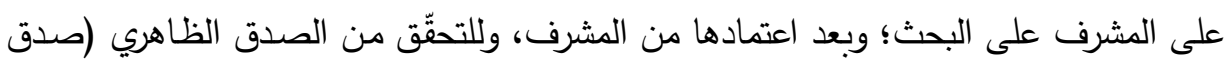

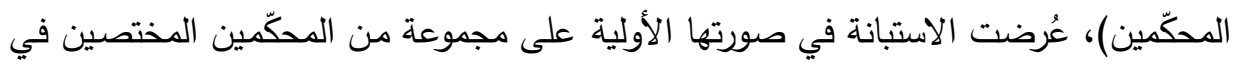
المجال العلمي من أعضاء هيئة التدريس بالجامعات والكليات الحكومية المختلفة داخل المملكة المئه

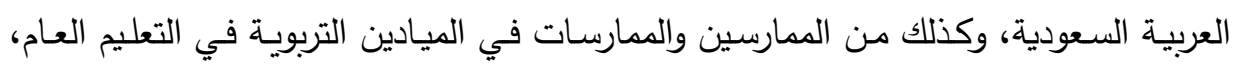

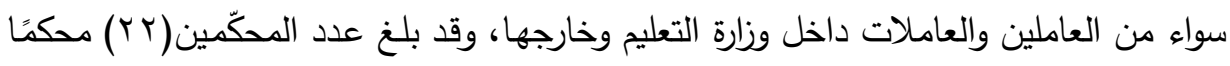


ومحكمة؛ لتحديد مدى وضوح عبارات أداة الدراسة، ومدى انتمائها للمحور الذي تتنمي إليه،

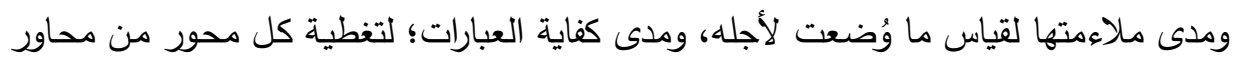

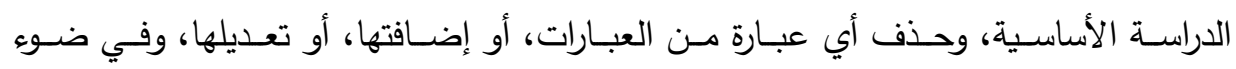

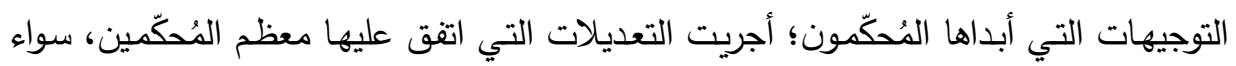

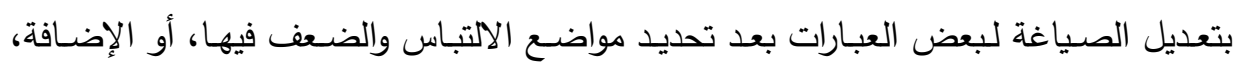
والحذف لبعض العبارات؛ حتى أصبحت الاستبانة في صورتها النهائية.

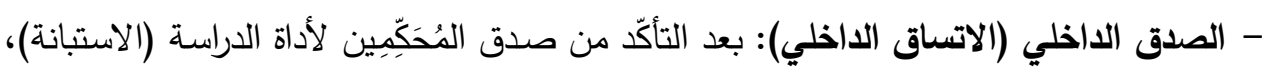

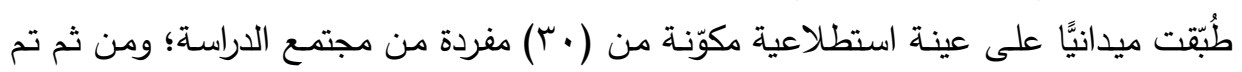

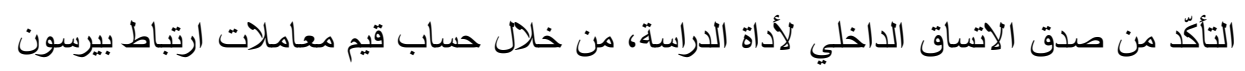

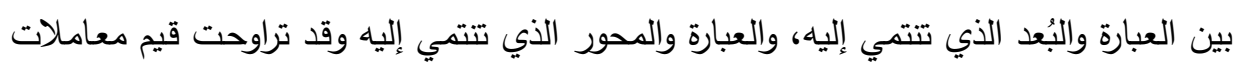

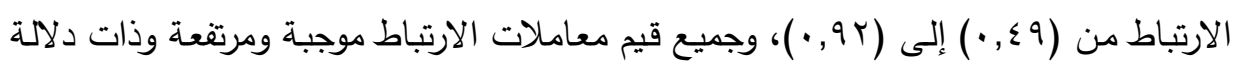
إحصائية عند مستوى ( ال. , ·)، مما يثير إلى وجود علاقة ارتباط موجبة ودالة إحصائيَّا بين

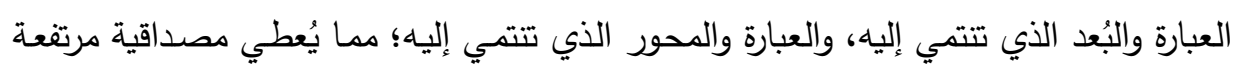

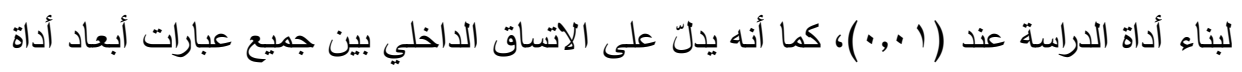

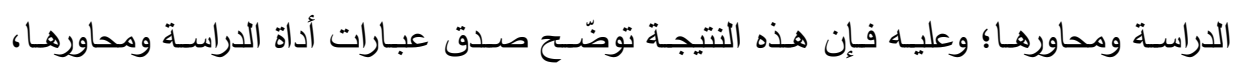

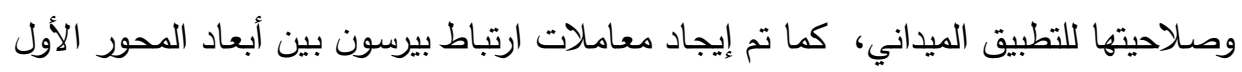

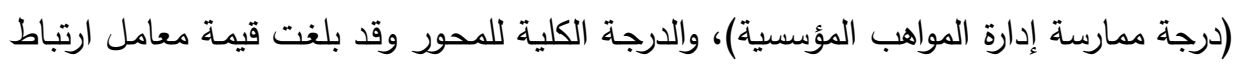

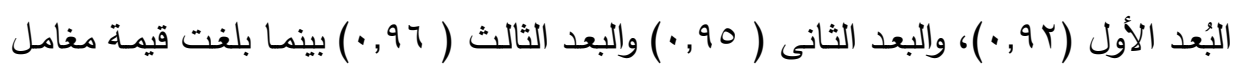
ارتباط البعد الرابع (90, • )، وجميع قيم معاملات الارتباط موجبة ومرتفعة وذات دلالة إحصائية

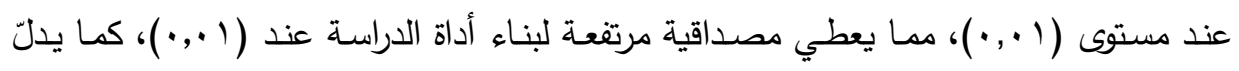

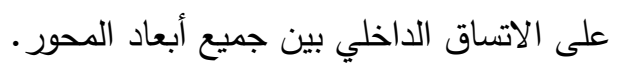
- ثبات الأداة:تم التأكد من ثبات أداة الدراسة بطريقة معامل ألفا كرونباخ، وقد تراوحت قيم معامل

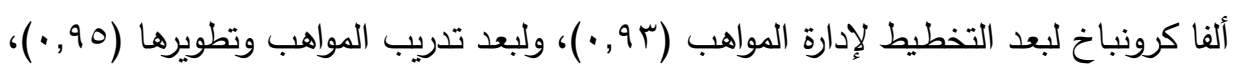

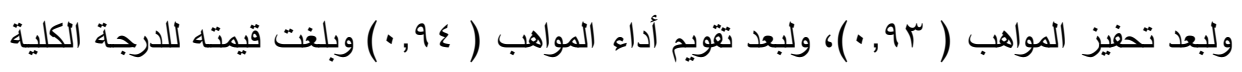

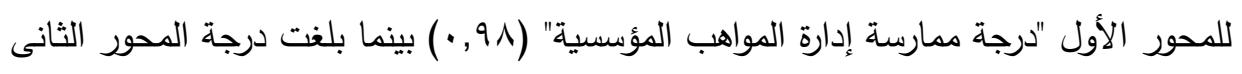

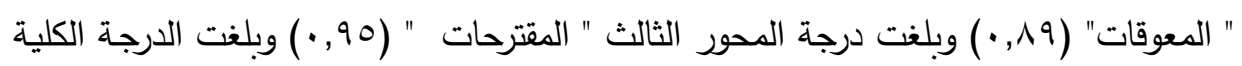

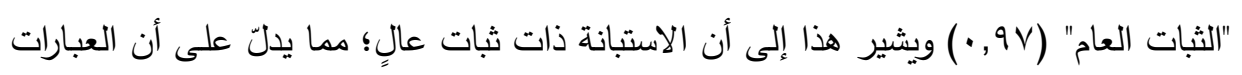


المكوّنة لأبعاد الاستبانة ومحاورها تُعطي نتائج مستقرة وثابتة في حال إعادة تطبيقها على أفراد

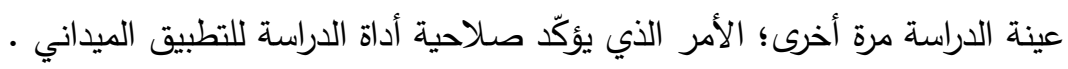

$$
\text { نتائج الدراسة }
$$

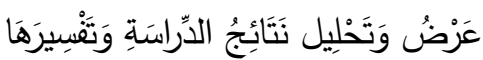

السؤال الأول: ما الأسس النظرية لإدارة المواهب المؤسسية ؟

تمت الإجابة عن هذا السؤال من خلال الإطار النظري.

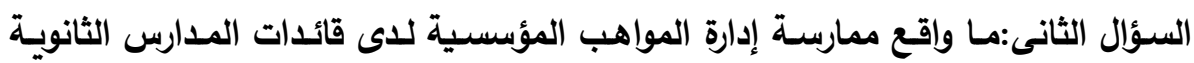

بمنطقة جازان،من وجهة نظر المعلمات؟

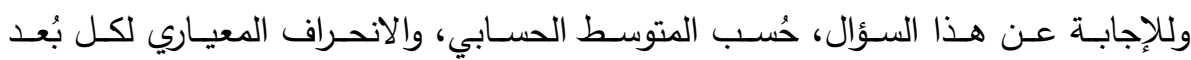

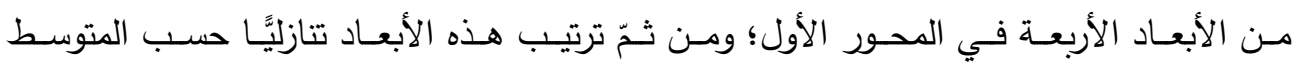
الحسابي لكل بُعد، ويوضّح ذلك جدول رقم (r) التالي: جدول (r):

المتوسطات الحسابية، والانحرافات المعيارية لاستجابات أفراد عينة الدراسة، حول درجة ممارسة

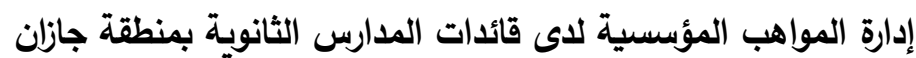

\begin{tabular}{|c|c|c|c|c|c|}
\hline الترتيب & الدرجة & الانحراف المعياري & المتوسط الحسابي & البُعد & م \\
\hline$\varepsilon$ & متوسطة & $\cdot, \leqslant 9$ & r,q & التخطيط لإدارة المواهب & 1 \\
\hline r & متوسطة & $\cdot, \varepsilon \varepsilon$ & r,9० & تدريب المواهب وتطويرها & r \\
\hline r & متوسطة & $\cdot, 0 \leqslant$ & r,97 & تحفيز المواهب & r \\
\hline 1 & متوسطة & $\cdot, \leqslant \wedge$ & $r, .0$ & تقويم أداء المواهب & $\varepsilon$ \\
\hline & متوسطة & $\cdot, \varepsilon$. & r,१V & \multicolumn{2}{|c|}{$\begin{array}{c}\text { المتوسط العام لمحور درجة ممارسة إدارة } \\
\text { المؤسسية لدى قائدات المدارس }\end{array}$} \\
\hline
\end{tabular}

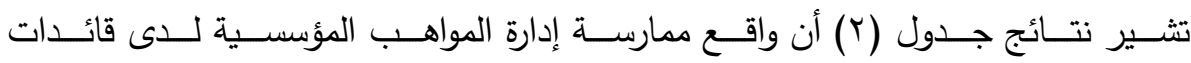

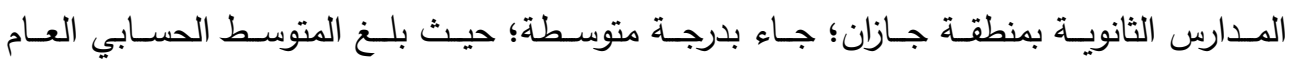

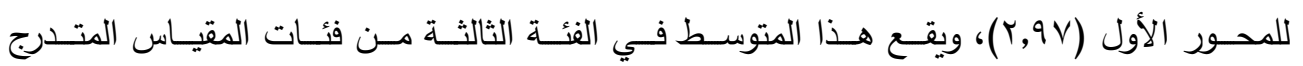

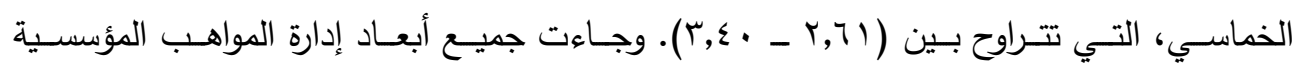

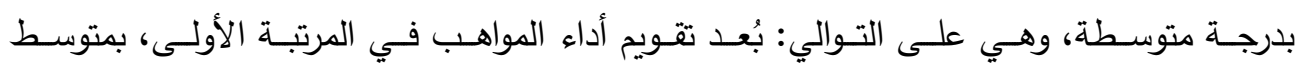




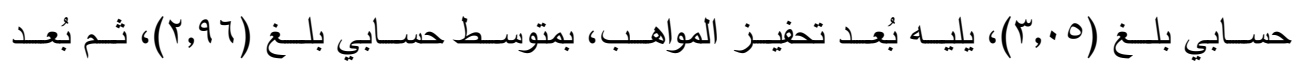

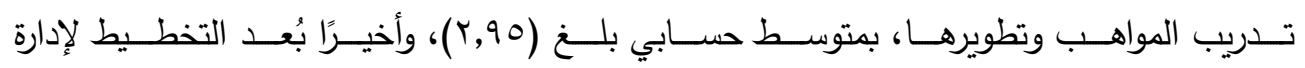

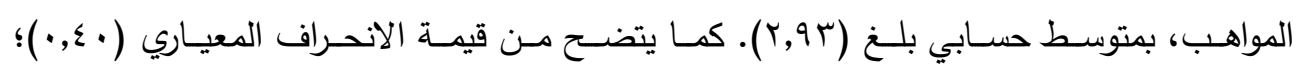

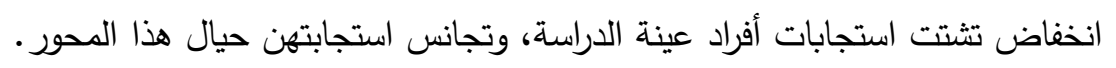

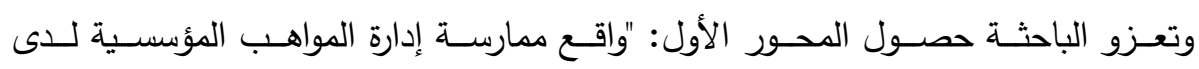

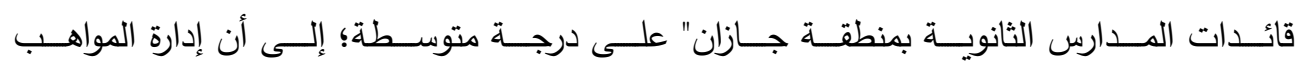

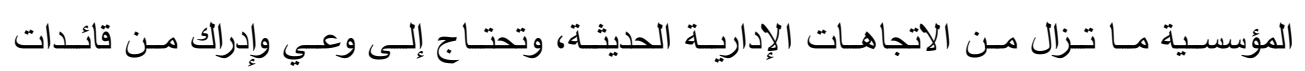

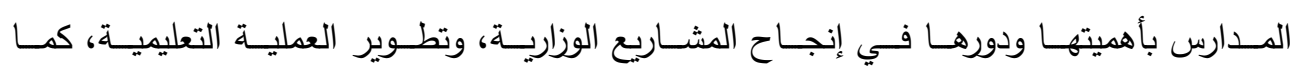

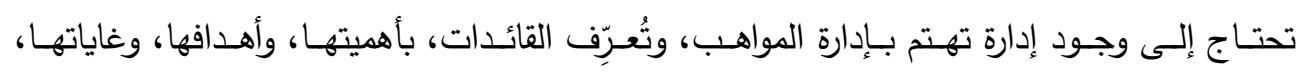

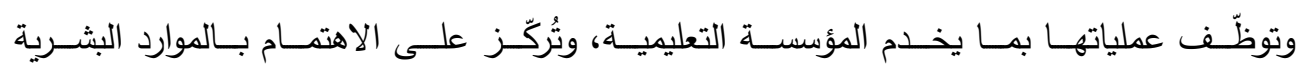

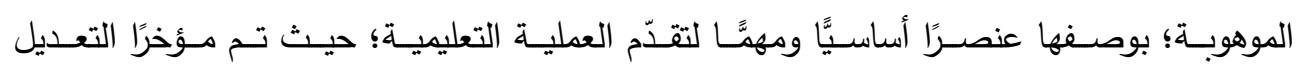

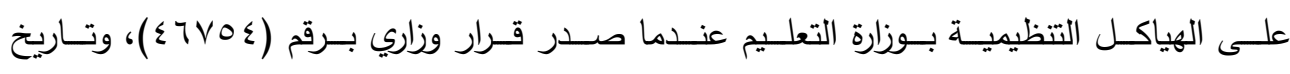

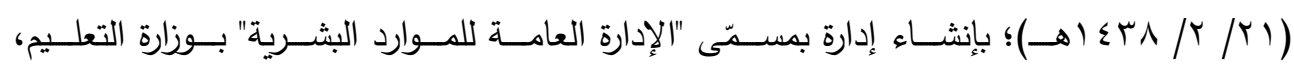

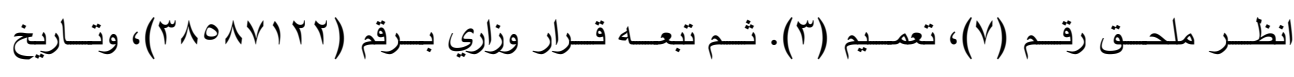

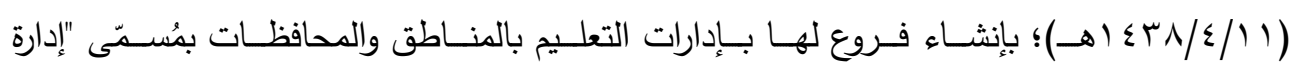

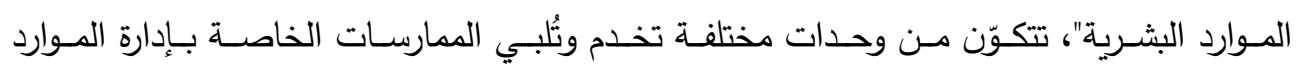

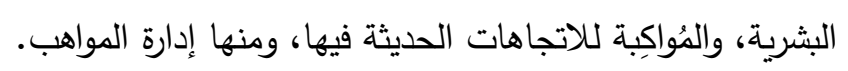

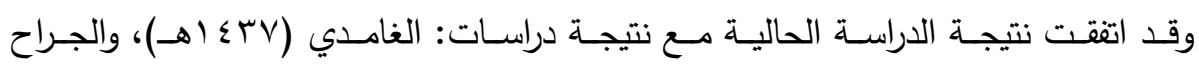

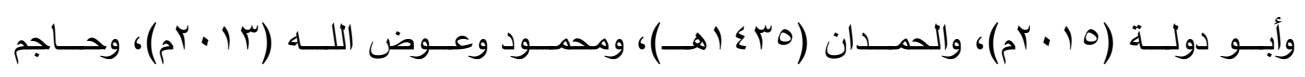

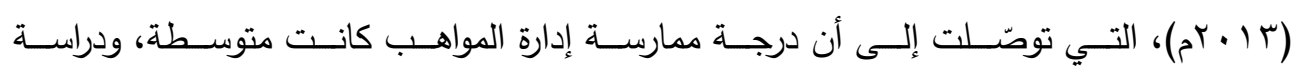

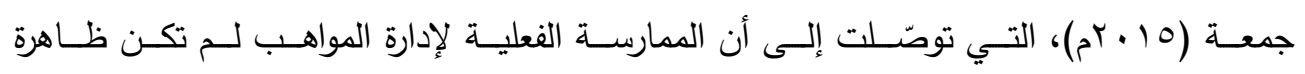

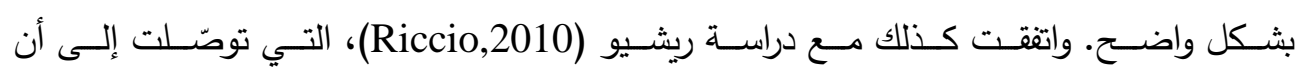

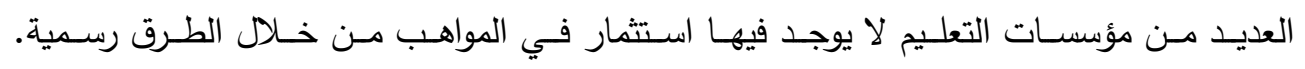

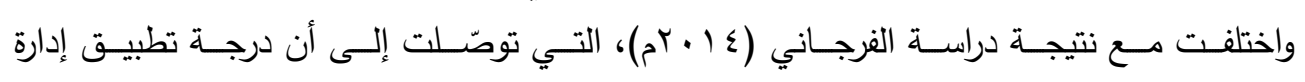

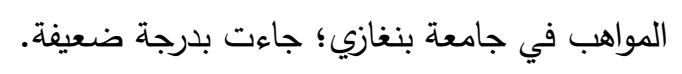

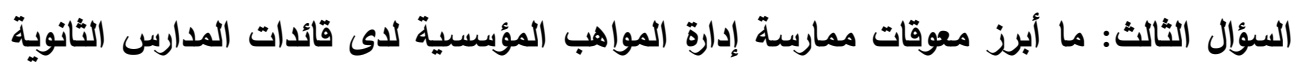

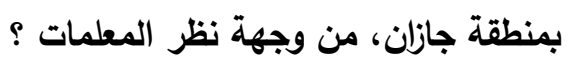


للإجابـة عـن السـؤال، حُسـبت التكـرارات، والنســب المئويـة، والمتوســات الحسـابية،

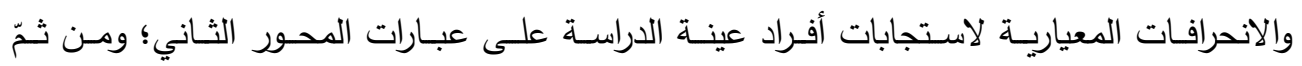
ترتيب هذه العبارات تتازليًا حسب المتوسط الحسابي ، ويوضّح ذلك الجدول التالي: جدول (r):

التكرارات، والنسب المئوية، والمتوسطات الحسابية، والانحرافات المعيارية، لاستجابات أفراد عينة

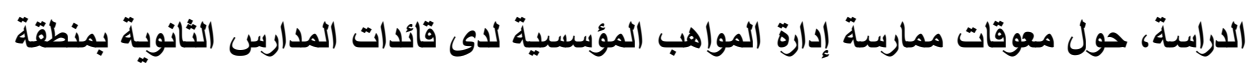

\begin{tabular}{|c|c|c|c|c|c|c|c|c|c|c|}
\hline \multirow[b]{2}{*}{ 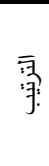 } & \multirow{2}{*}{$\begin{array}{ll}\bar{\lambda} & \overline{3} \\
\frac{7}{9} & \bar{y}\end{array}$} & \multirow{2}{*}{$\begin{array}{l}\overline{\bar{x}} \\
3 \\
\overline{3} \\
\overline{7} \\
3 \\
\overline{3}\end{array}$} & \multicolumn{5}{|c|}{ درجة التوافر } & \multirow{2}{*}{\multicolumn{2}{|c|}{ 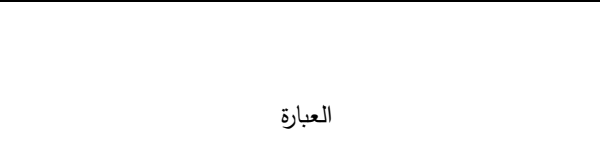 }} & \multirow[b]{2}{*}{ r } \\
\hline & & & $:{ }^{3}{ }^{3}=1$ & :3ู & 吾 & 产: & 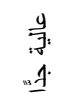 & & & \\
\hline \multirow{2}{*}{11} & \multirow{2}{*}{$•, 99$} & \multirow{2}{*}{$r, 01$} & $1 \leq$ & דו & 10 & $1 \times 9$ & דr & ت & \multirow{2}{*}{ ضعف اهتمام وزارة التعليم بمواهب المعلمات. } & \multirow[b]{2}{*}{1} \\
\hline & & & $\varepsilon, \wedge$ & 9 & $r q, r$ & $\varepsilon \leqslant, 0$ & $1 Y, \Sigma$ & $\%$ & & \\
\hline \multirow{2}{*}{$\varepsilon$} & \multirow{2}{*}{ •, } & \multirow{2}{*}{$r, \wedge \Lambda$} & V & IV & or & $1 \leqslant r$ & vi & $ت$ & \multirow{2}{*}{ غموض مفهوم إدارة المواهب لدى قائدة المدرسة. } & \multirow{2}{*}{$r$} \\
\hline & & & $r, \varepsilon$ & 0,9 & $1 v, q$ & $\varepsilon q, r$ & $r \leqslant, 0$ & $\%$ & & \\
\hline \multirow{2}{*}{1.} & \multirow{2}{*}{$\cdot, 9 \vee$} & \multirow{2}{*}{ r,ד } & 1. & זr & vr & & 0. & ت & \multirow{2}{*}{ ضعف اهتمام قائدة المدرسة بإدارة مواهب المعلمات. } & \multirow{2}{*}{$r$} \\
\hline & & & r,乏 & $\mathrm{v}, q$ & $r 0, r$ & $\varepsilon \tau, r$ & $I V, r$ & $\%$ & & \\
\hline \multirow{2}{*}{$\wedge$} & \multirow{2}{*}{ •, १. } & \multirow{2}{*}{$r, V r$} & r & $r \leq$ & $\wedge \varepsilon$ & Tr & or & $ت$ & \multirow{2}{*}{ اتباع الأساليب الإدارية التقليدية في قيادة المدرسة. } & \multirow{2}{*}{$\varepsilon$} \\
\hline & & & $\cdot, \mathrm{V}$ & $\Lambda, r$ & $r q, \cdot$ & $\varepsilon r, \varepsilon$ & $19, v$ & $\%$ & & \\
\hline \multirow{2}{*}{$r$} & \multirow{2}{*}{$\cdot, 9 \wedge$} & \multirow{2}{*}{$r, 99$} & v & iv & $\leqslant 9$ & $11 \mathrm{~V}$ & $1 \cdots$ & $ت$ & \multirow{2}{*}{ قلة برامج تدريب قائدة المدرسة في إدارة المواهب. } & \multirow{2}{*}{0} \\
\hline & & & $r, \varepsilon$ & 0,9 & 17,9 & $\varepsilon \cdot, r$ & $r \varepsilon, 0$ & $\%$ & & \\
\hline 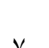 & 94 & $r y<$ & v & r) & $\wedge$. & 111 & 79 & $ت$ & ضعف ملاءمة الثقافة التتظيمية السائدة في المدرسة لإدارة & 1 \\
\hline $\mathrm{r}$ & י & $1,1,2$ & $r, \varepsilon$ & $\mathrm{V}, \mathrm{r}$ & $r V, T$ & rq,. & $r+\Lambda$ & $\%$ & 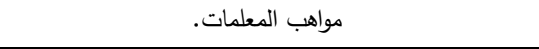 & r \\
\hline & & & $\varepsilon$ & 10 & $0 \leqslant$ & IrA & $\wedge 9$ & $ت$ & & \\
\hline r & $\cdot, 91$ & r,91 & $1, \varepsilon$ & $0, r$ & $1 \wedge, 7$ & $\varepsilon \varepsilon, 1$ & $r \cdot, v$ & $\%$ & كترة الاعباء الإدارية الموكا & $\mathrm{v}$ \\
\hline & & & r & $\varepsilon r$ & $11 r$ & 10 & $\leq 7$ & $ت$ & & \\
\hline 11 & $\cdot, 41$ & 1,22 & $1, \cdot$ & $1 \leqslant, \wedge$ & rq,. & rq, r & 10,9 & $\%$ & لـه المعلمات الموهوبات في المدرسه. & 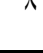 \\
\hline 9 & פ & rTy & - & r & ז & 1.7 & 7. & $ت$ & اهتمام قائدة المدرسة بعدد سنوات خدمة المعلمة أكثر من & 9 \\
\hline 1 & ו & , & - & $1 \cdot, v$ & r., & ד, דז & $r \cdot, v$ & $\%$ & موهبتها. & 1 \\
\hline 0 & 96 & $\mathrm{rat}$ & 1 & 19 & $\wedge \wedge$ & 90 & NV & $ت$ & y & 1 \\
\hline 管 & , & , & ., r & 7,7 & $r \cdot r$ & & $r \cdot, \cdot$ & $\%$ & 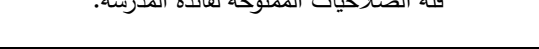 & 1. \\
\hline & & & 1 & 9 & rv & IrA & 11. & $ت$ & & \\
\hline 1 & $\cdot, 4$ & 2,11 & r., & $r, 1$ & $M, \Lambda$ & $\leqslant \leqslant, 1$ & $r v, q$ & $\%$ & قلة المخصصات المالية اللازمة لإدارة مواهب المعلمات. & 11 \\
\hline 1 & $\cdot, \wedge 9$ & $r, \wedge \varepsilon$ & $\circ$ & 9 & $\wedge \varepsilon$ & $|r|$ & $v_{1}$ & $ت$ & قلة توافر المقاييس المساعدة على اكتشاف مواهب المعلمات. & ir \\
\hline
\end{tabular}




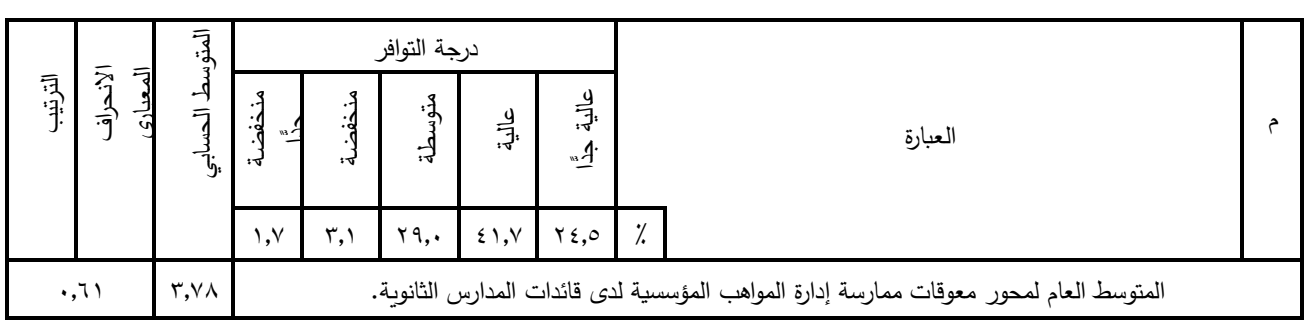

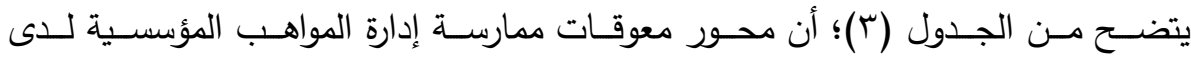

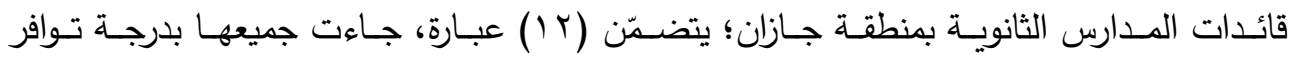

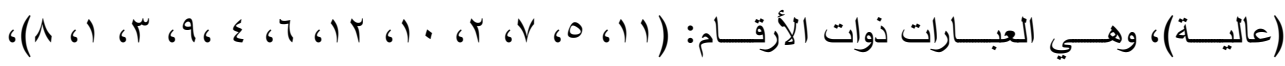
ورتُبـت تتازليَّا حسـب الموافقـة مـن وجهـة نظـر أفـراد عينـة الدراسـة؛ حيـث جـاءت متوسـطاتها الحســ ورلـ

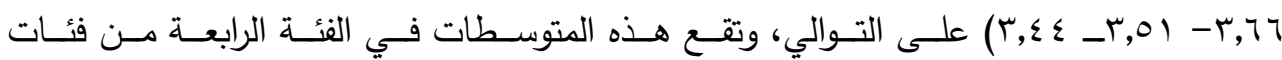

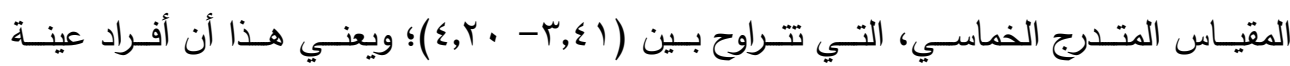

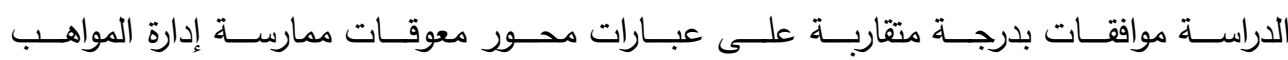

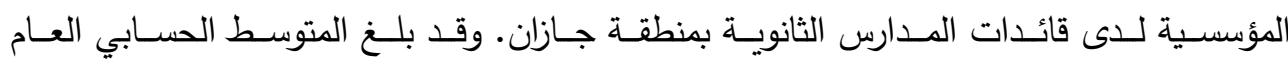

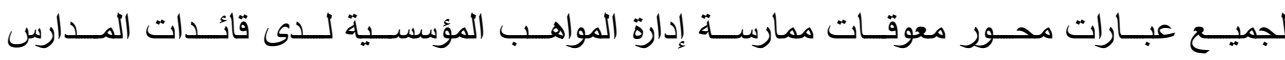

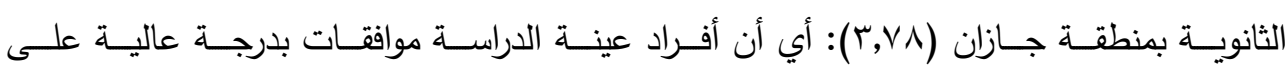

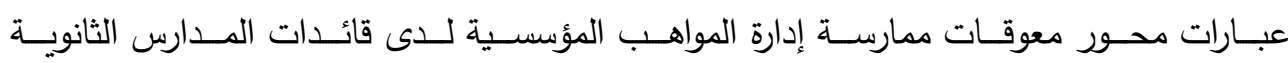
بمنطقة جازان.

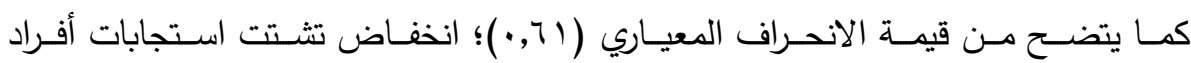

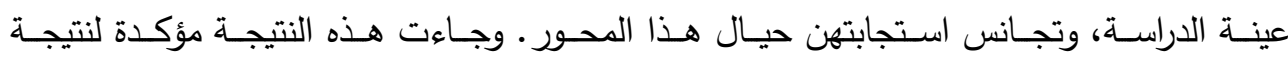

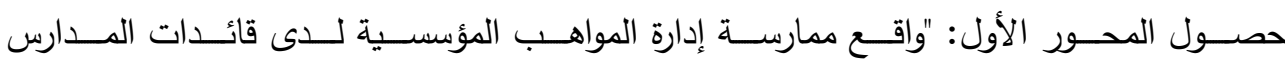

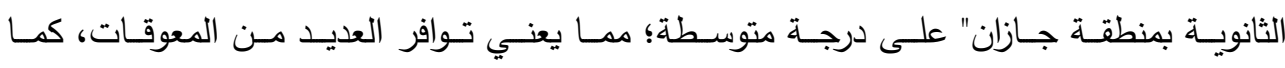

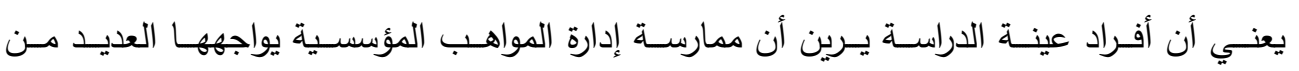

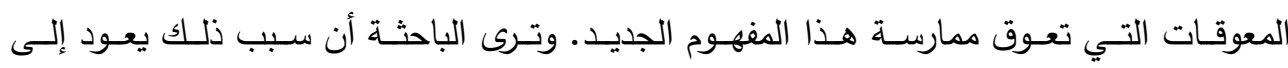

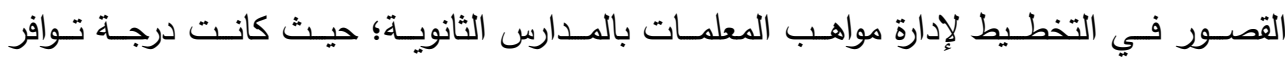

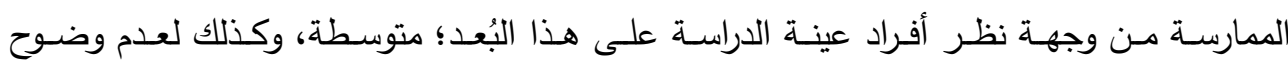

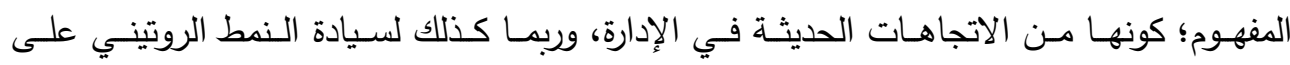

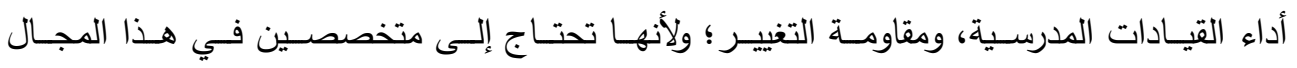


يقومـون بـدعم القيـادات المدرسـية فـي وضــع البـرامج المناسـبة، إضــافة إلـى أنـهـ مـع وجـود

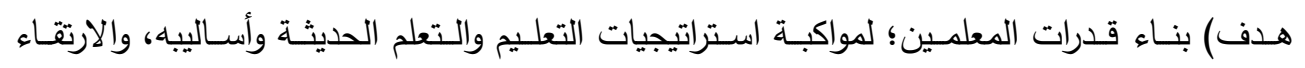

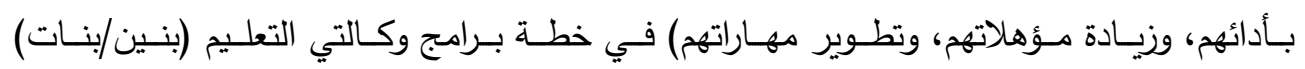

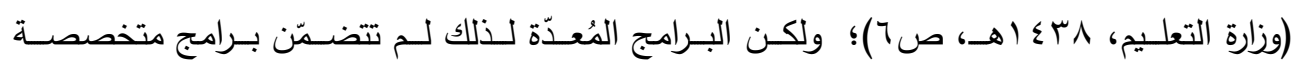

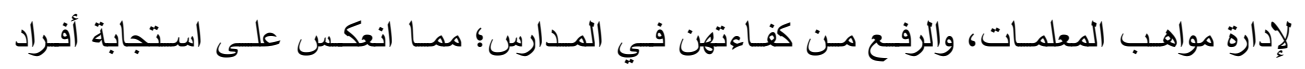
عينة الدراسة لعبارات محور المعوقات.

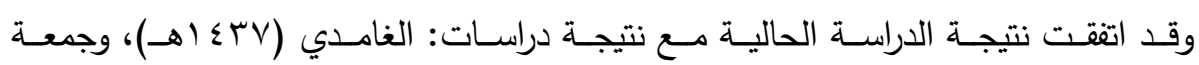

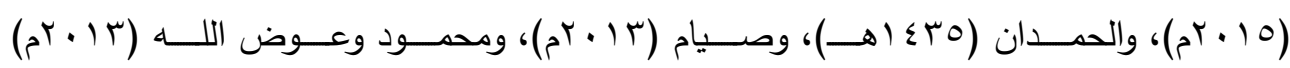

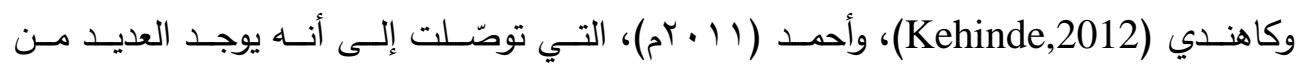

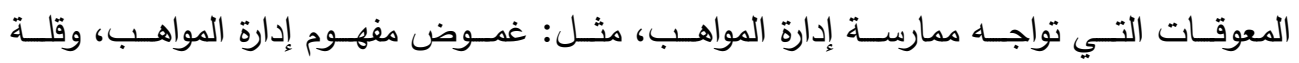

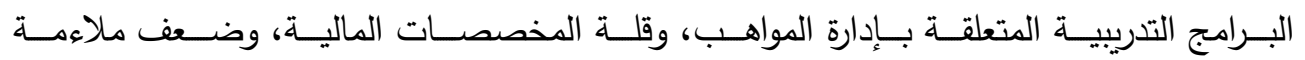
الثقافة التظظيمية التي تدعم إدارة المواهب. السؤال الرابع: ما أهم المُقترحات التي يمكن أن تُسهم في نجاح ممارسة إدارة المواهب المؤسسية

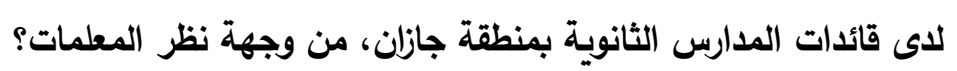

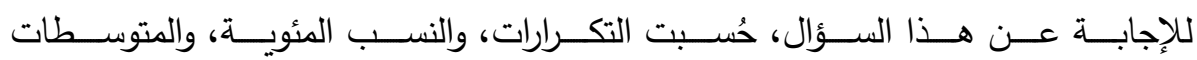

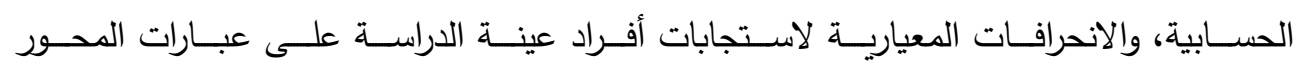

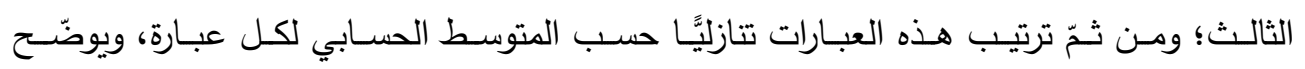

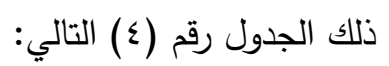

\section{جدول (؛ ):}

التكرارات، والنسب المئوية، والمتوسطات الحسابية، والانحرافات المعيارية، لاستجابات أفراد عينة

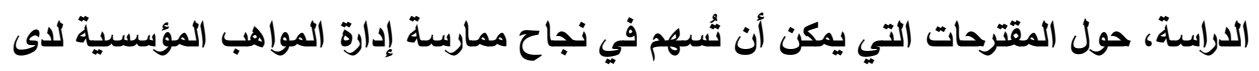
قائدات المدارس الثانوبة بمنطقة جازئ فئان

\begin{tabular}{|c|c|c|c|c|c|c|c|c|c|c|}
\hline \multirow[b]{2}{*}{ 䨪: } & \multirow[b]{2}{*}{ 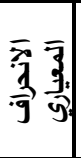 } & \multirow[b]{2}{*}{$\begin{array}{l}\overline{7} \overline{3} \\
3 \\
3\end{array}$} & \multicolumn{5}{|c|}{ درجة الأهمية } & \multirow{2}{*}{\multicolumn{2}{|c|}{ العبارة }} & \multirow[b]{2}{*}{ b } \\
\hline & & & 得 & : & 承 & $\frac{9}{7}$ & 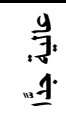 & & & \\
\hline \multirow{2}{*}{$\varepsilon$} & \multirow{2}{*}{., 91} & \multirow{2}{*}{ r,qА } & 9 & $1 \pi$ & M & 109 & $\mathrm{VA}$ & $ت$ & \multirow{2}{*}{ اهتمام وزارة التعليم بمواهب المعلمات. } & \multirow{2}{*}{1} \\
\hline & & & $r, 1$ & $\varepsilon, 0$ & $1,, v$ & $0 \leqslant, \Lambda$ & rq,q & $\%$ & & \\
\hline \multirow{2}{*}{$r$} & \multirow{2}{*}{$\cdot, \wedge 9$} & \multirow{2}{*}{$\varepsilon, \cdot 1$} & $\varepsilon$ & 17 & $\varepsilon$. & $1 \leqslant r$ & $\Lambda \Lambda$ & ت & \multirow{2}{*}{ تتمية الوعي للى قائدات المدارس بأهمية إدارة } & \multirow{2}{*}{ r } \\
\hline & & & $1, \varepsilon$ & 0,0 & $1 T, \Lambda$ & $\varepsilon 9, \cdot$ & $r \cdot, r$ & $\%$ & & \\
\hline r & $\cdot, 10$ & $\varepsilon, 1 \varepsilon$ & 0 & 1. & ז & $1 \leqslant V$ & $1 . r$ & ت & إعداد برامج تدربيية لقائدات المدارس في إدارة & $r$ \\
\hline
\end{tabular}




\begin{tabular}{|c|c|c|c|c|c|c|c|c|c|c|}
\hline \multirow{3}{*}{ 震: } & \multirow{3}{*}{ 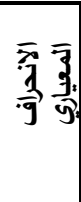 } & \multirow{3}{*}{ 牙示 } & \multicolumn{5}{|c|}{ درجة الأهمية } & \multirow{2}{*}{\multicolumn{2}{|c|}{ العبارة }} & \multirow{3}{*}{ م } \\
\hline & & & $: 3$ & : & 趂 & 产: & "1. & & & \\
\hline & & & $1, v$ & $r, \varepsilon$ & 9 & $0 ., \mathrm{V}$ & ro,r & $\%$ & المواهب. & \\
\hline \multirow{2}{*}{$\wedge$} & \multirow{2}{*}{, १९ } & \multirow{2}{*}{ r,q. } & $\Lambda$ & $r$. & $\varepsilon \varepsilon$ & Ir & ᄉ. & ت & \multirow{2}{*}{ بناء الثقافة التظظيمية الملاءمة لممارسة إدارة مواهب المبل } & \multirow{2}{*}{$\varepsilon$} \\
\hline & & & $r, \wedge$ & 7,9 & $10, Y$ & $\varepsilon \vee, 1$ & $r V, T$ & $\%$ & & \\
\hline \multirow{2}{*}{ v } & \multirow{2}{*}{, 97} & \multirow{2}{*}{ r,q. } & V & YI & $\leq 7$ & 1150 & 11 & $ت$ & \multirow{2}{*}{ تعاون قائدات المدارس فمع الوحدات المعنية بالتتمية } & \multirow{2}{*}{0} \\
\hline & & & $r, \varepsilon$ & $V, r$ & 10,9 & $\leqslant 7,7$ & $r v, q$ & $\%$ & & \\
\hline \multirow{2}{*}{11} & \multirow{2}{*}{$\cdot, 91$} & \multirow{2}{*}{$\Upsilon, \wedge \varepsilon$} & 1. & 10 & $\varepsilon 1$ & 171 & 07 & $ت$ & \multirow{2}{*}{ عقد شراكات مع مؤسسات المجتمع المعنية برعاية } & \multirow{2}{*}{7} \\
\hline & & & $r, \varepsilon$ & $0, r$ & $1 \leqslant, 1$ & $0 v, 9$ & $19, r$ & $\%$ & & \\
\hline \multirow{2}{*}{1.} & \multirow{2}{*}{$\cdot, 9 \vee$} & \multirow{2}{*}{ r,^० } & $\Lambda$ & 19 & 00 & $1 \pi \varepsilon$ & $V \varepsilon$ & $ت$ & \multirow{2}{*}{ اهتمام قائدات المدارس بتتفيذ برامج لتطوير مواهب } & \multirow{2}{*}{ V } \\
\hline & & & $r, \wedge$ & 7,7 & $19,$. & $\varepsilon 7, r$ & $r 0,0$ & $\%$ & & \\
\hline \multirow{2}{*}{ ir } & \multirow{2}{*}{$\cdot, 99$} & \multirow{2}{*}{ r,یז } & Ir & $1 \varepsilon$ & 01 & ITr & $V \varepsilon$ & $ت$ & \multirow{2}{*}{ إشراك المعلمات الموهوبات في صياغة خطط } & \multirow{2}{*}{$\wedge$} \\
\hline & & & $\varepsilon, 1$ & $\varepsilon, \Lambda$ & $r_{\cdot, \cdot}$ & $\leqslant 0,0$ & $r 0,0$ & $\%$ & & \\
\hline r & .91 & r.Ar & 1. & $1 \varepsilon$ & 79 & ITr & $V \varepsilon$ & $ت$ & جعل التخطيط لإدارة مواهب المعلمات جزءًا من & 9 \\
\hline & & & $r, \varepsilon$ & $\varepsilon, \Lambda$ & $r r, \Lambda$ & $\varepsilon r, \varepsilon$ & ro,o & $\%$ & Htan- & \\
\hline 9 & 9 & & $\wedge$ & 1. & $v_{1}$ & Mr & vo & $ت$ & تشجيع المعلمات على المنافسة للحصول على جوائز & 1 \\
\hline & •, या & r,^т & $r, \wedge$ & $r, \Sigma$ & $r \leqslant, 0$ & $\varepsilon r, \varepsilon$ & ro,9 & $\%$ & 4 & 1. \\
\hline $1<$ & $9 \times$ & $\mathrm{r}$ & 9 & 17 & 71 & $1 \times 4$ & $\mathrm{VI}$ & $ت$ & تضمين مجال إدارة المواهب في استمارة تقويم الأداء & 11 \\
\hline 12 & • & (1, & $r, 1$ & 0,0 & $r+\varepsilon$ & $\varepsilon r, \varepsilon$ & $r \leqslant, 0$ & $\%$ & الوظيفي لقائدات آلّمدارس. & \\
\hline 7 & .91 & $r .97$ & $\Lambda$ & 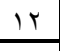 & 71 & 111 & 91 & $ت$ & | منح قائدات المدارس مزيد من الصلاحيات؛ بما يعزّز & Ir \\
\hline & & & $r, \wedge$ & $\varepsilon, 1$ & $r, \cdot$ & $r \wedge, r$ & 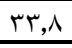 & $\%$ & إدارة مواهب المعلمات. & $\pi$ \\
\hline 1 & 90 & $\leqslant 17$ & $\mathrm{v}$ & IT & r & 117 & $1 \mathrm{Kr}$ & $ت$ & |توفير مخصصات مالية مناسبة للمدارس لإدارة مواهب & سן \\
\hline & $\cdot, 40$ & & $r, \Sigma$ & $\varepsilon, 1$ & $11, \cdot$ & $\varepsilon \cdot, \cdot$ & $\varepsilon r, \varepsilon$ & $\%$ & 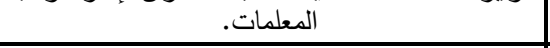 & \\
\hline 0 & 9 & rgy & $\varepsilon$ & 9 & $\mathrm{ve}$ & 117 & 91 & $ت$ & | إعداد الجهات المعنية مقاييس خاصة لاكتثاف مواهب & $1 \leqslant$ \\
\hline & & & $1, \varepsilon$ & $r, 1$ & $r \leqslant, 1$ & $\varepsilon \cdot, \cdot$ & $M, \varepsilon$ & $\%$ & 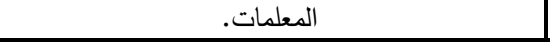 & \\
\hline & $v \varepsilon$ & r,qr & & 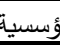 & 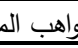 & 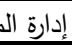 & 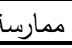 & نجا- & المتوسط العام لمحور المقترحات التى يمكن أن تسهح في & \\
\hline
\end{tabular}

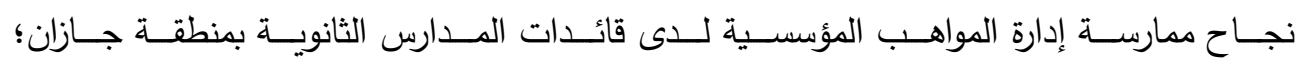

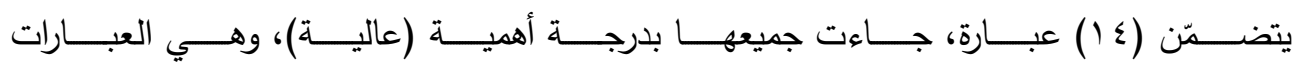

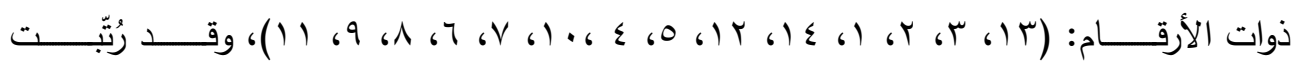

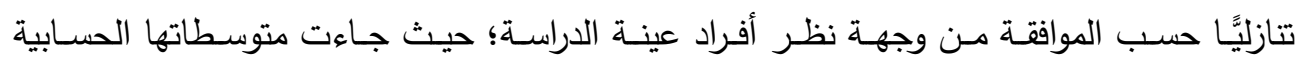

$$
-\wedge 0,-r, \wedge \uparrow-r, 9 .-r, 9 .-r, 9 \uparrow-r, 9 \vee-r, 9 \Lambda-\varepsilon, .1-\varepsilon, 1 \leq-\varepsilon, 1 \uparrow)
$$

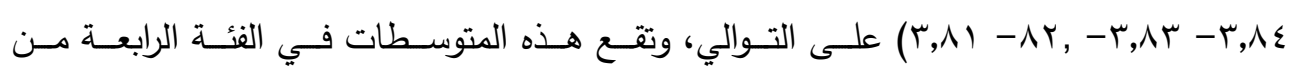

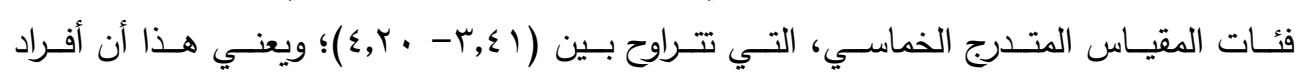

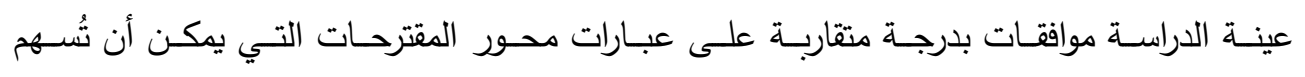


فـي نجـاح ممارســة إدارة المواهـب المؤسسـية لـدى قائـدات المــارس الثانويـة بمنطقــة جـازان.

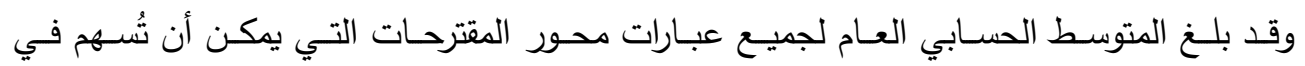

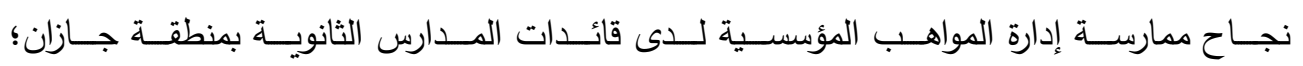

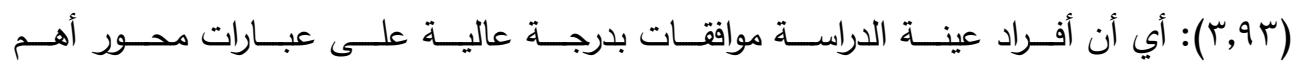

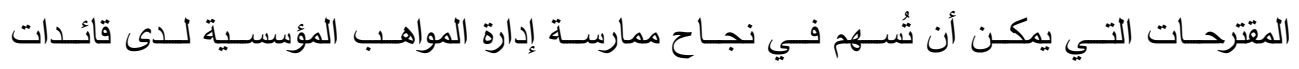
المدارس الثانوية بمنطقة جازان.

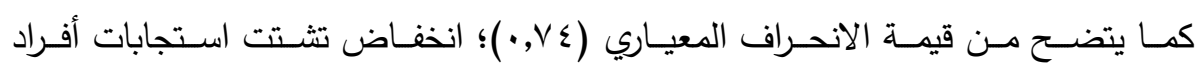

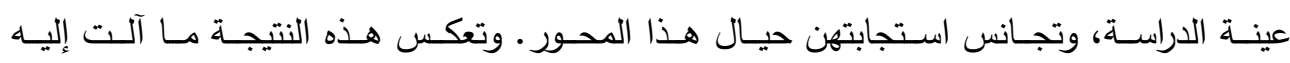

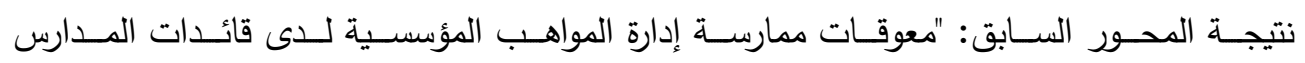

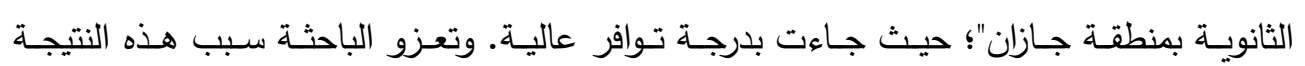

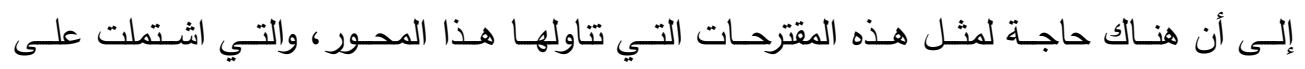

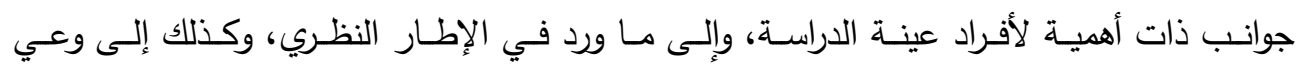

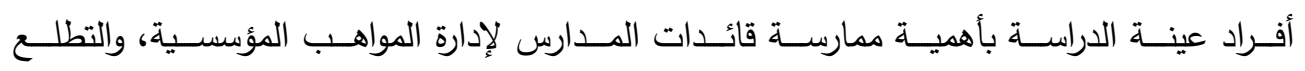

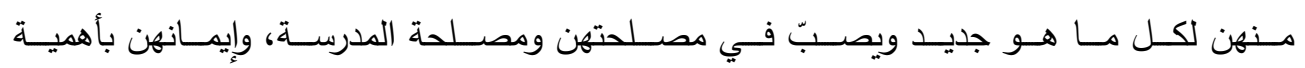

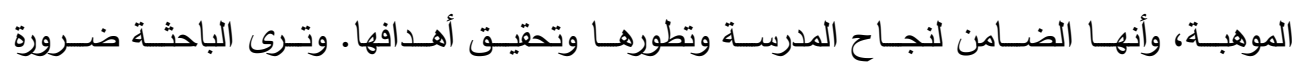

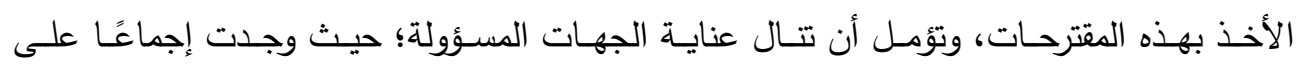

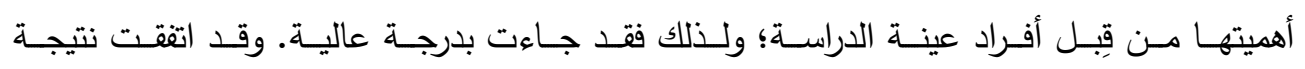

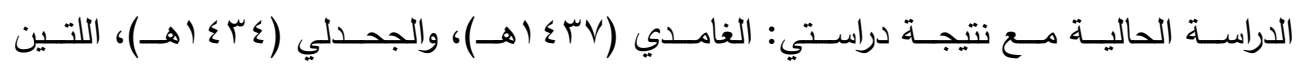
توصّلتا إلى أن متطلبات ممارسة إدارة المواهب جاءت بدرجة دالئ عالية. إجابة السؤال الخامس: هل توجد فروق ذات دلالة إحصائية عند مستوى الدلالة (ه . ..)،

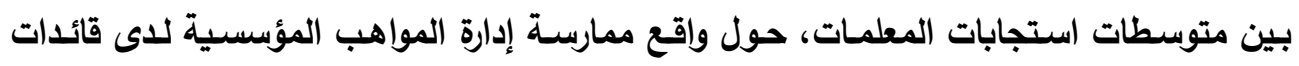

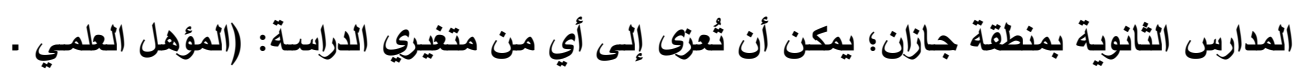
عدد سنوات (الخبرة)؟ وللإجابـة عـن هـــا السـؤال، تـم اســخدام اختبـار (ت) (T-test)؛ لبيـان مـــا إذا كـان

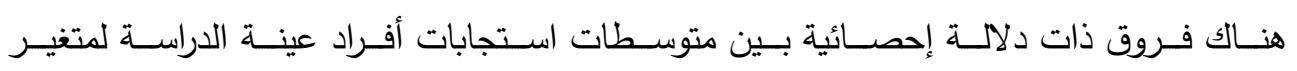

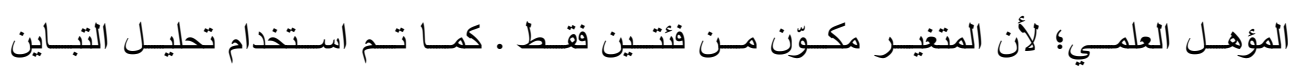




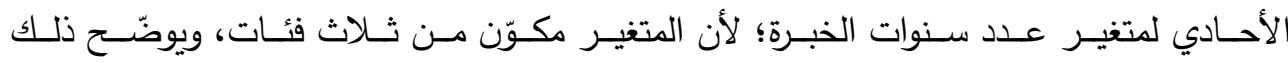

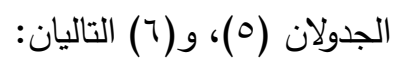

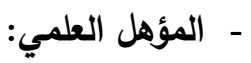

جدول رقم (0): نتائج اختبار (ت)، للفروق بين متوسطات استجابات أفراد عينة الاراسة،

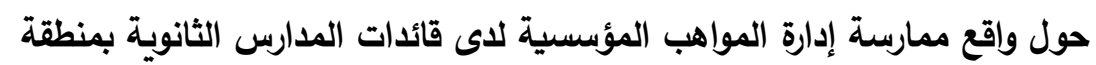

\begin{tabular}{|c|c|c|c|c|c|c|}
\hline مستوى & قيمة & 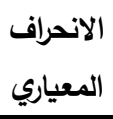 & المتوسط & العدد & المؤهل & البُعد \\
\hline \multirow[b]{2}{*}{$\cdot, T \vee V$} & \multirow[b]{2}{*}{$\cdot, \leqslant r$} & $\cdot, \varepsilon$. & r,q1 & rVq & بكالوريوس & \multirow{2}{*}{ الدرجة الكلية لمحور واقع ممارسة إدارة } \\
\hline & & • & $r, 9 r$ & 11 & فأسستير & \\
\hline
\end{tabular}

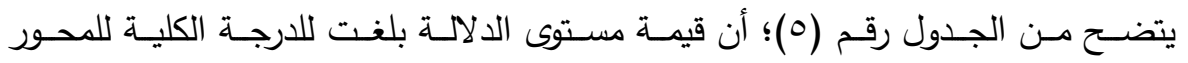

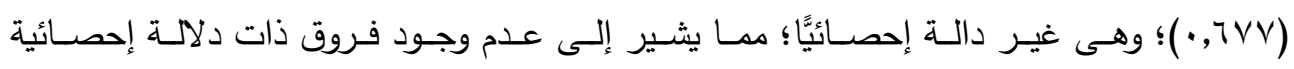

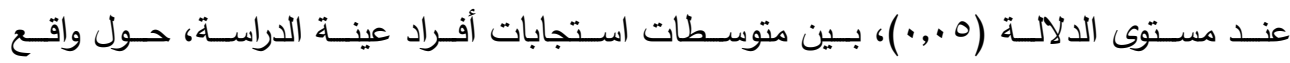

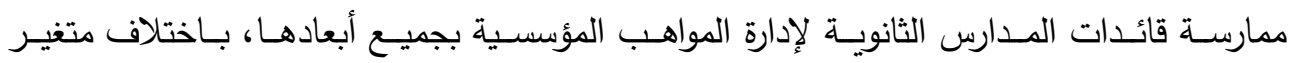

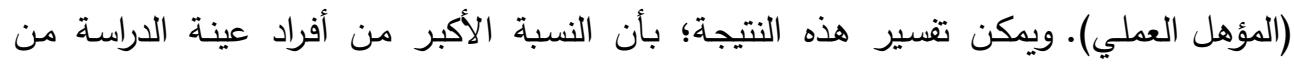

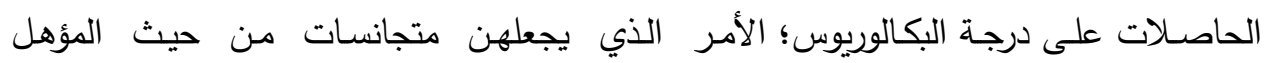

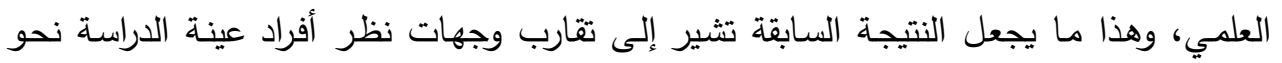
واقع ممارسة إدارة المواهب المؤسسية لدى قائدات المدارس الثانوية بمنطقة جازان.

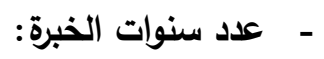

جدول رقم (†): نتائج تحليل التباين الأحادي،للفروق بين متوسطات استجابات أفراد عينة

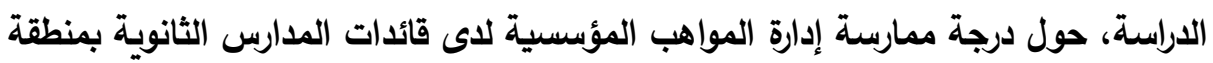
جازان، باختلاف متغير عدد سنوات الخبرة.

\begin{tabular}{|c|c|c|c|c|c|c|}
\hline مستوى الدلالة & قيمة & متوسط & الحربة & المربعات & مصدر التباين & الأبعاد \\
\hline
\end{tabular}




\begin{tabular}{|c|c|c|c|c|c|c|}
\hline \multirow{2}{*}{$\cdot, V Y}$. & \multirow{2}{*}{ תז, } & $\cdot, .0$ & r & $\cdot, 1$ & بين المجموعات & \multirow{2}{*}{ الدراهة الكلية لمحور درجة ممارسة إدارة } \\
\hline & &., 17 & TAV & $\leqslant 0, r q$ & داخل المجموعات & \\
\hline
\end{tabular}

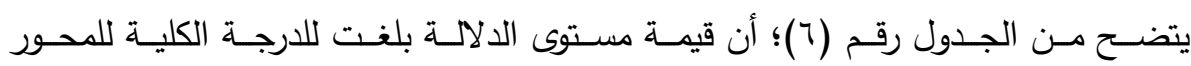

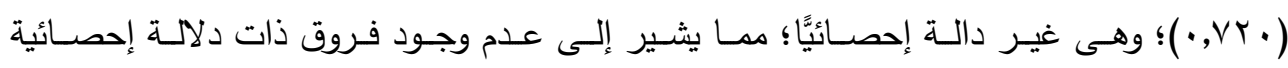

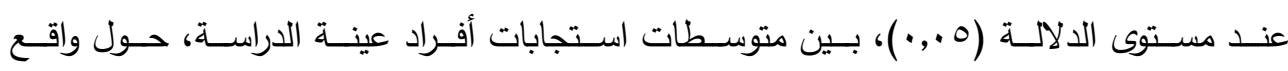

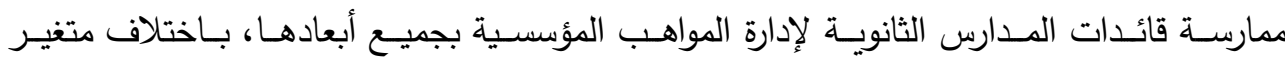

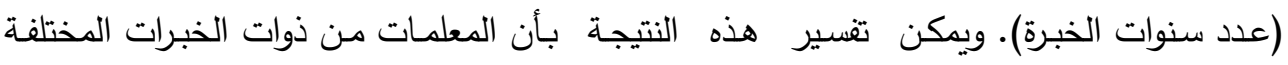

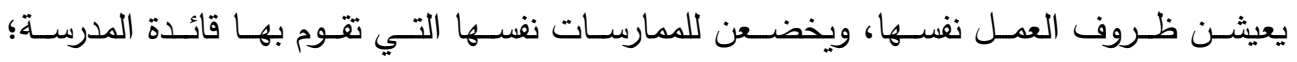
بغض النظر عن عدد سنوات الخبرة.

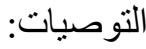

ا. إنثاء وحدة متخصصة بإدارة المواهب المؤسسية في إدارة التعليم، تتبعها لجان في المدارس،

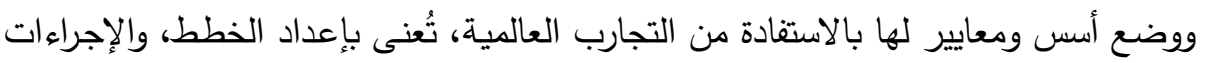

$$
\text { الخاصة بممارسة إدارة المواهب المؤسسية. }
$$

r. الاتجاه نحو ترسيخ ثقافة إدارة المواهب المؤسسية لاى قائدات المدارس بالمناطق المختلفة،

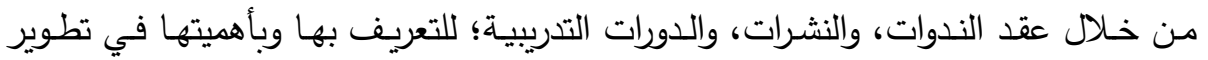
البيئة المدرسية، وتفعيل التقنية لخدمة هذا الأمر .

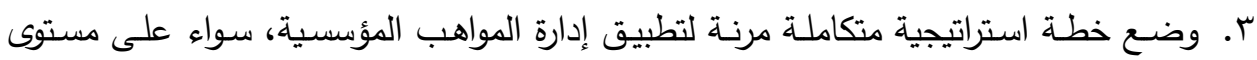
إدارة التعليم أو المدرسـة، يُثـارك فيهـا المعلمـات الموهوبـات وبعض الجهـات الاستثــارية والبحثية والمجتمعية، وتتضمّن أهدافًا وبرامج واقعية وقابلة للتطبيق.

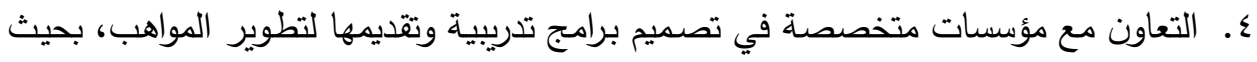

تقوم خطة التدريب التربوي وبرامجه على احتياجات التتمية المهنية للمعلمات بالمدرسة.

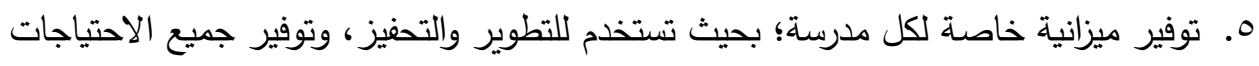

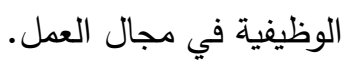

7. منح قائدات المدارس المزيـــ مـن الصـلاحيات التي تسـاعدهن على ممارسـة إدارة المواهب

$$
\text { المؤسسية. }
$$

V. تطوير معايير تقويم أداء المعلمات وتحفيزهن لتشمل: الموهبة، والقدرة الإبداعية، والإنتاج

$$
\text { النوعي لا الكمي. }
$$


^. ضرورة الالتزام بالتقويم الدوري لأداء المعلمات، واستخدام نتائجه في صياغة خطط المدرسة

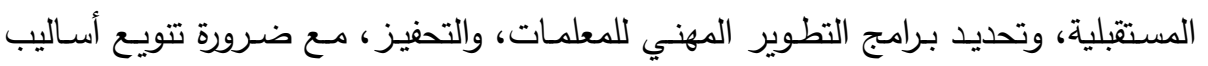

$$
\text { المقترحات : التقويم. }
$$

ا. إجراء دراسة بعنوان: بناء تصوّر مُقترح لممارسة إدارة المواهب المؤسسية في مدارس التعليم

$$
\text { العام. }
$$

r. القيام بدراسة بعنوان: مُعوقات ممارسة قائدات مدارس التعليم العام لإدارة المواهب المؤسسية. r. عمل دراسة بعنوان: مُتطلبات ممارسة قائدات مدارس التعليم العام لإدارة المواهب المؤسسية. ع. إجراء دراسة بعنوان: أثر المناخ التتظيمي في إدارة المواهب المؤسسية بمدارس التعليم العام. ه. إجراء دراسة بعنوان: دور إدارة المواهب المؤسسية في دعم الإبداع بمدراس التعليم العام. قائمة المر اجع المر اجع العربية:

أبو الجدائل، حاتم بن صلاح(ب ا • rم). إدارة المواهب .. نحو نموذج منهجي متكامل لعملية إدارة

$$
\text { المواهب، (ط ()، القاهرة، مركز الخبرات المهنية للإدارة "بميك". }
$$

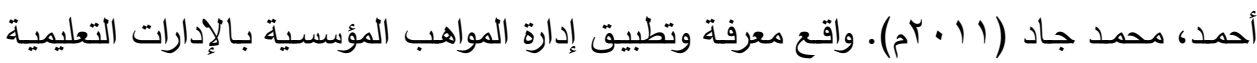

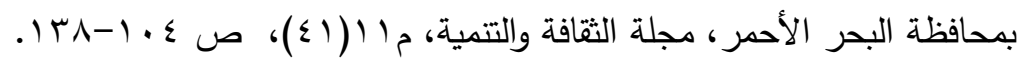

الجحدلي، غادة بنت عبد الحميد حميدان(؟ ؟ ا هـ). واقع إسهام إدارة المواهب في تتمية الموارد البشرية الأكاديمية بجامعة الملك عبد العزيز بجدة من وجهة نظر القيادات الجامعية بها، رسالة ماجستير (غير منشورة). جامعة أم القرى، كلية التربية، قسم الإدارة التربوية والتخطيط. مكة المكرمة.

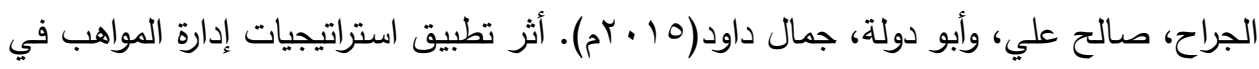
تعزيز الانتماء التتظيمي لدى أعضاء هيئة التدريس في الجامعات الأردنية الرسمية، المجلة

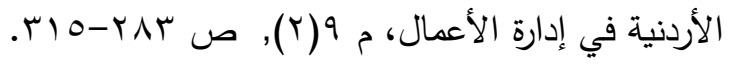

جمعة، محمود حسن (10 • rم). الأنماط القيادية ودورها في تطبيق نظام إدارة المواهب البشرية:

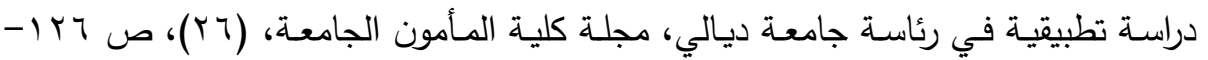


حاجم، ستار كاظم(r ا • rم). دور أبعاد إدارة الموهبة في دعم الإبداع في المنظمات التعليمية:

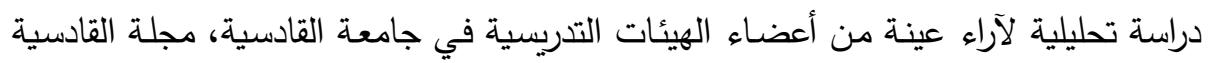

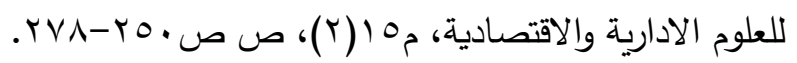

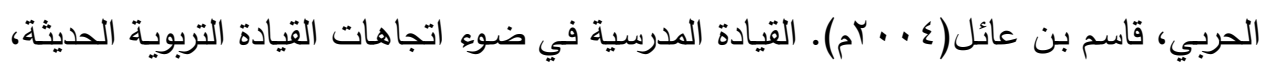
(ط ا)، الرياض، مكتبة الرشد ناشرون.

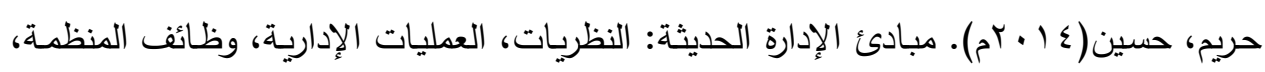

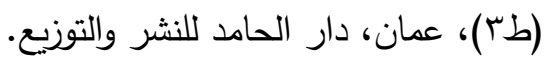

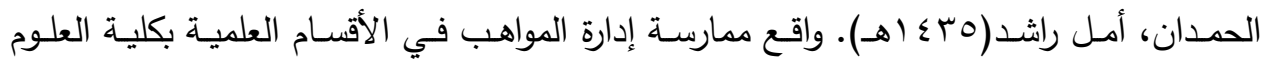

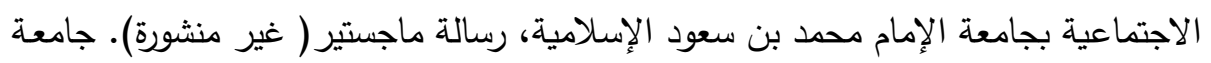
الإمـام محمد بن سعود الإسـلامية، كلية العلوم الاجتماعية، قسم الإدارة والتخطيط التربوي. الرياض.

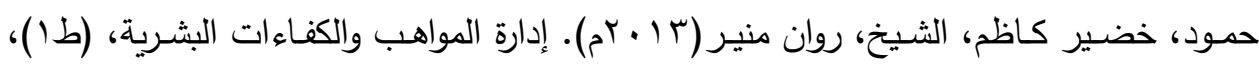
عمان، زمزم ناشرون وموزعون.

الخاطر، فايز (• ( •ام). استراتيجية التدربب الفعال، (ط ا)، عمان، دار أسامة للنشر والتوزيع.

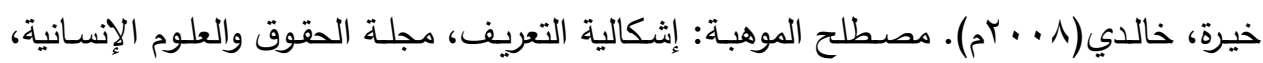

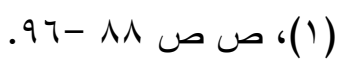
خيري، اسامة محمد(r ( • rج). إدارة الإبداع والابتكارات، (ط )، عمان، دار الراية للنشر والتوزيع.

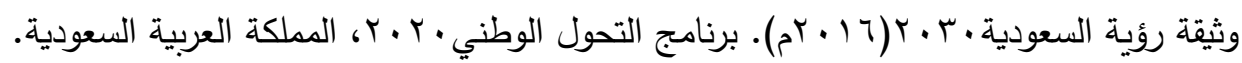

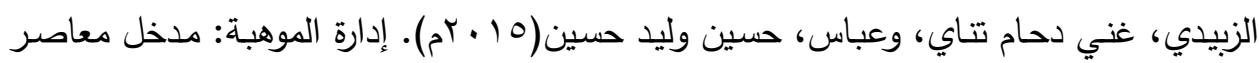
لإدارة الموارد البشرية، (ط ا)، عمان، دار الحامد للنشر والتوزيع.

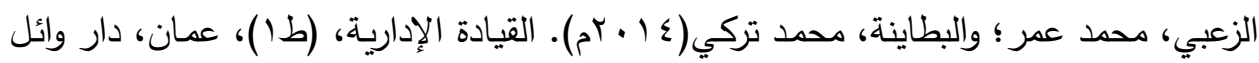
للنشر والتوزيع. محثب. الساعدي، مؤيد نعمة الساعدي(| (1 • rم). مستجدات فكرية معاصرة في السلوك التتظيمي وإدارة

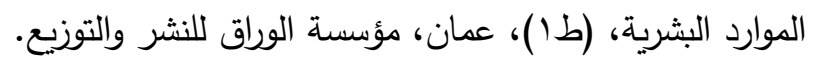

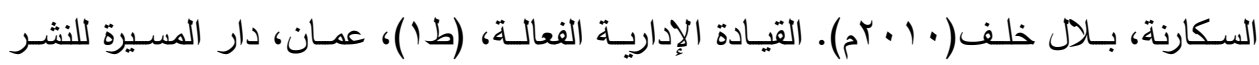
والتوزيع. 


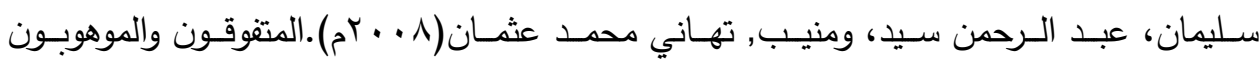
والمبتكرون،(ط ()،القاهرة، مكتبة الأنجلو المصرية.

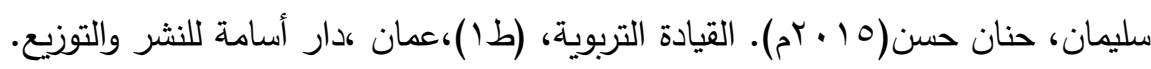

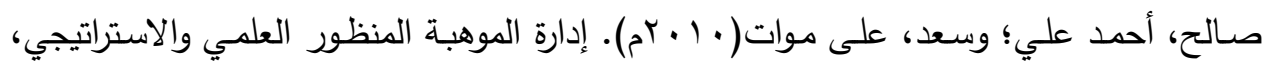

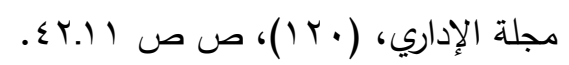

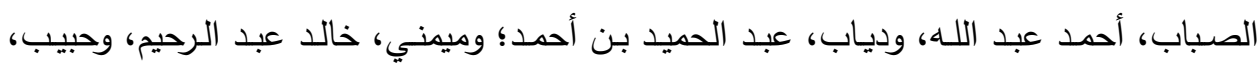

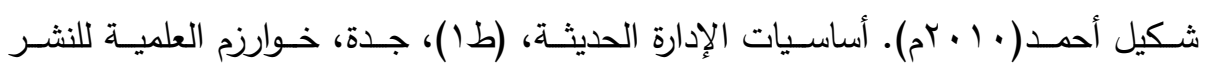
والتوزيع.

صيام، عزيزة عبد الرحمن، (r ( • rم)، واقع تطبيق نظام إدارة المواهب البشرية من وجهة نظر

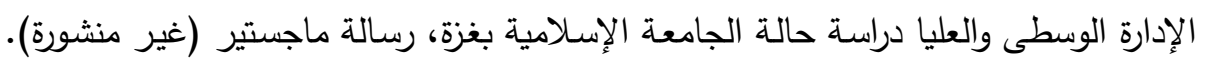

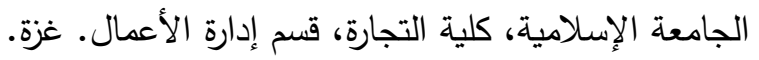

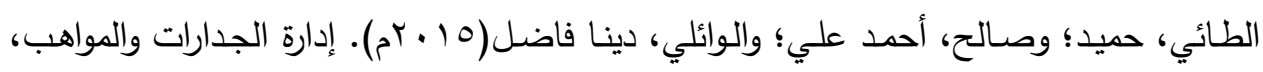
(طץ). عمان، دار اليازوري العملية للنشر والتوزيع.

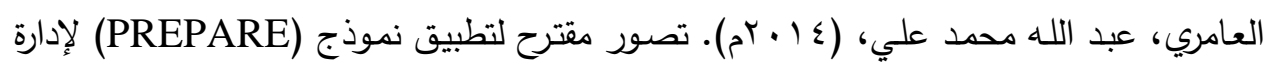
وتتمية المواهب القيادية في المؤسسات الحكومية بالمملكة العربية السعودية. مؤتمر القيادات

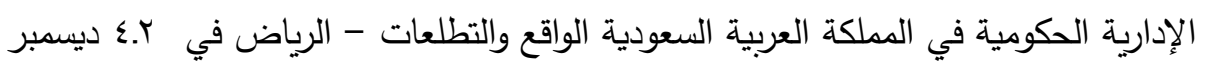

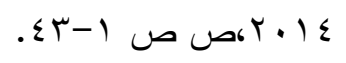

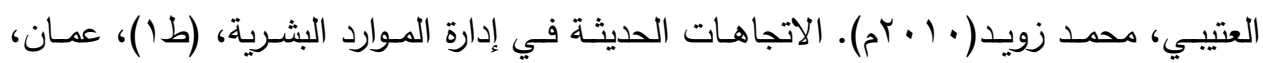

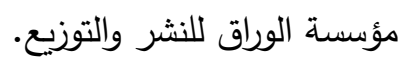
العنزي، سعد علي؛ والعطوى، عامر علي، والعابدي، علي رزاق( (1 لـ ام). أنظمة عمل الأداء

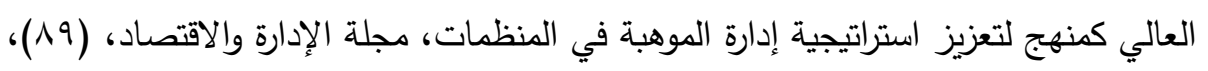
ص ص1 $91.0-1.0$

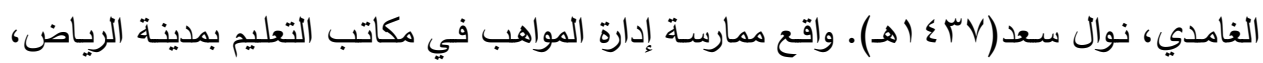

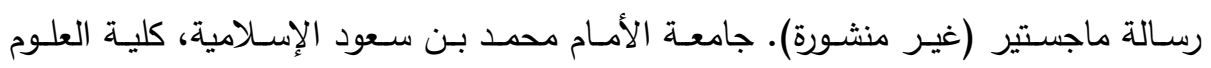
الاجتماعية، قسم الإدارة والتخطيط التربوي. الرياض. 


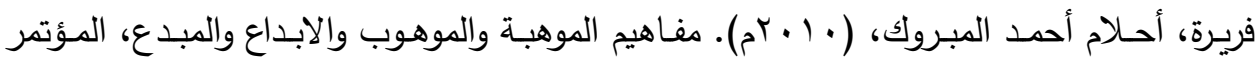

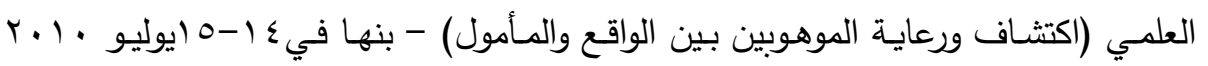

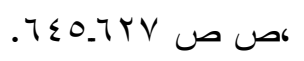

القحطاني، محمد دليم (r ( • ؟م). إدارة الموارد البشرية نحو منهج استراتيجي متكامل، (ط؟)،

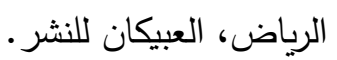

قنديل، علاء(• ( •rم). القيادة الإدارية وإدارة الابتكار ، (ط ا)، عمان، دار الفكر للنشر والتوزيع.

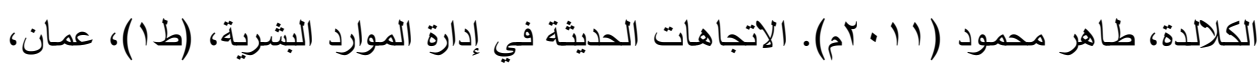
دار اليازوري العلمية للنشر والتوزيع.

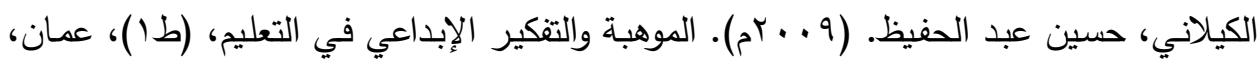
دار دجلة ناشرون وموزعون.

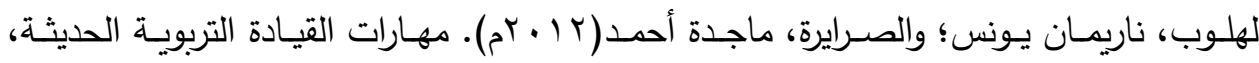

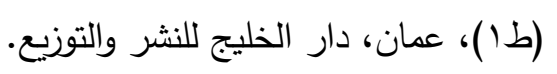

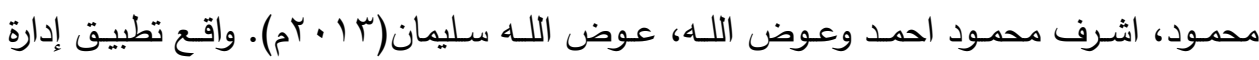
المواهب المؤسسية وعلاقتها بتمكين العاملين بمدارس التعليم العام بمحافظة الطائف، دراسات

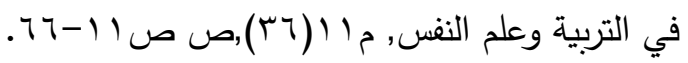

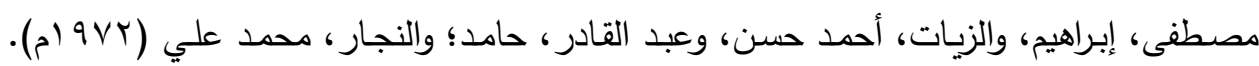
المعجم الوسيط، (طب), تركيا، المكتبة الإسلامية للطباعة والنشر والتوزيع.

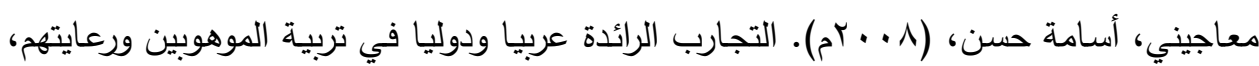
دراسة نظرية مسحية. المؤتمر السادس لوزراء التربية والتعليم العرب رعاية الموهوبين (خيار

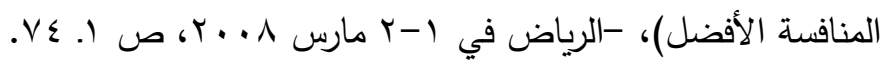

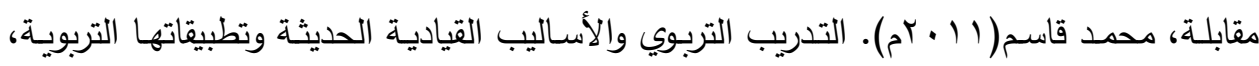
(ط (1) ,عمان، دار الثروق للنشر والتوزيع.

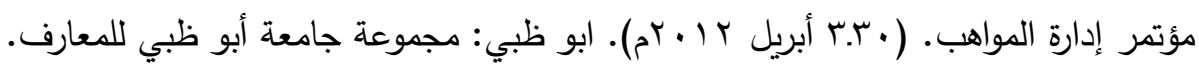

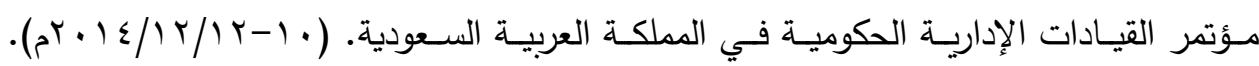
الرياض: معهد الادارة العامة.

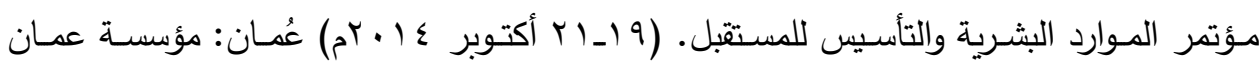
للصحافة والنشر والإعلان. 
المؤتمر والمعرض الدولي للتدريب والتطوير • (9 ــ إ أكتوبر 10 • بم). الرياض: جامعة الأميرة

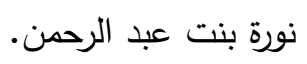

ناصـف، مرفت صـالح وزنـاتي، أمـل محسوب(1 ـ . بـم). إدارة المواهب مدخل لتفعيل الانتمـاء

التظيمي لأعضاء هيئات التدريس بالجامعات المصرية. دراسات في التعليم الجامعي، (9 (1), . ص ص

النعيمي، شهرزاد محمد شهاب موسى( • • بم). بناء برنامج تطويري في ضوء تقويم اداء مهارات

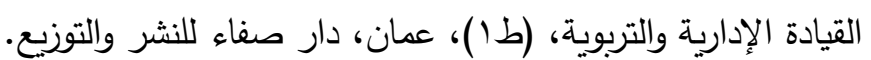

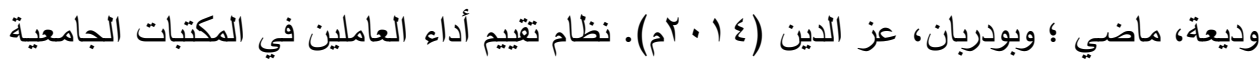

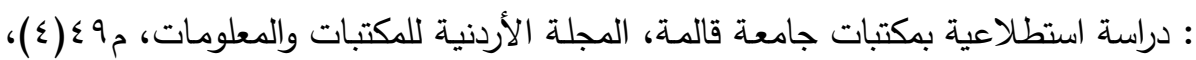

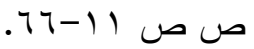

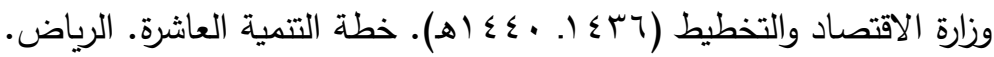

وزارة التعليم (VT\& اهـ). الدليل التظظيمي لمدارس التعليم العام، الإصدار الثالث. الرياض.

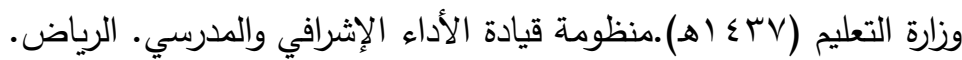

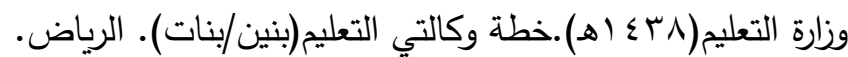

ثانيًا: المر اجع الأجنبية: المانية

Butterfield, B. (2008). Talent Management Strategies for Attracting and Retaining The Best and The Brightest, College and University Professional Association for Human Resources. Human Resources Journal, 59 ( 1), p.p. 33-38.

Chandra ,G.(2009). Human Resource management In WIHG. Unpublished master thesis. University of Ljubljana, Faculty of Economics. Slovenia.

Christensen, H. J.\& Rog, E. (2008). Talent management: A strategy for improving employee recruitment, retention and engagement within hospitality organizations. International Journal of Contemporary Hospitality Management,20(7),p.p. 743-757.

Dijk , H.G. van.(2008). The Talent Management approach to human resource management: attracting and retaining the right people, University of Pretoria. Journal of Public Administration, 43 (3), p.p. 385-395.

Kehinde, J. (2012).Talent Management: Effect on Organizational Performance. Journal of Management Research, 4(2), P.P. 178 - 186. 
Lewis, R. E. \& Heckman, R. J. (2006). Talent management: A critical review. journal Human Resource Management Review, 16(2),p.p. 139154.

Moghtadaie, L., \&Taji, M. (2016). Study of the performance of faculty members according to talent management approach in higher education. Educational Research and Reviews, 11(8), p.p. 781-790.

Ramadan, W. H. (2012). The Influence of Talent Management on Sustainable Competitive Advantage of Small and Medium Sized Establishments. E-Leader Berlin, P.P1-15.

Riccio,S.(2010).Talent Management in Higher Education: Developing Emerging Leaders Within the Administration at Private Colleges and Universities. Unpublished Doctor theses. Educational Administration. University of Nebraska. Lincoln.

Smith, A. B.; Wellins, R. S. and Paese, M. J. (2011). The CEO'S Guide to: Talent Management: A Practical Approach, DDIO:The Talent Management Expert.

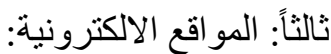

عبد الفتاح، علاوي (V . . rم). التطوير التظيمي والاستثمار في الكفاءات ودورها في التغيير

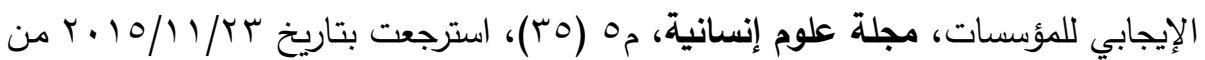

hوقع: موقيج

العديلي، ناصـر محمد(9 . rم).كيف هي حال إدارة الموهبة في الثركات السعودية؟، جريـدة

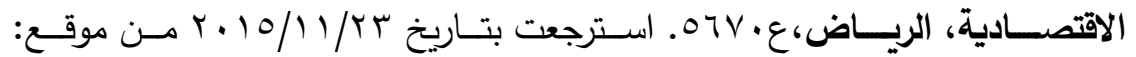

http://cutt.us/lwddN

William, A. (2006) . Talent Management. Ph.D Thesis. Innovations International, Inc, Salt 